UNIVERSIDADE DE SÃO PAULO

FACULDADE DE FILOSOFIA CIÊNCIAS E LETRAS DE RIBEIRÃO PRETO

DEPARTAMENTO DE PSICOLOGIA

PROGRAMA DE PÓS-GRADUAÇÃO EM PSICOLOGIA

\title{
Reabilitação Psicossocial e Estratégia Saúde da Família: Desafios no cuidado à saúde mental
}

\author{
MARA SOARES FRATESCHI
}

Dissertação apresentada à Faculdade de Filosofia, Ciências e Letras de Ribeirão Preto da Universidade de São Paulo como parte das exigências para obtenção do título de Mestre em Ciências.

Área de Concentração: Psicologia.

Apoio: FAPESP 

UNIVERSIDADE DE SÃO PAULO

FACULDADE DE FILOSOFIA CIÊNCIAS E LETRAS DE RIBEIRÃO PRETO

DEPARTAMENTO DE PSICOLOGIA

PROGRAMA DE PÓS-GRADUAÇÃO EM PSICOLOGIA

\title{
Reabilitação Psicossocial e Estratégia Saúde da Família: Desafios no cuidado à saúde mental
}

\author{
Mara Soares Frateschi \\ Orientadora: Professora Doutora Cármen Lúcia Cardoso
}

Dissertação apresentada à Faculdade de Filosofia Ciências e Letras de Ribeirão Preto da Universidade de São Paulo, como parte das exigências para obtenção do título de Mestre em Ciências.

Área de Concentração: Psicologia.

Apoio: FAPESP

\section{Ribeirão Preto}


Autorizo a reprodução e divulgação total ou parcial deste trabalho, por qualquer meio convencional ou eletrônico, para fins de estudo e pesquisa, desde que citada a fonte.

FICHA CATALOGRÁFICA

Frateschi, Mara Soares

Reabilitação Psicossocial e Estratégia Saúde da Família: desafios no cuidado à saúde mental. Ribeirão Preto, 2014.

189 p. : il. ; $30 \mathrm{~cm}$

Dissertação de mestrado apresentada à Faculdade de Filosofia, Ciências e Letras de Ribeirão Preto/USP. Área de Concentração: Psicologia.

Orientadora: Cardoso, Cármen Lúcia.

1. Estratégia Saúde da Família. 2. Atenção Primária à Saúde.

3. Saúde Mental. 4. Reabilitação Psicossocial. 


\section{FOLHA DE APROVAÇÃO}

Frateschi, Mara Soares

Reabilitação Psicossocial e Estratégia Saúde da Família: Desafios no cuidado à saúde mental.

Dissertação apresentada à Faculdade de Filosofia Ciências e Letras de Ribeirão Preto da Universidade de São Paulo, como parte das exigências para obtenção do título de Mestre em Ciências.

Área de Concentração: Psicologia.

Aprovado em:

l

l

\section{Banca Examinadora}

Prof. Dr.

Instituição: Julgamento:

Assinatura:

Prof. Dr.

Instituição: Julgamento:

Assinatura:

Prof. Dr.

Instituição: Julgamento:

Assinatura: 

À minha família e ao Alexandre, pela presença e incentivo nesta caminhada.

A todos que participaram deste estudo ou que de alguma forma se identificam com ele. 



\section{AGRADECIMENTOS}

Aos participantes deste estudo, profissionais da Estratégia Saúde da Família, usuários e seus familiares, que interromperam suas tarefas cotidianas para compartilhar suas experiências com relação aos cuidados em saúde mental.

Às duas Unidades de Saúde da Família em que a pesquisa foi realizada, pelo acolhimento e por disponibilizarem o espaço das Unidades para realização do trabalho.

À Cármen, minha orientadora, pela competência e comprometimento e, principalmente, pelo afeto e pela parceria. Cármen, sou muito grata por ter podido caminhar ao seu lado durante esses anos. Obrigada por me possibilitar tanto crescimento!

Aos meus pais, Rogéria e Paulo Henrique, por estarem sempre ao meu lado, me acompanhando e incentivando mesmo que falemos idiomas diferentes. Pai, Mãe, mesmo a laje do baldrame sendo de concreto armado, o pé direito é suficiente quando o macadame é hidráulico. Acertei? Bem, eu quis dizer em "engenheirês” que não cabe em palavras o quanto é bom ter vocês por perto! Obrigada por toda a dedicação a mim, à Paula e ao Lelê, e por fazerem da nossa casa um lugar tão gostoso de estar.

Aos meus irmãos, Paula e Alexandre, por me ensinarem a amar e a brigar. Por dividirem comigo os pais, a infância, a casa e a vida. Pela certeza de que estão constantemente perto de mim e de que ainda temos muitos bons momentos a compartilhar...

À minha grande família, avós, tios, primos e agregados, sogros e cunhados, por estarem sempre incrivelmente presentes apesar de eventuais distâncias. Saber que eu carrego "tanta diferente gente" comigo é muito confortante.

Em especial, à minha avó Edméia, que me presenteou com o patchwork que ilustra a capa deste trabalho; que sempre produziu coisas belas alinhavando os retalhos vida e, atualmente, tem feito o mesmo com pequenos pedaços de pano. Ao meu primo Gabriel, por me emprestar seu senso estético e me ajudar com a preparação da capa.

Ao Alexandre, por tanta coisa! Pelo carinho, pela paciência, pela prontidão de sempre. Pela tranquilidade de tê-lo por perto. Pelas contribuições para este trabalho. 
Às minhas amigas, especialmente Marcella, Juliana, Vanessa, Isabella e Daniela, pela presença, ainda que inconstante. Por me levarem com elas e por se deixarem comigo.

À $43^{\mathrm{a}}$ turma de Psicologia da Faculdade de Filosofia, Ciências e Letras de Ribeirão Preto, pelos anos de formação compartilhados.

À Ângela, por percorrer comigo meus caminhos.

Às professoras Toyoko Saeki e Roseli Vernasque Bettini, pelas contribuições oferecidas durante a qualificação deste trabalho.

À Faculdade de Filosofia, Ciências e Letras de Ribeirão Preto (FFCLRP-USP), e todos os seus funcionários e professores, pela estrutura disponibilizada para a realização e conclusão deste trabalho.

À Prefeitura Municipal de Ribeirão Preto, pela coparticipação neste estudo.

À Fundação de Amparo à Pesquisa do Estado de São Paulo pelo apoio financeiro. 


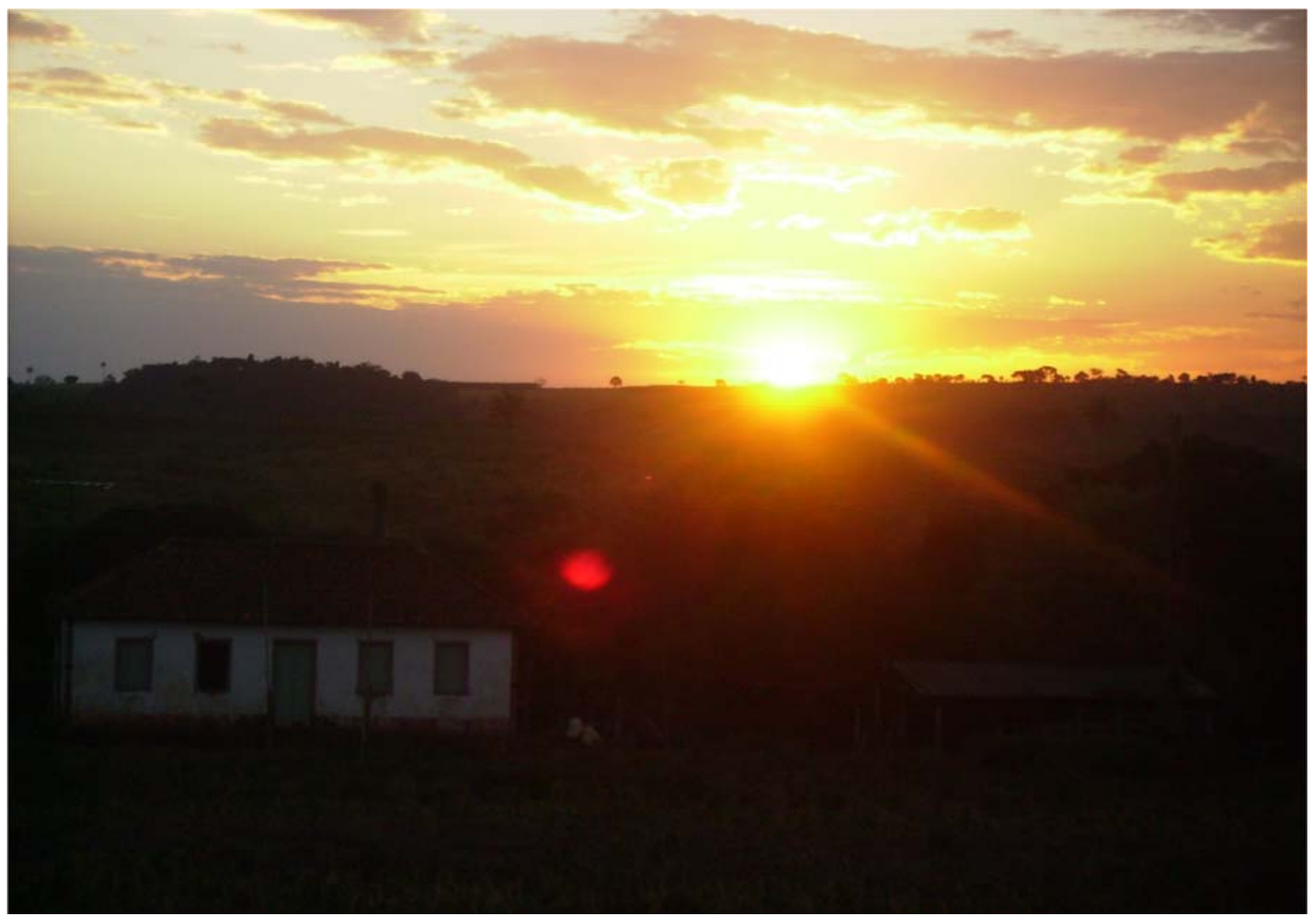

Tecendo a manhã

Um galo sozinho não tece uma manhã: ele precisará sempre de outros galos. De um que apanhe esse grito que ele e o lance a outro; de um outro galo que apanhe o grito de um galo antes e o lance a outro; e de outros galos que com muitos outros galos se cruzem os fios de sol de seus gritos de galo, para que a manhã, desde uma teia tênue, se vá tecendo, entre todos os galos.

E se encorpando em tela, entre todos, se erguendo tenda, onde entrem todos, se entretendendo para todos, no toldo (a manhã) que plana livre de armação. A manhã, toldo de um tecido tão aéreo que, tecido, se eleva por si: luz balão.

(João Cabral de Melo Neto) 



\section{RESUMO}

Frateschi, M. F. (2014). Reabilitação Psicossocial e Estratégia Saúde da Família: Desafios no cuidado à saúde mental. Dissertação de Mestrado, Departamento de Psicologia, Faculdade de Filosofia Ciências e Letras de Ribeirão Preto, Universidade de São Paulo.

A Estratégia Saúde da Família (ESF) tem se destacado como uma importante alternativa para a (re)inserção da pessoa em sofrimento mental na sociedade, em conformidade com a Reforma Psiquiátrica. A Reabilitação Psicossocial é compreendida como uma abordagem que visa a emancipação da pessoa, a redução da discriminação, a valorização das capacidades individuais e sociais e a criação de um sistema de apoio de longa duração. Este estudo objetivou conhecer e compreender as ações desenvolvidas pela ESF no que se refere à Reabilitação Psicossocial em saúde mental, a partir da perspectiva dos profissionais, usuários e familiares. A coleta de dados foi realizada em duas Unidades de Saúde da Família (USF) de Ribeirão Preto-SP e os participantes foram 26 profissionais, 3 usuárias e 2 familiares. Os instrumentos utilizados para a coleta foram a entrevista individual aberta e a observação participante. O material foi submetido à análise seguindo a abordagem qualitativa e utilizouse como ferramenta a Análise de Conteúdo Temática. A análise possibilitou a construção de seis categorias temáticas, a saber: 1) "Contextos e relações: Necessidades apontadas como sendo o motivo pela procura por ajuda na USF”; 2) “Ações: o desafio de cuidar da saúde mental no território"- indica as ações desenvolvidas pelas USFs, ou seja, estratégias tradicionais, escuta qualificada, cuidado longitudinal, trabalho em equipe e estratégias coletivas; 3) "O contato com o sofrimento mental e o preparo para o trabalho: caminhos para a transformação das práticas" - sugere que o olhar para a pessoa em sofrimento mental, em sua múltipla e complexa existência, oportuniza transformações das práticas por meio da desmistificação da loucura; 4) "Dificuldades encontradas no processo de cuidado da saúde mental" - aponta a falta de preparo técnico e psicológico, o excesso de demanda e a insuficiência da rede, como possíveis entraves dos processos de trabalho; 5) "Avaliação do cuidado ofertado em saúde mental pelas USFs” - indica que, numa perspectiva clínica tradicional, os serviços foram considerados efetivos e adequados, entretanto, os entrevistados evidenciaram um processo de transformação das práticas, indicando a necessidade de avançar em estratégias psicossociais; 6) "Transformações do cuidado em saúde mental: Concepções dos participantes acerca da pessoa em sofrimento mental e da viabilização da desinstitucionalização e da Reabilitação Psicossocial” - aborda os significados atribuídos pelos entrevistados ao sofrimento mental e aos processos de cuidado, indicando que tais compreensões interferem nas práticas e posturas instituídas. Os resultados apontaram que o sofrimento mental é correlato ao contexto e às relações estabelecidas pelas pessoas. Destacase que os serviços estão avançando em direção a estratégias mais dialógicas e espontâneas, todavia, estas ainda são colocadas em prática de forma individual. Conclui-se que o processo de transformação das práticas é lento e implica a superação de "armadilhas” cotidianas que dificultam o investimento em ações que transcendam as estratégias tradicionais, avançando para o coletivo, buscando novas formas de pensar e fazer saúde. Neste sentido, este estudo traz avanços relativos à viabilização das práticas de cuidado em saúde mental no território visando o comprometimento com a pessoa em seu percurso de vida.

Palavras-chave: Estratégia Saúde da Família; Atenção Primária à Saúde; Saúde Mental; Reabilitação Psicossocial. 



\begin{abstract}
Frateschi, M. F. (2014). Psychosocial Rehabilitation and Family Health Strategy: Challenges in mental health care. Dissertação de Mestrado, Departamento de Psicologia, Faculdade de Filosofia Ciências e Letras de Ribeirão Preto, Universidade de São Paulo.

The Family Health Strategy (FHS) has stood out as an important alterative for (re)inserting people in mental suffering into society, in accordance with the Brazilian Psychiatric Reform. Psychosocial rehabilitation is understood as an approach aiming at the subject's emancipation, reduction of discrimination, appreciation of individual and social capabilities and the creation of a long-term support system. The objective of this study was to learn and understand the actions developed by the FHS in terms of psychosocial rehabilitation in mental health, from the perspective of professionals, users and families. Data were collected from two Family Health Units (FHUs) in Ribeirão Preto, São Paulo state, and study participants were 26 professionals, 3 users and 2 family members. Open individual interviews and participant observation were the instruments used for data collection. The material was submitted to analysis following the qualitative approach, and the Thematic Content Analysis was used. The analysis allowed for the construction of six categories, namely: 1) "Contexts and relationships: Needs pointed as being the reason for reaching the FHS for help"; 2) "Actions: the challenge of delivering mental health care in the unit's territory"- indicating the actions developed by the FHUs, that is, traditional strategies, qualified listening, longitudinal care, teamwork, and collective strategies; 3) "The contact with mental suffering and the training for this work: paths to transform the practices" - suggesting that looking at the person in mental suffering, in his/her multiple and complex existence, enables transformations in the practices by demystifying madness; 4) "Difficulties found in the mental health care process" - pointing to the lack of technical and psychological preparation, the excessive demand and the insufficient network as possible hindrances in the work processes; 5) "Evaluation of the mental health care provided by the FHUs" - indicating that, from a traditional clinical perspective, the services were considered effective and appropriate, however, the interviewees evidenced a process of transformation of the practices, demonstrating the need for making progress in psychosocial strategies; 6) "Transformations in mental health care: Conceptions of the participants regarding the person in mental suffering and the process of making deinstitutionalization and psychosocial rehabilitation feasible" - approaching the meanings attributed by the interviewees to mental suffering and to the care processes, showing that such understandings interfere in the established practices and conducts. The results showed that mental suffering is correlated to the context and to the relationships established among people. Services are advancing towards more dialogical and spontaneous strategies, however, these strategies are still placed into practice individually. In conclusion, the process of transforming practices is slow and implies overcoming the daily "traps" that make it difficult to invest in actions that transcend traditional strategies, advancing towards the collective and searching for new ways of thinking and doing health. In this sense, this study provides progress regarding the feasibility of care practices in mental health in the territory of FHUs, aiming at committing to people throughout their life journey.
\end{abstract}

Keywords: Family health strategy; Primary health care; Mental health; Psychosocial rehabilitation. 



\section{LISTA DE FIGURAS}

Figura 1 - Critérios de inclusão dos participantes 54

Figura 2 - Descrição dos profissionais entrevistados das Unidades A e B, de acordo com idade, profissão e tempo de atuação 56

Figura 3 - Descrição dos usuários e familiares entrevistados das Unidades A e B, de acordo com idade, e grau de parentesco 58

Figura 4 - Categorias temáticas e subcategorias correspondentes 69 



\section{LISTA DE SIGLAS}

ACS - $\quad$ Agente Comunitário de Saúde

APAE - $\quad$ Associação de Pais e Amigos dos Excepcionais

CAAE - Certificado de Apresentação para Apreciação Ética

CAPS - C Centro de Atenção Psicossocial

ESF - $\quad$ Estratégia Saúde da Família

MTSM - $\quad$ Movimento dos Trabalhadores de Saúde Mental

NASF - N Núcleo de Apoio à Saúde da Família

ONG - Organização Não Governamental

PSF - $\quad$ Programa de Saúde da Família

SMS - $\quad$ Secretaria Municipal de Saúde

SUS - $\quad$ Sistema Único de Saúde

TCLE - Termo de Consentimento Livre e Esclarecido

UBDS - $\quad$ Unidade Básica Distrital de Saúde

UBS - $\quad$ Unidade Básica de Saúde

USF - $\quad$ Unidade de Saúde da Família

USFs - $\quad$ Unidades de Saúde da Família

USP - $\quad$ Universidade de São Paulo 



\section{SUMÁRIO}

APRESENTAÇÃO .................................................................................................................... 25

1 INTRODUÇÃO ........................................................................................................... 31

1.1 Transformações do Modelo Assistencial em Saúde................................................................. 31

1.2 Estratégia Saúde da Família (ESF)................................................................................... 33

1.3 Reabilitação Psicossocial em saúde mental: aspectos histórico-sociais e o cenário

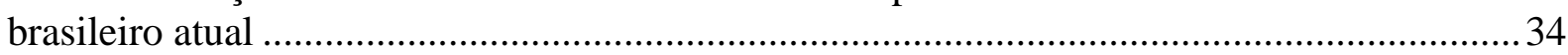

2 OBJETIVOS …..........................................................................................................4

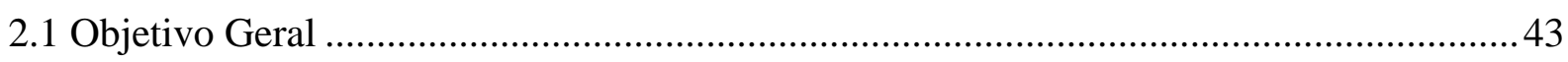

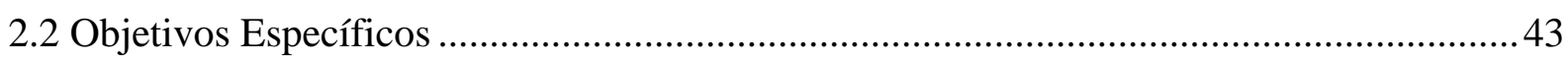

3 JUSTIFICATIVA DO ESTUDO.............................................................................................47

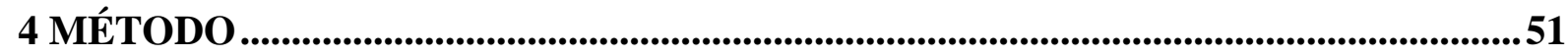

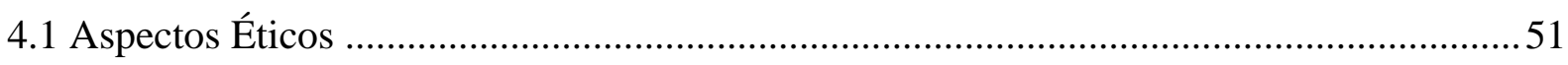

4.2 Caracterização da Situação de Estudo .............................................................................51

4.3 Escolha das Unidades de Saúde da Família ....................................................................52

4.4 Contato com as Unidades de Saúde da Família..................................................................53

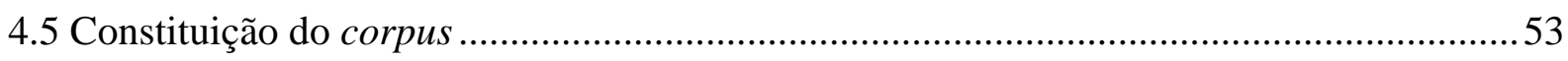

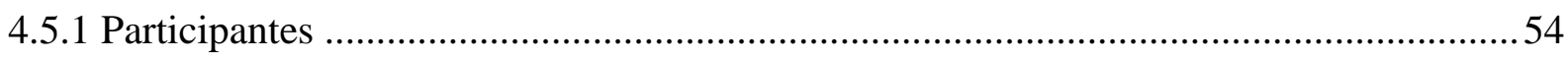

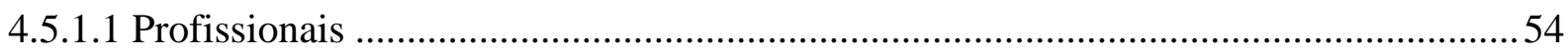

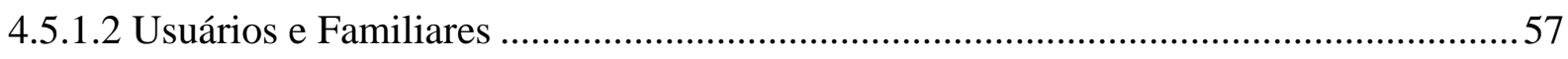

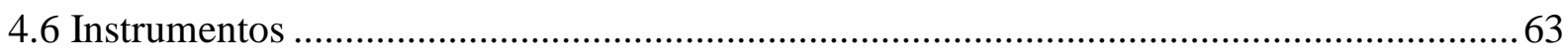

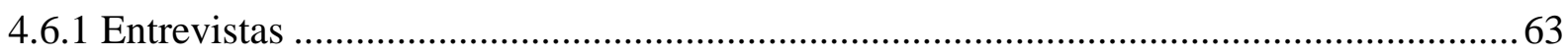

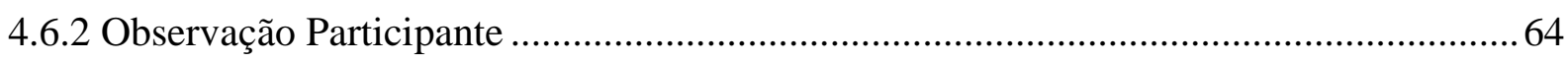

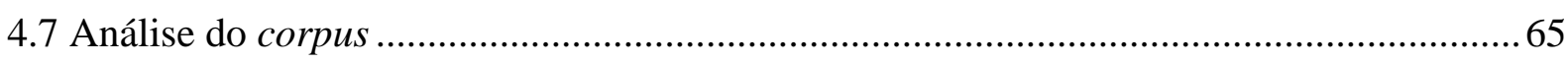

5 RESULTADOS E DISCUSSÃO .........................................................................67

5.1 Contextos e relações: Necessidades apontadas como sendo o motivo pela procura por ajuda na USF ...........................................................................................................

5.2 Ações: o desafio de cuidar da saúde mental no território .....................................................79 
5.2.1 Consultas, encaminhamentos, internações e medicamentos: o lugar das estratégias tradicionais na ESF

5.2.2 A escuta e a conversa como estratégias de promoção e preservação da saúde mental... 85

5.2.3 Vínculo e Cuidado Longitudinal....

5.2.4 O trabalho em equipe como ferramenta para o cuidado à saúde mental........................ 91

5.2.5 Desenvolvimento de estratégias coletivas e apropriação de espaços comunitários.....

5.3 O contato com o sofrimento mental e o preparo para o trabalho: caminhos para a

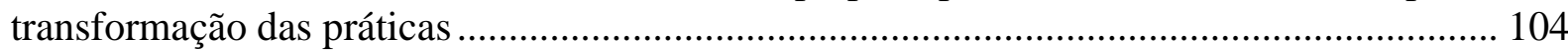

5.4 Dificuldades encontradas no processo de cuidado da saúde mental ................................ 109

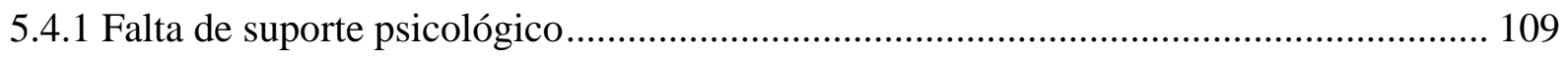

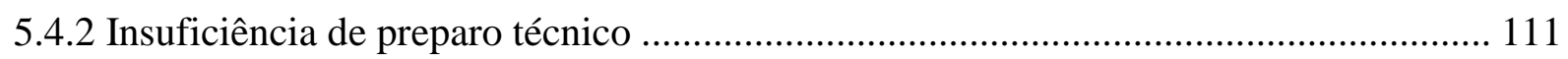

5.4.3 Dificuldade de organização dos processos de trabalho................................................. 113

5.4.4 Insuficiência e/ou desarticulação da rede................................................................... 119

5.5 Avaliação do cuidado ofertado em saúde mental pelas Unidades de Saúde da Família.. 124

5.6 Transformações do cuidado em saúde mental: Concepções dos participantes acerca da pessoa em sofrimento mental e da viabilização da desinstitucionalização e da Reabilitação

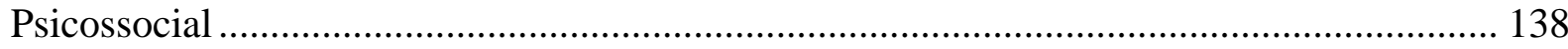

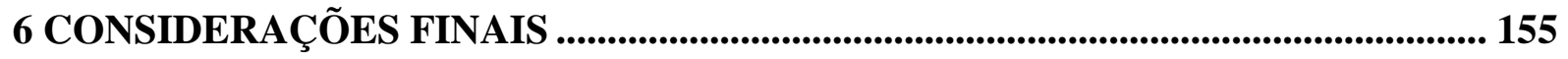

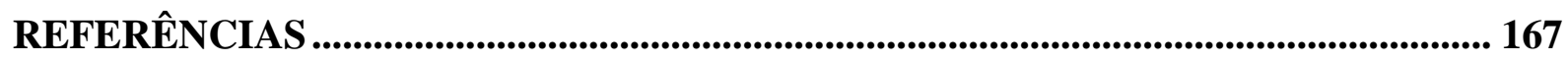

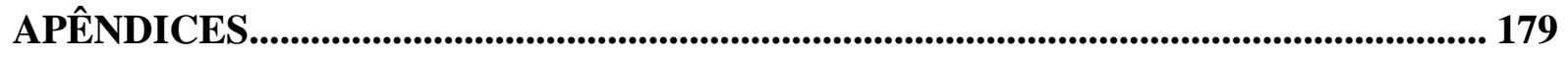

Apêndice A - Termo de Consentimento Livre e Esclarecido............................................... 179

Apêndice B - Roteiro Orientador da Entrevista com os Profissionais ................................. 181

Apêndice C - Roteiro Orientador da Entrevista com os Usuários........................................ 182

Apêndice D - Roteiro Orientador da Entrevista com os Familiares...................................... 183

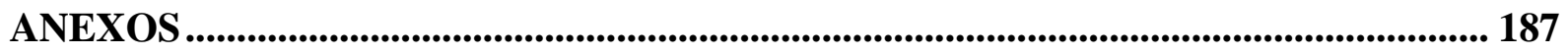

Anexo A - Ofício de manifestação de concordância da instituição coparticipante (Secretaria Municipal de Saúde de Ribeirão Preto) ............................................................. 187

Anexo B - Parecer consubstanciado do Comitê de Ética em Pesquisa da FFCLRP-USP .... 188 
APRESENTAÇÃO 



\section{APRESENTAÇÃO}

Meu interesse por estudar o cuidado em saúde mental ofertado pela Atenção Primária à Saúde teve início durante a graduação, quando tive oportunidade de me aproximar do tema por meio de disciplinas, estágios curriculares e, também, através de espaços de discussão e formação fora das salas de aula.

Disciplinas como "Psicologia e Saúde”, ministrada pela professora Cármen Lúcia Cardoso e "Organização do Trabalho e Saúde do Trabalhador”, oferecida pelo professor Marco Antônio de Castro Figueiredo, foram marcantes enquanto oportunidades de ampliação do olhar para a área da saúde. Por meio de visitas a diferentes serviços de saúde, de entrevistas a profissionais e de leituras, pude compreender melhor o Sistema Único de Saúde e suas estratégias de intervenção e me aproximar das questões associadas ao conceito de saúde e suas implicações práticas no cotidiano do serviço.

Nos anos de 2007 e 2008, participei da Liga de Saúde Mental promovida pelo Centro Acadêmico da Faculdade de Medicina de Ribeirão Preto (FMRP- USP). A Liga promovia encontros semanais entre alunos dos cursos de Psicologia, Medicina e Terapia Ocupacional visando a discussão de temas relacionados à saúde mental, frequentemente com a participação de convidados atuantes na área. Também eram realizadas observações de plantões no setor de Psiquiatria da Unidade de Emergência do Hospital das Clínicas da FMRP. Tais atividades possibilitaram que eu entrasse em contato com o sofrimento mental, em geral, em situações de agudização, me aproximando da conduta médica diante de tais casos e desenvolvendo a minha compreensão acerca dos serviços que compõem a rede de cuidados em saúde mental e os caminhos percorridos pelos usuários.

Como membro do Centro Estudantil da Psicologia no período compreendido entre 2006 e 2009, pude participar de momentos de discussão e de formação entre os alunos. Buscávamos promover espaços de reflexão sobre temas pouco abordados pela grade curricular. Nessa perspectiva, participei ativamente da comissão organizadora dos eventos "I Encontro de Saúde Mental - A Loucura Desamarrada”, ocorrido em 2008, e "II Encontro de Saúde Mental - Como somos tratados?”, ocorrido em 2009. Estes eventos foram idealizados e organizados integralmente pelos estudantes, com a finalidade de discutir temas como a desinstitucionalização da assistência psiquiátrica, os serviços de saúde disponíveis para o cuidado em saúde mental e os caminhos percorridos pelos usuários através da rede de saúde. 
Durante o quarto ano da graduação, em 2009, realizei o estágio “O Psicólogo em uma Equipe do Programa de Saúde da Família: Desenvolvendo Programa de Saúde na Comunidade”, supervisionado pela professora Cármen Lúcia Cardoso e pela psicóloga Lícia Barcelos de Souza, realizado junto a uma Unidade de Saúde da Família (USF) da cidade de Ribeirão Preto. Durante este período, pude participar do cotidiano da equipe de saúde do serviço, conhecer a comunidade local e desenvolver estratégias de intervenção com foco nas necessidades da comunidade. Uma das atividades desenvolvidas, juntamente com as demais estagiárias, foi um grupo de mulheres, elaborado com a ajuda de alguns dos profissionais da equipe. Esta atividade foi proposta após observarmos uma grande quantidade de mulheres jovens, donas de casa, com filhos pequenos, recorrendo à Unidade de Saúde com queixas de solidão e entristecimento. O grupo objetivava reunir as mulheres da comunidade que se encaixavam no perfil descrito, a fim de que fosse construído um espaço de troca entre pessoas que viviam em condições semelhantes. Buscava-se, ainda construir e fortalecer o vínculo dessas mulheres com a equipe da USF. Esta experiência possibilitou um exercício de reflexão e questionamento acerca da conduta dos profissionais diante das demandas em saúde mental, bem como o desenvolvimento de estratégias de promoção de saúde na comunidade a partir da observação da demanda.

Ao final deste ano de estágio, procurei a professora Cármen a fim de continuar estudando a questão do cuidado em saúde mental no âmbito da Atenção Primária à Saúde. A partir dessa motivação e sob orientação da docente, desenvolvi minha Iniciação Científica durante os anos de 2010 e 2011, que resultou na monografia intitulada "Saúde Mental na Atenção Primária à Saúde: Avaliação sob a ótica de usuários”, cujo objetivo foi investigar a avaliação que os usuários fazem do cuidado em saúde mental oferecido por dois serviços públicos de saúde da Atenção Primária, a saber: uma Unidade Básica de Saúde tradicional e uma Unidade de Saúde da Família. Buscou-se ainda investigar expectativas, experiências e satisfação dos usuários com relação ao serviço que frequentavam. Concluiu-se, a partir deste trabalho, que a inserção de práticas voltadas para a saúde mental nos serviços da Atenção Primária ainda é um desafio. Os usuários se posicionaram criticamente frente à assistência recebida e apontaram a necessidade de uma escuta mais qualificada, que promova acolhimento e vínculo, bem como de uma assistência mais humanizada, longitudinal e integral. Nesse cenário, considera-se a avaliação feita pelos usuários como peça fundamental para o desenvolvimento de novas práticas de saúde, partindo das necessidades e expectativas da própria comunidade. Destaca-se que este estudo foi financiado pela Fundação de Amparo à Pesquisa do Estado de São Paulo (Processo FAPESP nº 2010/07143-3). 
Ressalta-se que os resultados deste trabalho culminaram na elaboração de um artigo científico homônimo da monografia, publicado pela revista Physis: Revista de Saúde Coletiva da Universidade Estadual do Rio de Janeiro. Os resultados também foram apresentados em diferentes eventos, incluindo congressos científicos e fóruns de discussão, tendo recebido "Homenagem pela relevante experiência de humanização nas práticas em saúde” no I Fórum Paulista de Humanização nas Práticas de Saúde: 25 anos SUS, realizado em novembro de 2013 em São Paulo/SP, e, prêmio de “Melhor Trabalho Científico” no II Congresso Internacional de Saúde Mental e Reabilitação Psicossocial, realizado em outubro de 2012 em Porto Alegre/RS.

No presente trabalho, busco conhecer e compreender as ações desenvolvidas pela Estratégia Saúde da Família no que se refere à Reabilitação Psicossocial em saúde mental. Considera-se que as práticas de cuidado em saúde mental são atravessadas por crenças, valores e opiniões atribuídos à pessoa em sofrimento mental e ao papel do serviço de saúde frente a esta demanda. Nesse sentido, torna-se relevante conhecer e compreender estas ações, empreendendo um exercício de reflexão e questionamento dos sentidos e significados que as sustentam, na tentativa de avançar nos processos de desmistificação do sofrimento mental e na construção de ações que respondam às necessidades dos usuários, seus familiares e da comunidade. Este estudo não tem como pretensão encontrar as respostas para as inquietações que o motivaram, mas, sim, provocar reflexões, ampliar as discussões e quiçá contribuir para a ampliação dos cuidados em saúde mental ofertados pela Estratégia Saúde da Família. 
INTRODUÇÃO 



\section{INTRODUÇÃO}

\subsection{Transformações do Modelo Assistencial em Saúde}

Na década de 70, as questões relativas à saúde passaram a ser amplamente debatidas em diferentes cenários e em nível internacional. Para discussão desta temática foram realizados eventos, que resultaram na elaboração de documentos como a Declaração de Alma Ata e a Carta de Ottawa, os quais propõem novas concepções acerca do processo saúde/doença, bem como diretrizes para o setor da saúde, articulando saúde às condições de vida (Heidemann, 2006; Randemark, 2009; World Health Organization, 1978, 1986).

No Brasil, as décadas de 70 e 80 ficaram marcadas por importantes transformações sociais e econômicas que determinaram os rumos das políticas públicas de saúde. O acelerado crescimento populacional, as migrações internas que acarretaram a expansão desordenada dos grandes centros urbanos, a queda do crescimento econômico, o endividamento externo, a expansão da dívida pública e a elevação dos juros foram fatores que, somados, culminaram num quadro de recessão e inflação no país (Dimenstein, 1998).

Nesse contexto, a assistência oferecida à população usuária dos serviços de saúde foi deteriorando-se, apesar dos avanços tecnológicos alcançados na época (Dimenstein, 1998). Destaca-se que o modelo de assistência centrado no hospital era predominante e as ações em saúde eram desempenhadas principalmente pelos hospitais privados, os quais tinham o Estado como seu grande financiador. O fracasso deste modelo prestador de serviços, a privatização da assistência médica, a crise financeira da previdência social, os altos índices de desemprego, um perfil epidemiológico marcado por altas taxas de mortalidade materna e infantil, o aumento das doenças infecto-contagiosas e os altos índices de acidentes de trabalho, geraram uma grande mobilização social que ficou conhecida como Movimento Sanitário. Tal movimento trouxe propostas de novas modalidades de atenção à saúde a partir de novas concepções do pensar e fazer saúde, mais humana e universal, que só poderia ser alcançada através de uma ampla reforma sanitária (Camargo-Borges \& Cardoso, 2005).

Em meio ao processo de crise do modelo assistencial, em 1986 foi realizada a $8^{\circ}$ Conferência Nacional de Saúde, na qual se definiram as bases da Reforma Sanitária brasileira (Rosa \& Labate, 2005). Nesta conferência foram discutidos os temas: Saúde como Direito, Reformulação do Sistema Nacional de Saúde e Financiamento do Setor Saúde, os quais 
tinham como finalidade reorganizar o Sistema de Saúde nacional (Ministério da Saúde, 1986; Paim, 2007).

Em 1988, foi promulgada uma nova Constituição Brasileira, que incorporou as propostas da $8^{\circ}$ Conferência Nacional de Saúde, bem como as tendências mundiais quanto às transformações que vinham ocorrendo no setor da saúde. A nova constituição, na página 33, afirma que a "Saúde é direito de todos e dever do Estado", o que garante a todo brasileiro o acesso às ações de prevenção, promoção e recuperação da saúde. Nesse processo, foi proposto o Sistema Único de Saúde (SUS) que consiste no arranjo organizacional do Estado que dá suporte à concretização das políticas de saúde no Brasil. O SUS tem por base os princípios doutrinários da universalidade, equidade e integralidade e as diretrizes organizativas de descentralização, regionalização, hierarquização, integração das ações e a participação comunitária (Constituição da República Federativa do Brasil, 1988; Rosa \& Labate, 2005; Vasconcelos \& Pasche, 2006).

A busca por novas formas de assistência é consequência de um momento históricosocial, em que o modelo centralizado no hospital, na figura do médico e focado na produção da cura, não atende mais à emergência das mudanças do mundo moderno e, consequentemente, às necessidades de saúde das pessoas (Rosa \& Labate, 2005). Essa nova ótica pressupõe a desconstrução da lógica de tratar apenas a doença, para olhar a pessoa, em seu sofrimento e suas necessidades, no contexto da comunidade. De acordo com CamargoBorges (2002), a reorganização do Sistema de Saúde concretizada através do SUS, fundamentada nos princípios e diretrizes acima expostos, propõe que a saúde é conquistada através da possibilidade de vivenciar o processo saúde/doença de maneiras diferentes, através de ações mais amplas e integrais, o que implica, por exemplo, em mais investimentos voltados às comunidades, ao território e em intervenções intersetoriais na saúde, de forma que a assistência em saúde se dê com ênfase na Atenção Primária à Saúde.

Nesse sentido, as equipes de saúde da Atenção Primária, devido a sua proximidade com as famílias e as comunidades, se apresentam como um recurso estratégico para o enfrentamento de importantes problemas de saúde, tanto individual quanto coletiva. De acordo com o Manual para Organização da Atenção Básica (Ministério da Saúde, 1998), a Atenção Primária consiste no conjunto de ações, de caráter individual ou coletivo, situadas no primeiro nível de atenção dos sistemas de saúde, voltadas para promoção da saúde, a prevenção de agravos e o tratamento em geral. Muitas pessoas são assistidas por estas equipes nos grandes e pequenos municípios, o que implica numa forma de responsabilização destes serviços com relação à produção da saúde, buscando eficácia das práticas e promoção da 
equidade, da integralidade e da cidadania (Ministério da Saúde, 2005a). Dentro desse contexto, a Estratégia Saúde da Família (ESF) se configura como a principal modalidade de atuação da Atenção Primária (Delfini, Sato, Antoneli \& Guimarães, 2009; Rosa \& Labate, 2005; Schimith \& Lima, 2004; Tanaka \& Ribeiro, 2009).

\subsection{Estratégia Saúde da Família (ESF)}

O Programa de Saúde da Família (PSF) foi implantado pelo Ministério da Saúde em 1994, resultado de experiências regionais do trabalho de agentes comunitários de saúde no combate à desnutrição infantil e mortalidade materna na região nordeste. O PSF tornou-se uma política nacional do Ministério da Saúde, sendo uma estratégia de reorientação do modelo assistencial da Atenção Primária, caracterizado pelo modelo de atenção biopsicossocial (Ministério da Saúde, s.d.). Recentemente denominada de Estratégia Saúde da Família (ESF), esta iniciativa visa colocar em prática os princípios e diretrizes do SUS, sendo um dos dispositivos substitutivos de organização do cuidado em saúde; objetivando a reorganização da prática assistencial centrada no hospital, com base na Atenção Primária, a partir de estratégias que apontam para o estabelecimento de novas relações entre os profissionais de saúde envolvidos, os usuários, suas famílias e suas comunidades. Busca-se a criação de laços de compromisso e de corresponsabilidade entre o profissional de saúde e a população, além de ter como foco a promoção da qualidade de vida (Ministério da Saúde, 2000; Rosa \& Labate, 2005; Schimith \& Lima, 2004).

As equipes de saúde da ESF são compostas por, no mínimo, um médico generalista (ou da família), um enfermeiro, dois auxiliares de enfermagem e quatro a seis agentes comunitários de saúde (ACS). Posteriormente o cirurgião-dentista, o auxiliar de consultório odontológico e o técnico em higiene bucal foram integrados à equipe da ESF. Cada equipe se responsabiliza pelo acompanhamento de cerca de 3000 a 4500 pessoas ou de mil famílias de uma determinada área, e estas passam a ter corresponsabilidade no cuidado à saúde. A ESF pretende trabalhar ainda, de acordo com o princípio da vigilância em saúde, com atuação interdisciplinar, responsabilizando-se pela integralidade das ações na área de abrangência (Ministério da Saúde, 2000; Schimith \& Lima, 2004).

Nesse sentido, por atuar de acordo com a lógica da desinstitucionalização com maior ênfase no vínculo, a ESF tem se mostrado uma alternativa propícia para o trabalho em saúde 
mental na Atenção Primária, dado que suas equipes estão engajadas no dia-a-dia da comunidade e se propõem a incorporar ações de promoção e educação para a saúde na perspectiva da melhoria das condições de vida da população (Camuri \& Dimenstein, 2010; Quinderé, Jorge, Nogueira, Costa, \& Vasconcelos, 2013; Souza, Matias, Gomes, \& Parente, 2007). Assim, considerando que as políticas de saúde pública e as de saúde mental compartilham princípios comuns, a ESF configura importante ferramenta para a (re) inserção da pessoa em sofrimento mental na sociedade, articulando os pressupostos da Reforma Psiquiátrica de tal forma a se constituir parte de uma rede de cuidados de serviços substitutivos (A. Souza et al., 2007; Arce, Sousa \& Lima, 2011; Delfini et al., 2009; Munari et al., 2008; Souza, Almeida, Veloso, Barbosa \& Vedana, 2013).

\subsection{Reabilitação Psicossocial em saúde mental: aspectos histórico-sociais e o cenário brasileiro atual}

Durante o século XIX, num período de confirmação do capitalismo enquanto um sistema que privilegia o capital e as relações de mercado, a exclusão da loucura foi se configurando como uma lógica pertinente, uma vez que este novo sistema marginalizava aquele que não produzia. Neste sentido, a condição de exclusão da pessoa tida como louca se mistura com as próprias contradições do processo econômico do capitalismo, o que acaba por legitimar as instituições, como as psiquiátricas, que rotulam como doença os comportamentos desviantes de um determinado padrão estabelecido (Alves, 2011; Leão, 2006).

As pessoas em sofrimento mental, tidas como perigosas e improdutivas, foram estigmatizadas por longos séculos. Estiveram fadadas a permanecer à margem da sociedade, isoladas em manicômios, excluídas socialmente, num processo de cronificação de suas condições. De acordo com Rotelli (2000), o manicômio é um grande lugar de improdutividade, o "lugar-zero" de trocas sociais, que destrói qualquer forma de produção de subjetividade. Para A. Souza et al. (2007) e Nicácio (1989), a estrutura física, a organização do tempo e do espaço e a forma como é exercido o controle nesses ambientes, colocam a pessoa institucionalizada numa condição de objeto - sem voz, sem direitos, juridicamente inábil, incapaz e perigoso. Para Amarante (1995), o manicômio se transformou no maior e mais violento espaço de exclusão, de sonegação e de mortificação das subjetividades, 
revelando-se um lugar de exclusão social: lugar do louco, da miséria, dos improdutivos, daquilo que se desencaixa da ordem da razão e da produção.

Diante deste cenário, começaram a surgir os movimentos sociais que lutam por modificações nas condições de tratamento das pessoas em sofrimento mental. Estes movimentos emergiram a partir das propostas de desinstitucionalização da assistência médico-psiquiátrica e das críticas ao modelo asilar e à instituição psiquiátrica, atuando por meio de denúncias da violência nos manicômios, da mercantilização da loucura e da hegemonia de uma rede privada de assistência (Dimenstein, 1998; Ministério da Saúde, 2005a). No Brasil, tendo como referência outros movimentos reformistas ocorridos nos Estados Unidos e na Europa, ganhou destaque o Movimento dos Trabalhadores em Saúde Mental (MTSM), formado por trabalhadores integrantes do movimento sanitário, associações de familiares, sindicalistas, membros de associações de profissionais e pessoas com longo histórico de internações psiquiátricas. Esta mobilização ficou conhecida como Reforma Psiquiátrica, entendida como uma importante reivindicação social por um tratamento digno às pessoas em sofrimento mental (Silva \& Vieira, 2008).

Dado este cenário, o conceito de desinstitucionalização ganha lugar de destaque. Para Nicácio (1989) e Rotelli (2000) trata-se de um processo que visa desconstruir a lógica reducionista que propõe a reclusão dos comportamentos desviantes em instituições. É um processo mais amplo e mais complexo do que apenas a alta hospitalar, a redução do tempo de internação e a diminuição da quantidade de leitos em hospitais psiquiátricos. Trata-se de um processo gradativo de restituir a independência à pessoa em sofrimento mental com relação à instituição psiquiátrica, seja ela hospitalar ou não (Saraceno, 1999, citado por Alves, 2011). Para Amarante (1995), desinstitucionalização significa tratar a pessoa em sua existência e em relação com suas condições concretas de vida; o que implica em não administrar-lhe apenas fármacos ou psicoterapias, mas construir novas possibilidades de vida. Neste contexto, levando em consideração a conjetura sócio-excludente colocada pelo capitalismo, torna-se inviável pensar um ideal de inclusão social em que todos possam estar integrados no mercado formal. Entretanto, podem ser pensadas práticas de inclusão que contemplem os diferentes, enquanto membros de uma mesma sociedade. E é neste contexto que ganha destaque a Reabilitação Psicossocial enquanto uma abordagem que visa possibilitar que a pessoa viva em comunidade, realizando trocas afetivas e materiais, reafirmando sua singularidade, num processo contínuo de reinserção das diferenças dentro de uma mesma sociedade (Randemark, 2009). 
Oliveira e Silva (2000) apontam que o processo de Reabilitação Psicossocial assume o significado de resgate da singularidade e respeito à produção de subjetividade do sujeito, uma vez que propõe a integração da diferença, da multidimensionalidade, em novos contextos. De acordo com Pitta (2001), no sentido instrumental, a Reabilitação Psicossocial representa um conjunto de meios, como programas e serviços, que são desenvolvidos para facilitar a vida de pessoas com problemas severos e persistentes. A Organização Mundial de Saúde (2001) define a Reabilitação Psicossocial como um processo que oportuniza que as pessoas em sofrimento mental atinjam o seu nível potencial de funcionamento independente na comunidade. Tal processo envolve tanto o desenvolvimento de competências individuais como a introdução de mudanças ambientais. Seus principais objetivos são a emancipação do usuário, a redução da discriminação e da estigmatização, a valorização das capacidades individuais e sociais e a criação de um sistema de apoio de longa duração.

De acordo com a Declaración de Valladolid, que consiste em um documento elaborado pelos participantes do III Congresso da Federação Espanhola de Associações de Reabilitação Psicossocial e da II Conferência Europeia de Associação Mundial de Reabilitação Psicossocial, a Reabilitação Psicossocial visa apoiar as pessoas em sofrimento mental para que alcancem um nível ótimo de funcionamento, no qual sejam capazes de enfrentar as barreiras a sua volta, podendo encontrar suas próprias maneiras de viver em comunidade, desenvolvendo habilidades por meio de sua autonomia, sua autoconfiança e suporte dos familiares (Federación Española de Asociaciones de Rehabilitación Psicosocial, 2010).

Saraceno (2001) afirma que a Reabilitação Psicossocial não se trata de uma técnica, mas de uma abordagem, uma estratégia muito mais ampla do que passar um indivíduo de um estado de desabilidade para um estado de habilidade. Tal abordagem implica no empenho dos atores envolvidos no processo saúde/doença, ou seja, os usuários, as famílias, os profissionais e, por fim, a comunidade. De acordo com este autor, todos os indivíduos atuam em três cenários: o cenário habitat, aquele em que se habita, o cenário mercado, aquele da rede social, o cenário trabalho, aquele das trocas com valor social. É dentro destes cenários que acontecem as cenas, as histórias e o entrelaçamento de elementos como dinheiro, afetos, poderes, entre outros. Sendo assim, o processo de Reabilitação Psicossocial seria um processo de reconstrução, de busca do exercício pleno da cidadania e de plena contratualidade nos três cenários. 
Conjeturando sobre como diminuir a cronicidade e como aumentar a capacidade da pessoa dentro da comunidade, Saraceno (2001) pontua que as variáveis que determinam os resultados de um processo reabilitador estão distribuídas em dois extremos: um micro e um macro. O micro diz respeito à afetividade, à continuidade do cuidado, ao vínculo estabelecido entre usuário e profissional. Já o macro, diz respeito à maneira como o serviço está organizado, por exemplo, quanto ao tempo de serviço, aos recursos utilizados, se é aberto à comunidade, se satisfaz as pessoas que atende e aos profissionais que nele trabalham. Ou seja, a Reabilitação Psicossocial implica numa mudança de paradigma em saúde mental e não pode ser reduzida a uma técnica a ser implementada independentemente do contexto, desconsiderando a estrutura do serviço e a comunidade em que se insere.

Alverga e Dimenstein (2006) em suas contribuições acerca dos desafios e impasses de cuidar das pessoas em sofrimento mental em liberdade, colocam como sendo uma dificuldade o imaginário social calcado no preconceito/rejeição em relação à loucura. Os autores apontam para a insuficiência das propostas de reinserção social, na busca da afirmação da autonomia da pessoa em sofrimento. A lógica manicomial atravessa o tecido social, constituindo a força motriz que alimenta as instituições, de forma que as equipes inseridas nos serviços de saúde mental podem, sem que se perceba, reproduzir a institucionalização. Alverga e Dimenstein (2006) e Saraceno (2001) fazem uma crítica à Reabilitação Psicossocial enquanto técnica, pois esta seria uma perspectiva reducionista da proposta da Reforma Psiquiátrica de substituição do modelo asilar, o qual sustenta saberes e práticas cronificadores e de subjugação de uns pelos outros.

No Brasil, a partir dos pressupostos da Reabilitação Psicossocial e dos novos paradigmas quanto ao cuidado em saúde mental, a Reforma Psiquiátrica propiciou inúmeras transformações, atuando em favor de mudanças dos modelos de atenção e gestão das práticas de saúde e em defesa da saúde coletiva, da equidade na oferta dos serviços e do protagonismo dos profissionais e usuários dos serviços de saúde nos processos de gestão e produção do cuidado (Ministério da Saúde, 2005a). Assim, a Política Nacional de Saúde Mental vigente no Brasil objetiva a redução progressiva de leitos em hospitais psiquiátricos e a expansão concomitante de serviços substitutivos como Centros de Atenção Psicossocial (CAPS), Serviços Residenciais Terapêuticos, Centros de Convivência, Ambulatórios de Saúde Mental e Unidades Psiquiátricas em Hospitais Gerais, além de ações de saúde mental no âmbito da Atenção Primária à Saúde. Dado este cenário, tem-se que as novas práticas em saúde mental centram-se em recursos comunitários e em atendimento extra-hospitalar, partindo da lógica de 
desinstitucionalização da assistência psiquiátrica e da garantia dos direitos das pessoas diagnosticadas com transtornos psiquiátricos (Jaegger et al., 2004; Ministério da Saúde, 2005a, 2010; Lei №. 10.216, 2001).

Dentre os desafios e iniciativas da Reforma Psiquiátrica brasileira está a inserção de práticas de cuidados em saúde mental no âmbito das ações que competem à Atenção Primária. Segundo Nunes, Jucá e Valentim (2007), a rede de cuidados à saúde mental deve contemplar a Atenção Primária, uma vez que a Reforma Psiquiátrica prevê a desinstitucionalização do paciente psiquiátrico e a consolidação de bases territoriais para o cuidado em saúde mental. O pressuposto é que grande parte dos problemas de saúde mental possa ser resolvidos em nível da Atenção Primária, sem que haja a necessidade de serem encaminhados a níveis especializados de atenção.

Reinaldo (2008) elenca algumas características atribuídas às ações da Atenção Primária quanto ao cuidado da saúde mental, a saber: estar associada às demais ações da rede básica; assegurar o bem-estar da comunidade e do indivíduo; privilegiar as ações preventivas, individuais e coletivas; alocar os programas de saúde mental em diferentes serviços da rede básica, formando uma rede de suporte; realizar ações diretas e indiretas; utilizar novas estratégias de abordagem em saúde; agregar profissionais com diferentes formações; implicar a comunidade e, por fim, considerar as características da comunidade.

Brêda, Rosa, Pereira e Scatena (2005) apontam para o fato de a Estratégia Saúde da Família, entendida como a principal modalidade de atuação da Atenção Primária no Brasil, compartilhar com a Reabilitação Psicossocial, importantes preceitos relativos aos cuidados em saúde mental. Nesse sentido, os autores destacam as potencialidades da ESF para fortalecer o processo de transição do modelo médico hegemônico para o modelo psicossocial, ampliar a participação e o controle social, resgatar a relação entre profissionais e usuários, oportunizar a diminuição do abuso de alta tecnologia na atenção à saúde e enfatizar a importância da escuta, do vínculo e do acolhimento. Tais aspectos consistem peças fundamentais para a construção de um cuidado mais humanizado, pautado no encontro, focado na pessoa de maneira integral e não na doença, concebendo a doença como parte de um processo, e tendo o território como base de atuação.

Amarante e Giovanella (1994) definem o território como uma força viva de relações concretas e imaginárias que as pessoas estabelecem entre si, com os objetos, com a cultura e com as relações que se dinamizam e se transformam. A partir desta definição, os autores destacam a importância de se conhecer o território, compreendendo a dinâmica das pessoas, famílias e culturas que o constituem, de forma que o trabalho no território não é simplesmente 
a elaboração de um plano de saúde mental para a comunidade, mas, mais que isso, deve incorporar os saberes dos usuários, dos familiares e dos profissionais, bem como os saberes que permeiam as relações, de forma que possam ser construídos objetivos comuns, e que os serviços de saúde possam constituir espaços de reprodução de vida, de subjetividades, de convivência e de sociabilidade. 


\section{OBJETIVOS}





\section{OBJETIVOS}

\subsection{Objetivo Geral}

Conhecer e compreender as ações desenvolvidas pela Estratégia Saúde da Família (ESF) no que se refere à Reabilitação Psicossocial em saúde mental, a partir da perspectiva dos diferentes atores envolvidos, a saber: profissionais de saúde da ESF, usuários em sofrimento mental e seus familiares.

\subsection{Objetivos Específicos}

- Investigar como os usuários, familiares e profissionais compreendem o processo de transformação das práticas em saúde mental, dado o contexto da Reforma Psiquiátrica;

- Descrever as estratégias desenvolvidas pelo serviço de saúde que envolvam o favorecimento de trocas interpessoais, o resgate da cidadania e o respeito às diferenças no que tange as pessoas em sofrimento mental;

- Conhecer como os usuários, familiares e profissionais avaliam as estratégias desenvolvidas na Unidade de Saúde da Família para o cuidado em saúde mental;

- Investigar alternativas de inclusão da pessoa em sofrimento mental no cotidiano da família, da comunidade e do serviço de saúde, abordando os espaços de inclusão e de troca que podem ser criados e/ou apropriados dentro e fora do serviço de saúde. 


\section{JUSTIFICATIVA DO ESTUDO}





\section{JUSTIFICATIVA DO ESTUDO}

Os recursos e potencialidades dos serviços de saúde da Atenção Primária no que tange à assistência à saúde mental é uma temática que vem ganhando destaque na literatura nacional e internacional, tendo em vista a importância da Reabilitação Psicossocial no contexto das comunidades e territórios. Ressalta-se que a Política Nacional de Saúde Mental vigente no Brasil, embasada pela Reforma Psiquiátrica, atribui especial ênfase às ações em saúde mental desenvolvidas no âmbito do território. Atualmente, apesar de todos os esforços visando a desinstitucionalização da assistência psiquiátrica, as pessoas em sofrimento mental ainda enfrentam situações de isolamento e exclusão dentro dos serviços de saúde e de suas próprias casas (Alverga \& Dimenstein, 2006; Pegoraro, 2007; Silva, 2011). Ainda ocupando uma posição de incapazes, improdutivas e, por vezes, perigosas, estas pessoas contam com possibilidades restritas de trocas materiais e interpessoais. E, dado o cenário contemporâneo de intenso incentivo ao consumo, rotinas atribuladas de trabalho, relações interpessoais escassas e superficiais, têm-se que a construção de uma perspectiva de comunidade pautada na solidariedade, no apoio mútuo e no respeito às diferenças, constitui-se, ao mesmo tempo, um desafio e uma proposta de atenção à vida e às múltiplas relações estabelecidas, buscando melhores condições de existência e convivência.

Tendo em vista que a Reabilitação Psicossocial busca desenvolver possibilidades da pessoa viver em comunidade, realizando trocas afetivas e materiais, as Unidades de Saúde da Família se destacam como locais privilegiados para o exercício de práticas de preservação e promoção da saúde mental. As equipes da ESF, por estarem alocadas próximo às famílias e comunidades, dentro de um território delimitado, com atuação pautada no princípio da integralidade do cuidado, têm apontado para a possibilidade de consolidação de estratégias de cuidado em saúde mental visando à recuperação da autonomia e da cidadania das pessoas. Assim, conhecer e compreender as crenças, valores e opiniões que atravessam o cuidado em saúde mental configura uma estratégia de aproximação e questionamento das posturas e práticas instituídas no cotidiano de trabalho, cuja pretensão é avançar nos processos de desmistificação do sofrimento mental e de consolidação de práticas de cuidado mais amplas. Vale ressaltar, ainda, que a possibilidade de dar voz aos atores envolvidos neste contexto, ou seja, profissionais, usuários e familiares, permite conhecer o ponto de vista daqueles que estão implicados na prática, ou seja, no cotidiano dos serviços, oportunizando reflexões mais conectadas com a realidade e que se pretendem úteis para a continuidade do processo de transformações das práticas de saúde. 
MÉTODO 



\section{MÉTODO}

\subsection{Aspectos Éticos}

O projeto de pesquisa foi apresentado às Unidades de Saúde da Família nas quais se pretendia realizar a coleta dos dados, visando averiguar o interesse, por parte dos profissionais destes serviços, em contribuir com o estudo. Após o consentimento das equipes das USFs em participarem do estudo, o projeto de pesquisa foi protocolado na Prefeitura Municipal de Ribeirão Preto, juntamente com o ofício da orientadora solicitando a autorização para realização da pesquisa na Secretaria Municipal de Saúde de Ribeirão Preto (SMS/RP). O ofício de manifestação de concordância da instituição coparticipante encontra-se anexo (Anexo A).

Após obtido o ofício, o projeto de pesquisa foi submetido para avaliação ao Comitê de Ética em Pesquisa da instituição proponente do estudo. Adotou-se os procedimentos básicos e éticos de respeito aos voluntários e à instituição, consoante com a resolução n 466/12 sobre “pesquisa envolvendo seres humanos” (Ministério da Saúde, 2012a). De acordo com o CAAE (Certificado de Apresentação para Apreciação Ética) nº5730712.8.0000.5407, o trabalho foi positivamente avaliado.

Os participantes foram antecipadamente esclarecidos sobre os objetivos e procedimentos do referido trabalho, após o que, foram convidados a colaborar voluntariamente. Foi explicada a ausência de danos e riscos decorrentes de sua participação e a possibilidade de desistência a qualquer momento, sem que isto acarretasse qualquer ônus ao participante. Garantiu-se o sigilo quanto à identificação dos participantes. Aqueles que aceitaram participar voluntariamente assinaram duas vias do Termo de Consentimento Livre e Esclarecido (TCLE) (Apêndice A), ficando com uma cópia do mesmo e devolvendo a outra para a pesquisadora.

\subsection{Caracterização da Situação de Estudo}

O município de Ribeirão Preto, situado a noroeste do estado de São Paulo, possui uma população em torno de 604.682 habitantes (Instituto Brasileiro de Geografia e Estatística, 2010). A rede municipal de saúde está estruturada com Unidades Básicas de Saúde (UBS), 
Unidades Básicas e Distritais de Saúde (UBDS), Unidades de Saúde da Família, Ambulatórios de Especialidades, Núcleos de atenção e diversos Centros de Referências, além da rede hospitalar, de maneira que o município contempla os três níveis de atenção em saúde (Prefeitura Municipal de Ribeirão Preto, 2013).

O município é dividido em cinco Distritos de Saúde, os quais configuram grandes regiões com áreas definidas a partir de critérios econômicos, sociais e geográficos. Cada distrito possui uma UBDS como sede. De acordo com o Plano Municipal de Saúde do município referente ao período de 2014 a 2017, a cidade conta com 48 estabelecimentos de Atenção Primária distribuídos pelos cinco Distritos de Saúde dos quais 5 são UBDS, 14 são Unidades de Saúde da Família (com um total de 30 Equipes de Saúde da Família) e 18 são Unidades Básicas de Saúde tradicionais com 20 Equipes de Agentes Comunitários de Saúde. Destaca-se que a cobertura populacional em maio de 2013 para as Equipes de Saúde da Família foi de 13,9\% e a cobertura para agentes comunitários de saúde (Equipes de Saúde da Família e Equipes de Agentes Comunitários de Saúde) foi de 30,9\% (Prefeitura Municipal de Ribeirão Preto, 2013).

Destaca-se que no município de Ribeirão Preto as “Unidades de Saúde da Família” são referidas tanto por gestores, quanto por usuários e profissionais como "Núcleos de Saúde da Família”. Assim, nos relatos selecionados para ilustrar o tópico de “Resultados e Discussão”, tais serviços de saúde serão referidos pelos entrevistados como "Núcleos”.

\subsection{Escolha das Unidades de Saúde da Família}

A coleta dos dados foi realizada em duas das USFs do município. Para a escolha das USFs, foram considerados os seguintes critérios:

- disponibilidade e colaboração da equipe em aceitar a pesquisa;

- tempo de atuação de acordo com a proposta da Estratégia Saúde da Família;

- ter vínculo com a Universidade de São Paulo (USP);

- realizar o acompanhamento de usuários com queixa de sofrimento mental.

As USFs foram contatadas antecipadamente pela pesquisadora que visava apresentar o objetivo do trabalho e investigar o interesse das mesmas em colaborarem com o estudo. Por atenderem os critérios de inclusão e por demonstrarem interesse em participar do estudo, foram selecionadas duas USFs, as quais, neste trabalho, serão identificadas pelas letras “A” e “B”. 


\subsection{Contato com as Unidades de Saúde da Família}

O primeiro contato com as USFs se deu através de ligação telefônica realizada pela pesquisadora visando agendar uma reunião com as gerentes dos serviços para uma breve apresentação do projeto de pesquisa. Destaca-se que cada USF acolheu, à sua maneira, a pesquisadora e a possibilidade de colaborar com o estudo.

Em reunião com a gerente da USF A, ficou acertado que o projeto de pesquisa deveria ser apresentado à equipe de saúde do serviço antes que o mesmo fosse protocolado na Prefeitura. Assim sendo, na mesma semana, a pesquisadora compareceu à reunião de equipe da Unidade A para apresentação do trabalho, explicitando o objetivo do estudo e esclarecendo como se daria a colaboração dos profissionais no processo de coleta dos dados. Nesta ocasião, a equipe, em conjunto, conferiu um parecer favorável para a realização do estudo. Ficou acertado que após a aprovação do projeto pelo Comitê de Ética, a pesquisadora retornaria à USF A para dar início à coleta dos dados.

Já em reunião com a gerente da USF $B$, foi explicitado para a pesquisadora que o serviço possuia bastante interesse em receber a pesquisa, no entanto, a apresentação do projeto à equipe poderia ser realizada após a aprovação do Comitê de Ética. Nesta ocasião, ficou acordado que após a referida aprovação, a pesquisadora agendaria uma participação na reunião de equipe do serviço para apresentação do estudo aos demais profissionais.

Após aprovação do projeto pelo Comitê de Ética em Pesquisa, em fevereiro de 2013, a pesquisadora voltou a contatar a gerência de ambas as USFs visando apresentar o ofício de aprovação do projeto e solicitar autorização para dar andamento à pesquisa. A gerência da Unidade A se mostrou ciente e autorizou o início das entrevistas. A gerência da Unidade B agendou a participação da pesquisadora na reunião de equipe para apresentação do projeto. Na ocasião da reunião, a equipe da Unidade B se mostrou receptiva ao trabalho e autorizou o início das entrevistas.

\subsection{Constituição do corpus}

A pesquisa foi realizada com profissionais que integram as duas USFs selecionadas; usuários identificados pelas equipes das USFs como estando em sofrimento mental, e, familiares destes usuários, indicados pelos mesmos. 
Para estarem aptos a participar da pesquisa, os participantes deveriam preencher os seguintes critérios de inclusão:

\begin{tabular}{|c|ll|}
\hline Participantes & \multicolumn{1}{c|}{ Critérios de inclusão } \\
\hline Profissionais & $\bullet \quad$ Atuar na USF há pelo menos seis meses. \\
\hline & $\bullet \quad$ Ser usuário cadastrado na USF; \\
& $\bullet \quad$ Possuir 18 anos completos ou mais; \\
Usuários & $\bullet \quad$ Ter registrado em seu prontuário o diagnóstico de algum transtorno mental; \\
& $\bullet \quad$ Ter segmento contínuo na USF. \\
\hline \multirow{2}{*}{ Familiares } & $\bullet \quad$ Possuir 18 anos completos ou mais; \\
& $\bullet \quad$ Ser indicado pelo usuário; \\
\hline
\end{tabular}

Figura 1. Critérios de inclusão dos participantes

A participação daqueles que se voluntariaram a colaborar com o estudo se deu através de uma entrevista aberta, realizada na USF de saúde no caso dos profissionais, e nos domicílios ou na USF no caso dos demais participantes.

\subsubsection{Participantes}

\subsubsection{Profissionais}

Todos os profissionais que compunham as equipes das Unidades A e B foram convidados a participar da pesquisa. Os profissionais foram abordados individualmente pela pesquisadora, que visava apresentar brevemente a proposta do estudo e agendar a entrevista para o momento mais oportuno.

Foram entrevistados todos os profissionais da equipe mínima de ambos os serviços, totalizando dois médicos, duas enfermeiras, onze agentes comunitários de saúde e quatro auxiliares de enfermagem. Também foram entrevistados os dois coordenadores das USFs, 
sendo um de cada serviço; o psiquiatra que fazia a supervisão dos casos de saúde mental em ambos os serviços, dando suporte às equipes; dois dentistas, sendo um de cada equipe e duas psicólogas da Residência Multiprofissional de uma instituição hospitalar de Ribeirão Preto, cada qual referente a um serviço.

Destaca-se que o plano inicial deste estudo previa que fosse entrevistado "pelo menos" um profissional de cada categoria de cada USF, ou seja, um agente comunitário de saúde, um auxiliar de enfermagem, o médico, o enfermeiro, o dentista e o coordenador de cada serviço. Entretanto, dado o interesse e a disponibilidade dos profissionais em participarem do estudo, foi possível realizar a entrevista com todos os membros da equipe mínima de ambas as USFs, além do psiquiatra supervisor e das residentes de Psicologia, totalizado 26 profissionais entrevistados.

A figura a sguir apresenta os profissionais entrevistados quanto a profissão, idade e tempo de atuação na Estratégia Saúde da Família. A fim de preservar a identidade dos mesmos, os nomes reais foram substituídos por nomes fictícios. E, ainda, com a mesma finalidade, optou-se por apresentá-los num único bloco, sem realizar uma diferenciação por equipe de saúde. 


\begin{tabular}{|c|c|c|c|}
\hline \multicolumn{4}{|c|}{ PROFISSIONAIS QUE INTEGRAM AS EQUIPES DAS USFs A e B } \\
\hline NOME & PROFISSÃO & IDADE & TEMPO DE ATUAÇÃO* \\
\hline Miguel & Médico/Coordenador & 48 & 2 anos e meio \\
\hline Jorge & Médico/Coordenador & 55 & 12 anos \\
\hline Maurício & Médico de Família & 37 & 2 anos e meio \\
\hline Raquel & Médica de Família & 35 & 5 anos \\
\hline Fernanda & Enfermeira & 27 & 2 anos \\
\hline Gabriela & Enfermeira & 36 & 2 anos \\
\hline Geraldo & ACS & 52 & 9 meses \\
\hline Antônio & ACS & 59 & 9 meses \\
\hline Tânia & ACS & 39 & 12 anos \\
\hline Marisa & ACS & 42 & 11 anos \\
\hline Fátima & ACS & 53 & 9 meses \\
\hline Catarina & ACS & 48 & 11 anos \\
\hline Carlos & ACS & 54 & 7 anos \\
\hline Tereza & ACS & 48 & 10 anos \\
\hline Lúcia & ACS & 46 & 9 anos \\
\hline Silvana & ACS & 60 & 12 anos \\
\hline Neide & ACS & 62 & 10 anos \\
\hline Andreia & Auxiliar de Enfermagem & 32 & 2 anos \\
\hline Helena & Auxiliar de Enfermagem & 58 & 2 anos \\
\hline Cínthia & Auxiliar de Enfermagem & 45 & 12 anos \\
\hline Marina & Auxiliar de Enfermagem & 34 & 2 anos \\
\hline Ângela & Dentista & 53 & 12 anos \\
\hline Marcos & Dentista & 51 & 12 anos \\
\hline Ana Paula & Residente de Psicologia & 25 & 10 meses \\
\hline Carolina & Residente de Psicologia & 28 & 1 ano e meio \\
\hline Mário** & Psiquiatra & 47 & 12 anos \\
\hline
\end{tabular}

* Informado pelo entrevistado no momento da entrevista.

**Mário é psiquiatra e supervisiona os casos de cuidado à saúde mental das duas USFs.

Figura 2. Descrição dos profissionais entrevistados das Unidades A e B, de acordo com idade, profissão e tempo de atuação 


\subsubsection{Usuários e Familiares}

O plano inicial deste trabalho previa que os usuários a serem entrevistados fossem indicados pelos profissionais da equipe ao final de cada entrevista. Neste caso, pretendia-se identificar aqueles usuários referidos por mais membros da equipe. Para verificar a pertinência do convite para participar do estudo, seriam feitas consultas aos prontuários, tendo em vista os critérios de inclusão já apresentados anteriormente. Entretanto, conforme as entrevistas com os profissionais foram sendo realizadas, percebeu-se certa dificuldade em operacionalizar esse plano. Alguns profissionais não conseguiram indicar nenhum usuário, outros disseram que fariam um levantamento em suas anotações, outros, ainda, acreditavam que não eram os mais indicados para essa tarefa.

Durante o período que esteve nas USFs desenvolvendo as entrevistas com os profissionais, a pesquisadora teve a oportunidade de participar da Consultoria Psiquiátrica, atividade coordenada pelo psiquiatra que dá suporte às USFs quanto às ações de cuidado em saúde mental. Esta atividade acontece semanalmente nas USFs em que o estudo foi realizado e tem participação dos médicos, enfermeiros e residentes de diversas especialidades. A Consultoria é composta por dois momentos consecutivos. Na primeira parte, os profissionais da equipe apresentam para o psiquiatra os casos que suscitaram dúvidas e questionamentos durante a semana. Neste momento, o psiquiatra orienta a equipe, apontando os possíveis entendimentos e encaminhamentos para a situação. Esta etapa da tarefa tem caráter formador, uma vez que objetiva empoderar os profissionais da equipe com ferramentas e recursos para que conduzam os casos de sofrimento mental independentemente dos serviços especializados, evitando encaminhamentos. Na segunda parte, é realizado o atendimento conjunto, ou seja, psiquiatra e equipe atendem conjuntamente os pacientes agendados para receber essa assistência especializada em saúde mental. Para esse atendimento são encaminhados os casos mais complexos, que suscitam dúvidas na equipe quanto ao manejo. Todos os profissionais presentes na etapa anterior acompanham o atendimento, contribuindo com os conhecimentos específicos de sua área de formação.

Diante da possibilidade da pesquisadora participar deste espaço, considerou-se que o momento desta atividade, tanto a sala de espera, quanto a consulta em si, consistia uma oportunidade interessante de acesso aos usuários do serviço que demandam cuidados em saúde mental. Os usuários foram identificados, então, através de três vias: diretamente pela pesquisadora após a mesma presenciar a Consultoria Psiquiátrica; na sala de espera da 
Consultoria, por intermédio de profissionais da equipe; por referência da residente de Psicologia que indicou os usuários que haviam passado em Consultoria recentemente.

A pesquisadora esteve presente em quatro Consultorias, sendo três na USF B e uma na USF A, objetivando conhecer e compreender esta modalidade de intervenção em saúde mental e identificar os usuários que preenchiam os critérios de inclusão no estudo. Foram feitas outras duas tentativas de participar da Consultoria na USF A, entretanto, a atividade fora desmarcada devido a dificuldades da equipe. Uma vez identificados, a pesquisadora entrou em contatou os usuários de duas maneiras: pessoalmente, na sala de espera da Consultoria; através de contato telefônico, visando apresentar brevemente a proposta da pesquisa e agendar a visita domiciliar para realização da entrevista.

Os familiares foram contatados através de indicação dos usuários. Por meio das entrevistas aos familiares, almejava-se realizar uma aproximação da história do usuário a partir de perspectivas diferentes, abarcando aspectos da interação familiar e social, fornecendo mais elementos para a problematização do cuidado em saúde mental ofertado pelas USFs.

Foram entrevistadas três usuárias e duas familiares, todas cadastradas na USF, conforme pode ser visualizado na figura abaixo. Na sequência, as participantes serão apresentadas mais detalhadamente, incluindo os relatos de como se deu a aproximação da pesquisadora.

\begin{tabular}{|c|c|c|}
\hline NOME & IDADE & IDENTIFICAÇÃO/GRAU DE PARENTESCO \\
\hline Amanda & 24 & Usuária \\
\hline Matilde & 59 & Familiar/ Sogra de Amanda \\
\hline Beth & 49 & Usuária \\
\hline Regina & 43 & Usuária \\
\hline Solange & 67 & Familiar / Mãe de Regina \\
\hline
\end{tabular}

Figura 3. Descrição dos usuários e familiares entrevistados das Unidades A e B, de acordo com idade, e grau de parentesco

Vale ressaltar que objetivou-se entrevistar um usuário e um familiar de cada USF, adotando-se a mesma lógica de entrevistar um profissional de cada área, de cada USF. Entretanto, dado a impossibilidade de realizar a entrevista com o familiar de Beth, foi 
necessário que a pesquisadora entrasse em contato com outra dupla usuário-familiar, o que justifica as cinco entrevistas realizadas nesta categoria de participantes.

- Amanda é usuária da USF, tem 24 anos, é casada e mãe de um menino de aproximadamente 6 anos, fruto de um relacionamento anterior. A primeira tentativa de contatar Amanda foi através de ligação telefônica. Quem atendeu foi sua sogra, Matilde, que informou que Amanda não estava em casa, pois tinha ido levar o filho na escola e, depois, iria ajudar o marido na oficina. Sugeriu que a ligação fosse retornada no dia seguinte. Ao retornar a ligação, conforme o combinado, Amanda pôde ser contatada pela pesquisadora que apresentou o objetivo do estudo e agendou a entrevista para o mesmo dia à tarde, em seu domicílio.

A entrevista foi realizada na sala de televisão, que é o primeiro cômodo da casa. Para isso, Amanda pediu que o filho recolhesse os brinquedos e entrasse em casa. Fechou a porta e desligou a televisão. Durante a entrevista, foi solícita e agradável, embora parecesse bastante reservada.

Amanda trabalhava como recepcionista de uma clínica odontológica, mas, no momento da entrevista estava afastada do emprego por motivo de saúde. Refere morar com o marido e o filho na casa da sogra. Relata que procurou o serviço de saúde devido a sentimentos de raiva e tristeza inexplicáveis.

Para participação no estudo, foi indicada pela residente de Psicologia da USF, que estava presente quando Amanda passou pela Consultoria Psiquiátrica. Ao final da entrevista, foi solicitado a Amanda que indicasse alguém de sua família, que participasse de sua trajetória de vida, que pudesse ser entrevistado para tratar dos mesmos assuntos. Ela, então, indicou a sogra “porque ela já teve depressão também” [sic].

No prontuário de Amanda consta as seguintes hipóteses diagnósticas: Episódio Depressivo Maior Grave, Transtorno de Personalidade Emocionalmente Instável, Transtorno de Ansiedade Generalizada e Transtorno do Pânico.

- $\quad$ Matilde, 59 anos, sogra de Amanda. Relatou que trabalha como cuidadora de uma senhora idosa em uma casa de família, entretanto, acrescentou que em breve deixará esta atividade para se dedicar às tarefas domésticas. Também desenvolve junto a um dos filhos um trabalho de entrega de medicamentos. 
Durante a entrevista, focou seu relato em sua própria experiência de sofrimento mental, referindo que enfrentou um período de entristecimento quando ficou sem trabalhar. Quando interrogada especificamente sobre a saúde de Amanda, Matilde foi enfática ao afirmar que não tinha o que dizer sobre a saúde da nora, pois não houve diálogo entre as duas sobre esse assunto. Nos dias posteriores a entrevista, a pesquisadora voltou a procurar Amanda com o intuito de solicitar que ela indicasse alguém de sua convivência, que acompanhasse seu dia-a-dia e que pudesse conversar mais especificamente sobre sua saúde. Tentou-se contato telefônico e uma visita ao domicílio. Em todas as tentativas, a pesquisadora foi atendida por Matilde, a qual, embora muito solícita, parecia bastante resistente em fornecer informações sobre a nora. Restringiu-se a passar o número do celular de Amanda e informou que a mesma estava na casa da mãe. Foram feitas inúmeras tentativas de contatar Amanda pelo celular, em diferentes dias e horários. Sem conseguir acessá-la, a pesquisadora conversou com alguns profissionais da USF sobre a família em questão. Eles revelaram que há uma desconfiança da equipe de que Amanda não seja, de fato, moradora da área, mas, afirme morar com a sogra visando ter acesso ao cuidado ofertado pela USF. Essa hipótese parece justificar o receio de Matilde em fornecer informações sobre Amanda.

- $\quad$ Beth é usuária da USF, tem 49 anos, é casada e mãe de três filhos do primeiro casamento. Foi contatada por meio da Consultoria Psiquiátrica, na qual a pesquisadora estava presente. Procurou ajuda do serviço de saúde com queixas de tristeza, ansiedade e sobrecarga de tarefas. Tem um filho acamado, Vítor, de 25 anos, que teve anóxia no nascimento. Atualmente, mora com o marido, os três filhos e um neto. Seus pais moram na casa imediatamente ao lado. A filha teve um primeiro casamento conturbado. Tem um filho de aproximadamente sete anos que é cuidado por Beth. Segundo ela, a filha também “não é certa da cabeça” [sic]. Recentemente, a filha ficou tão nervosa que quebrou a mesa de vidro da sala de jantar da família com um soco.

Beth está afastada do emprego e tem se dedicado integralmente a casa e à família. É ela quem faz fisioterapia em Vítor, troca sonda, administra a medicação e tudo o mais que é necessário. Refere ter muito medo de morrer e deixar o filho. Também tem muito medo que o filho morra. Relatou que o caso de Vítor é tido como exemplo na APAE, pois é o menino nesta situação com maior tempo de vida. Com exceção de 
Vítor, o caso com mais tempo de vida morreu aos 18 anos. Beth entende isso como um prenúncio da morte do filho.

Após a Consultoria, foi feito contato telefônico com Beth para convidá-la a participar do estudo. Diante da resposta afirmativa, foi agendada a entrevista para dois dias depois, em seu domicílio. No dia da entrevista, Beth encontrava-se na calçada, de saída, quando a pesquisadora chegou. Contou que estava indo ao supermercado, mas que poderia fazer isso em outro momento. Ao atravessar a garagem da casa, o primeiro cômodo é uma sala de televisão, onde Vítor estava deitando em frente a um televisor ligado. A entrevista foi realizada neste cômodo, em companhia de Vítor.

Após a entrevista, foi solicitado à Beth que indicasse alguém de sua família para ser entrevistado, ao que a usuária atendeu indicando a filha e fazendo o apontamento de que “Letícia também não é muito certa, não. Você vai ver” [sic]. Informou o horário que a moça estaria em casa e disse que a pesquisadora poderia comparecer no dia seguinte.

Conforme acordado, a pesquisadora retornou à casa de Beth no dia seguinte para entrevistar Letícia, entretanto, a moça não foi encontrada. Posteriormente, foram feitas novas tentativas de contato telefônico e visita domiciliar, entretanto, sem êxito.

No prontuário de Beth consta o diagnóstico de Transtorno Depressivo Maior com sintomas de ansiedade e agitação.

- $\quad$ Regina é usuária da USF, tem 43 anos, é casada, professora de música, não tem filhos. O primeiro contato com Regina foi realizado na sala de espera da Consultoria. $\mathrm{Na}$ ocasião, Carolina, residente de Psicologia, informou que tanto Regina quanto sua mãe seriam consultadas pelo psiquiatra naquele dia. Na opinião da residente, tratava-se de pessoas interessantes para serem entrevistadas. Afirmou que Regina é uma pessoa solícita, disposta e que gosta de falar.

Carolina apresentou a pesquisadora à Regina e Solange e ambas prontamente aceitaram participar do estudo. Foi acordado que as entrevistas seriam realizadas antes da Consultoria, e, caso chegasse a vez de uma delas ser consultada, Carolina ficaria responsável por chamá-las.

Durante sua entrevista, Regina relatou que, inicialmente, trazia a mãe para ser consultada pela Consultoria Psiquiátrica da USF. Posteriormente, passou a ser atendida também devido a queixas de tensão e nervosismo excessivos. 
Regina mora com o marido e a mãe e relata que mantém um relacionamento conturbado com ambos, manifestando, inclusive, desejo de morar sozinha. Faz referência ao marido como "uma pessoa muito difícil, problemática. [...] pessoa muito difícil de lidar” [sic]. Regina integra, através do marido, uma família reconhecida pela USF pelas queixas de depressão, comum a grande parte dos membros, e pela troca de medicamentos que realizam entre si. Muitos membros desta família moram lado a lado, numa mesma rua. Sobre a família do marido, afirma "A família inteira é problemática. Tudo tem depressão” [sic].

Durante a entrevista, chorou bastante, mostrando-se fragilizada. Em virtude dessa situação, solicitou que a entrevista com a mãe fosse agendada para outro dia. Passou seu telefone e pediu que a pesquisadora entrasse em contato. A entrevista com a mãe foi, então, agendada para dois dias depois.

No prontuário de Regina consta o diagnóstico de Transtorno de Ansiedade Generalizada e sintomas de depressão.

- $\quad$ Solange, 67 anos, mãe de Regina. Refere uma vida bastante atribulada. Sofria agressões do pai quando criança. A mãe morreu no parto de um dos irmãos. Casou-se nova para sair da casa do pai. O marido morreu atingido por uma raio, deixando-a grávida de três meses. Voltou para a casa do pai, que ainda a agredia. Assim que pôde, fugiu com um vizinho sitiante, viúvo, cerca de 40 anos mais velho do que ela. Desta união nasceu Regina e o terceiro e último filho. Segundo ela, o casamento não deu certo devido à infidelidade do marido. Já mais velha, por receio de ficar sozinha, casou-se pela terceira vez. Entretanto, esta união durou pouco porque, segundo Solange, o marido contraía dívidas e não as pagava. Atualmente mora na casa de Regina, com quem afirma se preocupar muito. De acordo com a residente de Psicologia, mãe e filha desenvolveram uma relação simbiótica.

Solange é acompanhada pela Psiquiatria da USF há muitos anos e devido a diferentes razões. Já foi alcoolista, já tentou suicídio, já esteve internada no hospital psiquiátrico da cidade. Relata que, às vezes, "a cabeça fica atrapalhada” [sic]. 


\subsection{Instrumentos}

\subsubsection{Entrevistas}

Foram realizadas entrevistas abertas e individuais e baseadas no processo descrito por Rey (2005), denominado conversação, cujo objetivo é conduzir a pessoa entrevistada a campos significativos de sua experiência pessoal, de forma a levá-la a percorrer os diferentes espaços constituintes de sua subjetividade individual. De acordo com o autor, a partir desses espaços, o relato expressa, de forma crescente, o mundo, as necessidades, os conflitos e as reflexões do entrevistado. A conversação busca a expressão compromissada do sujeito que fala. Assim, parte-se do mais geral para o mais íntimo, aproveitando os momentos em que a própria conversação vai entrando nessas experiências.

A conversação enquanto instrumento valoriza o caráter processual da relação com o outro, visando superar o caráter instrumental que caracteriza o uso da entrevista. Dessa forma, almejou-se transcender o uso de questionário oral ou interrogatório, buscando construir um processo de comunicação, resgatando o aspecto interativo. Trata-se de um sistema no qual os participantes se orientam em seu próprio curso e em que os aspectos significativos aparecem na medida em que as pessoas envolvidas avançam em suas relações. Para tanto, foi elaborada uma questão disparadora para cada categoria dos entrevistados da pesquisa, a saber: a) profissionais de saúde - "Você pode me contar sobre a sua atuação com relação aos usuários com queixa de sofrimento mental?”; b) usuários em sofrimento mental - "Você pode me contar sobre as suas experiências com relação à sua saúde mental?”; c) familiares de usuários em sofrimento mental - "Você por me contar sobre sua experiência de convívio com (nome do usuário)?”. Cada participante foi convidado a falar acerca da temática proposta, dispondo do tempo que julgou necessário, tendo a pesquisadora assumido uma postura reflexiva e investigativa acerca da conversa.

Rey (2005) afirma que as intervenções do pesquisador devem assumir um caráter reflexivo em relação ao momento da conversação, sem que negligencie o tema-objeto da pesquisa. Neste sentido, foi elaborado um roteiro com temas orientadores da entrevista para cada categoria de participantes com a finalidade de contemplar os objetivos do presente estudo (Apêndices B, C e D). Os temas propostos no roteiro foram introduzidos pela pesquisadora a medida que transcorria a entrevista, conforme a necessidade. 
Antes de iniciar a entrevista, o TCLE foi lido e assinado pelos participantes. Foram entregues duas cópias do TCLE para cada entrevistado, que deveria assiná-las e devolver uma das vias à pesquisadora. Foram solicitados alguns dados de identificação do participante, tais como idade, ocupação e escolaridade. Esclarecidas as dúvidas e com o consentimento dos participantes, as entrevistas puderam ser iniciadas. As entrevistas foram audiogravadas com o respectivo consentimento dos participantes.

\subsubsection{Observação Participante}

A observação participante, conforme Delgado e Gutiérrez (1995) é a observação sistematizada de grupos reais ou de comunidades em sua vida cotidiana, fundamentalmente realizada através de estratégias empíricas e técnicas de registro qualitativas. Para este estudo, utilizou-se a observação participante, de forma direta, uma vez que a pesquisadora participou de atividades específicas realizadas pelos colaboradores da pesquisa. As informações obtidas através da observação foram utilizadas como complemento aos dados obtidos por meio das entrevistas, realizando, assim, a investigação exploratória da interação dos membros da equipe entre si, bem como da interação entre os usuários e os membros da equipe, em situações de atividades que compunham a rotina das Unidades de Saúde da Família.

As observações foram realizadas durante os períodos em que a pesquisadora permaneceu nas Unidades de Saúde da Família, participando de atividades específicas, como reunião de equipe e Consultoria Psiquiátrica, ou simplesmente integrando o ambiente de trabalho. Ressalta-se que a pesquisadora frequentou as USFs no período de março a dezembro de 2013, permanecendo nas Unidades de um a três períodos por semana. As observações foram seguidas por anotações em diário de campo realizadas posteriormente às atividades. Assim, buscou-se apreender momentos nos quais as interações observadas pudessem trazer contribuições acerca do cotidiano do serviço e da relação estabelecida entre as pessoas integrantes deste contexto, de forma a complementar as informações das entrevistas, contribuindo para a compreensão das ações de cuidado à saúde mental. 


\subsection{Análise do corpus}

A análise dos dados foi realizada utilizando-se a abordagem qualitativa em pesquisa. Segundo Minayo (2012), a matéria prima das pesquisas qualitativas é composta por opiniões, crenças, valores, representações, relações e ações humanas e sociais. Já a análise se baseia em compreender, interpretar e dialetizar. Assim, as metodologias de pesquisa qualitativa são capazes de apreender os significados intrínsecos aos atos, à vivências e às relações. Segundo a autora, "a análise qualitativa de um objeto de investigação concretiza a possibilidade de construção de conhecimento e possui os requisitos e instrumentos para ser considerada e valorizada como um constructo científico” (p. 626).

Primeiramente, as entrevistas audiogravadas foram transcritas na íntegra, quando, então, pôde ser realizada uma primeira aproximação com o material coletado.

Como instrumento para análise dos dados foi utilizado o método de Análise de Conteúdo, o qual, segundo Bardin (1977/2011) consiste num “conjunto de técnicas de análise da comunicação visando obter, por procedimentos sistemáticos e objetivos de descrição do conteúdo das mensagens, indicadores que permitam a inferência de conhecimentos relativos ao modo como tais mensagens foram produzidas, transmitidas e recebidas” (p. 48). A Análise de Conteúdo foi realizada na modalidade “temática”, uma vez que esta possibilita a descoberta dos núcleos de sentido que compõem uma comunicação, cuja presença ou frequência possam significar aspectos do conteúdo estudado. Nesta perspectiva, o “tema” é compreendido como a unidade de significação que se destaca naturalmente de um texto analisado segundo critérios relativos à teoria na qual se baseia a leitura (Bardin, 1977/2011; Minayo, 1992/2004).

O processo de Análise de Conteúdo Temática é composto por três etapas: A primeira delas é a Pré-análise, que consiste na leitura flutuante dos textos, tomando contato exaustivo com o material e com seu conteúdo. Esta é a fase de constituição do corpus, organizando o material na tentativa de responder a normas de validade: exaustividade, representatividade, homogeneidade e pertinência. A segunda etapa é a de Exploração do material, a qual consiste, essencialmente, na codificação do material pesquisado, entendida como o processo de transformação dos dados, feita através de recortes, agregação e enumeração, permitindo atingir uma representação do conteúdo capaz de esclarecer o pesquisador acerca das características do texto. A última etapa é a do Tratamento dos resultados e interpretação, na qual os resultados brutos são categorizados, e realizam-se inferências a partir dos recortes e 
agrupamentos elaborados, isto é, interpretações sobre o conteúdo que se pretende analisar (Bardin, 1977/2011).

A Análise de Conteúdo clássica, por ser um método de análise das comunicações, enfatiza prioritariamente o conteúdo que emerge da coleta dos dados. No caso deste estudo, este instrumento de análise terá seu uso adaptado de forma a considerar, como igualmente importante, o contexto no qual está sendo feita a coleta. Para a análise do material foi realizado a interlocução com a produção acadêmica da área da saúde coletiva e da saúde mental bem como com os documentos oficiais do Ministério da Saúde. Optou-se por realizar este diálogo como recurso para situar o estudo em relação ao que está sendo e ao que já foi produzido nesta mesma temática, localizando suas bases teóricas e suas possibilidades de contribuições. 



\section{RESULTADOS E DISCUSSÃO}

A partir da análise das entrevistas foram construídas seis categorias temáticas, as quais podem ser visualizadas na figura a seguir:

\section{CATEGORIAS}

\section{SUBCATEGORIAS}

5.1. Contextos e relações: Necessidades apontadas como sendo o motivo pela procura por ajuda na USF

5.2.1. Consultas, encaminhamentos, internações $e$ medicamentos: o lugar das estratégias tradicionais na ESF

5.2. Ações: o desafio de cuidar da saúde mental no território

5.2.2. A escuta e a conversa como estratégias de promoção e preservação da saúde mental

5.2.3. Vínculo e Cuidado Longitudinal

5.2.4. O trabalho em equipe como ferramenta para o cuidado à saúde mental

5.2.5. Desenvolvimento de estratégias coletivas e apropriação de espaços comunitários

5.3. O contato com o sofrimento mental e o preparo para o trabalho: caminhos para a transformação das práticas

5.4.1. Falta de suporte psicológico

5.4. Dificuldades encontradas no 5.4.2. Insuficiência de preparo técnico processo de cuidado da saúde mental

5.4.3. Dificuldade de organização dos processos de trabalho 5.4.4. Insuficiência e/ou desarticulação da rede

5.5. Avaliação do cuidado em saúde mental ofertado pelas Unidades de Saúde da Família

5.6. Transformações do cuidado em saúde mental: Concepções dos participantes acerca da pessoa em sofrimento mental e da viabilização da desinstitucionalização e da Reabilitação Psicossocial

Figura 4. Categorias temáticas e subcategorias correspondentes

Destaca-se que o cuidado em saúde mental é o eixo principal que atravessa as categorias temáticas, através das quais se procurou analisar os sentidos e significados, crenças e valores, atribuídos pelos entrevistados aos diferentes aspectos que compõem o ato de cuidar e ser cuidado. Mais especificamente, buscou-se conhecer e compreender como os entrevistados identificam e significam as necessidades de cuidado em saúde mental; as ações 
ofertadas visando atender a estas necessidades; o preparo necessário para este cuidado; as dificuldades encontradas no processo de cuidar; a avaliação dos serviços e ações; as concepções que atravessam as práticas no que tange ao processo de desinstitucionalização da assistência psiquiátrica.

Cabe assinalar que este trabalho compartilha com Ayres (2000) a noção de que o cuidado está associado à “promoção do bem-estar”, indo além da “correção de distúrbios” (p. 118). Segundo o autor, ao reduzir o indivíduo à condição de portador de um problema a ser resolvido, é atribuído a ele o lugar de objeto sobre o qual os profissionais de saúde atuam. Entretanto, sob outra perspectiva, compreendendo este mesmo indivíduo como aspirante ao bem-estar, é-lhe atribuído o lugar de sujeito, detentor do poder de juízo sobre suas necessidades. Ayres (2004) apresenta uma definição de cuidado enquanto um constructo filosófico e uma atitude prática que envolve a interação entre duas ou mais pessoas, visando o alívio de um sofrimento ou o alcance de um bem-estar. E, de acordo com Merhy (2000), é do indivíduo (objeto-sujeito), o qual inexoravelmente participa do momento assistencial, que pode surgir a demanda por arranjos tecnológicos mais sensíveis a necessidades de saúde de indivíduos e coletivos.

Na mesma direção, tem-se o conceito de cuidado conforme formulado por Leonardo Boff (2000 citado por Alves \& Guljor, 2005, p. 227):

“O que se opõe ao descuido e ao descaso é o cuidado. Cuidar é mais do que um ato; é uma atitude. Portanto, abrange mais que um momento de atenção, de zelo e de desvelo. Representa uma atitude de ocupação, preocupação, de responsabilização de envolvimento afetivo com o outro".

Alves e Guljor (2005), a partir dessa perspectiva e levando em conta o contexto da saúde mental, definiram algumas premissas fundadoras do cuidado, das quais serão destacadas as três primeiras. A primeira delas é a da liberdade em negação ao isolamento, a partir da qual se opera uma ruptura com a necessidade de manter a pessoa em sofrimento mental isolada de seu meio, para que seu quadro seja identificado. Ao legitimar a liberdade, legitima-se também o respeito às diferenças e, sob esta ótica, o ato de cuidar implica em investir na capacidade da pessoa para operar suas próprias escolhas, estabelecendo seus próprios conceitos e juízos, pautados na singularidade de sua história. A segunda premissa é a da integralidade em negação à seleção, a partir da qual a pessoa em sofrimento mental é compreendida como tendo necessidades que atravessam diversos campos. Assim, o ato de cuidar implica transcender o olhar sobre a doença, abarcando o conjunto de fatores que envolvem a vida. A terceira premissa diz respeito ao 
enfrentamento do problema e do risco social em contraposição ao modelo nosológico. Sob essa premissa, o diagnóstico, que antes determinava a condução terapêutica, passa a ser incorporado a novos aspectos que envolvem a existência da pessoa em sofrimento mental. Assim, pode-se estabelecer uma visão ampliada da pessoa, considerando a rede em que se insere, e, consequentemente, oportuniza-se a compreensão do processo de crise, atribuindo-lhe um sentido e um lugar numa história em curso.

À vista disso, abaixo serão apresentadas as categorias e subcategorias.

\subsection{Contextos e relações: Necessidades apontadas como sendo o motivo pela procura por ajuda na USF}

Esta categoria aborda as necessidades identificadas pelas usuárias como motivadoras da busca por ajuda nas USFs. Didaticamente, para melhor apresentação e compreensão das situações relatadas, optou-se por apresentá-las por meio de uma subdivisão em tópicos das participantes e suas respectivas familiares.

a) Amanda e Matilde

Durante a entrevista com Amanda foram abordadas as razões pelas quais ela estava seguindo em consulta com o psiquiatra na USF. Buscou-se conhecer o ponto de vista da usuária sobre sua condição e tratamento. A este respeito, relatou:

"Por causa que eu to com depressão. Ah, eu não sei, é depressão e um outro... um outro problema que ele falou que tem que é de humor. Não chega a ser o Transtorno Bipolar. É um transtorno que parece que não tem cura. Que eu vario de humor mais de 10 vezes por dia. Então, aí, ele falou isso. Aí, eu to fazendo tratamento. [...] Faz quase 10 anos. [...] Ai, é uma tristeza que não dá pra explicar. É tristeza, tem hora que eu to bem, tem hora que eu não to. Não dá pra... Não sei explicar. É uma coisa muito ruim. [...] Muito. Muito, muito, muito. Pra mim tudo... Eu não tenho paciência com nada. Eu não sei esperar nada. Ao mesmo tempo que eu espero, passa cinco minutos eu já não quero esperar mais. Eu to nos lugares, eu tenho vontade de ir embora. Eu não fico de jeito nenhum. [...] Tem dia que eu não consigo me controlar. Eu fico muito, mais muito nervosa. É o que eu to te 
falando. Eu vario de humor mais de 10 vezes por dia. Eu não consigo me controlar tem hora. [...] Eu falo 'nossa, eu não acredito'. Tem hora... é... o Dr. Mário perguntou pra mim se o meu casamento tinha alguma coisa. Eu falei pra ele que não. Que o meu marido fazia pra mim o que tava no alcance dele e que eu não tinha nada pra reclamar dele. Que ele é uma pessoa muito boa pra mim e pro meu filho. Aí, ele perguntou se eu sentia alguma coisa. Tem hora que me da vontade de matar ele. Eu não sei porque. Eu sinto uma raiva muito, mas muito, muito grande! [...] E tem dia que eu to muito irritada com o meu filho. [...] E, tem dia que eu to muito irritada. Eu não quero fazer nada. Eu não quero conversar com ninguém. Eu não quero que ninguém conversa comigo. Eu quero que me deixa em paz, no meu canto. É isso. [...] Não melhorou (com o uso da medicação). Ele amenizou. Mas não melhorou. Eu achava que ia melhorar bem mais. Só que não adianta. Não melhora."

(Amanda, Usuária)

Na ocasião da entrevista, Amanda havia passado pela primeira vez pela Consultoria Psiquiátrica, apesar de já estar sendo acompanhada pelo médico de família da USF há algum tempo. Quanto aos reflexos dos sintomas em seu ambiente de trabalho e a consequente conduta da USF, Amanda relatou:

“Eu to afastada. O doutor me afastou. Ele achou melhor eu não trabalhar. [...] Primeiro o Dr. Maurício e depois o Dr. Mário. [...] Eu achei melhor (o afastamento). Porque no meu serviço era a mesma coisa. Eu não tava bem. Eu não queria conversar com ninguém. Se me desse na telha de ir embora, eu ia embora e pronto. [...] Aí, chegou um tempo que eu falei 'Ó, Dr. Maurício, eu não consigo ir mais'. Aí, foi onde ele me afastou até dar o tempo do INSS. Aí, o Dr. Mário agora vai me dar o laudo e vai me dar o atestado por tempo indeterminado, porque ele (o médico) falou assim que não sabe até onde vai. [...] Mas eu acho, assim, que no meu caso, acho que não tem muito o que fazer. Porque o meu é uma doença que não tem cura. Eu vou continuar com isso pro resto da vida. Então, eu tenho desde criança. [...] Eu vou ter que conviver pro resto da vida. E eu não sei como que eu vou fazer. Porque se tivesse cura, ainda até que a gente podia falar 'Olha, o Núcleo pode ajudar, pode oferecer alguma alternativa'. Mas, no caso, não tem alternativa.”

(Amanda, Usuária)

Em seu relato, Amanda descreve sua situação enfatizando os sintomas que a fizeram buscar ajuda no serviço de saúde, ou seja, irritabilidade, impaciência, variação de humor, tristeza e raiva sem motivo aparente. Sentimentos difíceis de nomear e de controlar, os quais, segundo ela, aparecem e desaparecem inesperadamente. Amanda dá indícios de que não tem muitas informações sobre sua condição, apresentando algumas hipóteses diagnósticas confusas e evidenciando a crença de que sua doença não tem cura. Acrescenta, ainda, que o 
tratamento medicamentoso prescrito pelos profissionais da USF não havia apresentado, até aquele momento, o êxito desejado. Dado este cenário, considera-se que conhecer e compreender o diagnóstico consiste em parte importante do processo de cuidado, e, nesse sentido, se Amanda tivesse a oportunidade de dialogar mais sobre sua saúde, na tentativa de entender melhor os sintomas que a acometem, considerando e experimentando alternativas de cuidado à saúde mental complementares às medicamentosas, talvez o enfrentamento da situação relatada por ela pudesse representar um processo menos confuso e misterioso, cuja melhora não estivesse unicamente atrelada ao efeito da medicação.

Amanda evidencia a crença de que "o Núcleo não pode ajudar porque o caso não tem alternativa" [sic], nesse sentido, infere-se que a continuidade de seu tratamento fique comprometida, dado que a usuária acredita que o problema está nela e não há o que um serviço de saúde possa fazer. Esta forma de compreender sua situação pode contribuir para o isolamento e possivelmente para a ampliação do sofrimento, uma vez que a crença de que seu caso é incurável pode comprometer a motivação para buscar ajuda.

Quanto ao emprego, Amanda relata que devido à intensa variação de humor, estava tendo dificuldade em manter-se no ambiente de trabalho, e, diante de tal situação, a conduta da equipe foi "dar o laudo e dar o atestado por tempo indeterminado" [sic]. Infere-se que administrar os medicamentos e propor o afastamento do emprego podem representar uma ajuda significativa na condição de Amanda, entretanto, tal conduta deve estar atrelada a uma série de outras estratégias, no âmbito da atenção psicossocial, visando, por exemplo, ajudá-la a significar seus sintomas, a organizar sua rotina, a administrar o tempo em que ficará em casa em função do afastamento e a procurar outras atividades que lhe façam bem.

A entrevista com Matilde foi breve e não fluiu com facilidade. Bastante reservada, ateve-se a falar sobre a própria experiência de depressão.

"[...] eu cheguei a procurar eles aqui também, assim, meia depressiva. Mas, foi uma coisa, assim, muito rápida. [...] Sobre o que você ta perguntando, isso, assim, em relação a depressão, né, aí, rapidinho eu vi que eu mesma tinha que mudar o ritmo, né, foi onde que eu comecei a... Eu sempre trabalhei, e naquela época eu tinha dado uma parada. Eu vi que não era por aí, não. Aí, eu voltei a trabalhar e eu acho que até demais da conta. Aí, os problemas até... até se foram.[...] Eu falo baseado em mim. Pra mim o serviço foi o medicamento que eu precisava: usar a minha cabeça. [...] Uma orientação (que a USF poderia dar para Amanda) (é) pra (que) ela firme no emprego. Não sei. Às vezes o que é bom pra mim não é bom pra ela, né? Cada um é cada um." 
Matilde destacou a própria experiência de sofrimento, referindo que para ela, “o serviço foi o medicamento que precisava: usar a cabeça” [sic]. Chegou a procurar a USF com sintomas de depressão, mas “rapidinho viu que ela mesma tinha que mudar o ritmo” [sic]. Matilde dá indícios de que se coloca como agente de sua própria saúde, compreendendo o cuidado ofertado pela USF como uma das partes que integram o processo de cuidado em saúde mental. Para ela, a remissão dos sintomas de depressão está fundamentalmente associada à iniciativa própria de desenvolver estratégias complementares ao uso dos antidepressivos, dos quais ela não queria depender. Então, partindo de sua própria experiência, Matilde sugere que a USF poderia ajudar sua nora por meio de orientações para que ela não abandone o emprego e se dedique a esta atividade. Destaca-se que Matilde, conhecendo Amanda, sugere uma orientação contrária à que foi ofertada pela USF. Assim, infere-se que seria importante para o planejamento dos processos de cuidados de Amanda, que fosse levado em conta a perspectiva daqueles que convivem cotidianamente com a usuária, uma vez que, a exemplo de Matilde, observou-se que a sogra se posicionou diante da situação recorrendo não apenas à sua experiência própria, mas, também, àquilo que conhece de Amanda a partir de sua convivência com ela. Pini e Waidman (2012) consideram o compartilhamento das particularidades dos casos com a família como um fator de impacto positivo das ações da ESF sobre a pessoa em sofrimento mental. A família, ao ser identificada como foco de cuidados, pode integrar os espaços de planejamento e ação, facilitando a comunicação e a troca de informações. Nesse sentido, parece válido que seja feita uma maior aproximação com o contexto do usuário para a tomada de uma decisão importante como a do “afastamento por tempo indeterminado", visando abarcar os sentidos, significados e consequências das orientações ofertadas pelo serviço.

\section{b) Beth}

Beth foi contatada pela pesquisadora por meio da Consultoria Psiquiátrica. Na ocasião, estavam presentes a pesquisadora, a médica de família, o profissional especialista em saúde mental, a residente de Psicologia e outras três residentes que não se identificaram. Antes da usuária ser convidada a entrar na sala, a médica de família fez uma breve apresentação do caso para os profissionais presentes. Relatou que Beth (49 anos) tem diagnóstico de Transtorno Depressivo Maior e é pouco aderente ao tratamento. É muito agitada, ansiosa, fala muito, tem dificuldade para dormir e tem dores crônicas. 
A médica de família relatou estar insegura de manter Beth apenas no consultório e sugeriu que a usuária passasse pela Consultoria Psiquiátrica. Segundo a médica, Beth aderiu bem à sugestão.

Ao entrar para a consulta, Beth relatou estar triste e ansiosa, sentindo-se sobrecarregada. O especialista em saúde mental interrogou a usuária a respeito dos medicamentos em uso. Constatou-se que Beth estava fazendo confusão com a dose da medicação: tomando um comprimido (10mg) ao invés de um e meio (15mg). Cogitou-se que a medicação não estivesse fazendo o efeito esperado devido ao fato da usuária estar tomando uma quantidade inferior à prescrita. Assim, foi mantida a prescrição de 15mg.

Beth chorou quando a médica mencionou o nome de Vítor (filho acamado devido à anóxia neonatal) e também ao falar sobre seu marido. "Me pegou da sarjeta e cuidou de mim” [sic]. Revelou que é bom chorar e que volta pra casa aliviada quando vai à USF e chora um pouquinho. Quando está em casa, tenta manter a postura de “durona, mãezona que dá conta de tudo" [sic]. Para ir à Consultoria, Beth deixou Vítor sob os cuidados de sua mãe, mas referiu que não fica tranquila, pois a mãe fica alarmada a qualquer tosse e liga pra Beth com frequência, afirmando medo do menino morrer a qualquer momento. Durante a consulta, ao receber uma ligação de sua mãe, Beth concluiu: “Tá vendo? Eu não posso sair” [sic].

O especialista em saúde mental aconselhou que Beth cuidasse mais de si e reservasse mais tempo para atividades que lhe fizessem bem, no entanto, não foram exploradas quaisquer possibilidades concretas de viabilizar estas indicações. Beth concordou com o profissional e afirmou "eu precisava de uma atividade física”. Na sequência, sem que o comentário da usuária provocasse novas reflexões, foi enfatizado o uso correto da medicação e Beth foi interrogada sobre a possibilidade de começar uma psicoterapia no próprio serviço. A usuária concordou e a residente de Psicologia se comprometeu a entrar em contato para agendar o horário do primeiro encontro. Foi entregue a receita da medicação e Beth foi embora. Em seguida, o especialista em saúde mental comentou com os demais: "Ela vai deprimir quando esse menino morrer. Você vai ver” [sic]. Completou dizendo que pessoas que vivem em função de outra têm muita dificuldade para aceitar a perda.

Já durante a entrevista, quando interrogada sobre as razões pelas quais está passando em consulta com o psiquiatra, respondeu:

"Na realidade, eu tenho uma sobrecarga muito grande. É esse aqui (Vítor, filho) que eu tenho que cuidar, é marido, é a casa... é o filho que eu te falo que de madrugada eu 
tenho que levar no (nome do lugar onde o filho trabalha), eu tenho que tomar um calmante tarde e eu não consigo acordar cedo. E, às vezes, eu acordo agitada porque 'ai meu deus, eu tenho que ver o Vítor'. Então, eu não tenho aquele sono perfeito, a não ser que eu dormisse com ele no quarto dele."

(Beth, Usuária)

"Porque, às vezes, tem dia que eu acordo tão depressiva, tão triste. Eu não posso assistir um filme mais! É uma tristeza! Que eu já começo a encher meu olho de água querendo chorar. Tudo me faz chorar! Tudo! Até uma novela! Então, menina, é difícil pra mim. [...] Então, porque eu tento mostrar pros meus filhos que eu to bem, que eu to com saúde, tipo assim, que eu vou ser uma mãe eterna. Uma mãezona. Porque eu vejo que minha filha... minha filha fala assim 'Ai, mãe, eu tenho um medo que você morre, porque eu só tenho você mãe'. Uai, agora mesmo, era o quê? Era uma hora, ela veio almoçar e tava chorando. Falei 'Letícia, eu não vou morrer! Olha o tanto que eu sou forte, Letícia!’. Eu sou forte nada, não, bem. No dia que eu fui fazer minha perícia, o tanto que eu chorei! O médico falou que eu tenho depressão."

(Beth, Usuária)

No caso de Beth, a pesquisadora teve a oportunidade de acompanhá-la em uma Consultoria Psiquiátrica, o que traz mais elementos sobre sua história e sobre a conduta da equipe diante da situação. Considera-se que diante da complexa dinâmica familiar evidenciada, a equipe da ESF propõe uma intervenção bastante básica. A ênfase é dada à terapia medicamentosa e à psicoterapia, e as alternativas que transcendem essa lógica são pouco exploradas. Como ajudar Beth a significar seus sintomas para além do diagnóstico psicopatológico? Como auxiliá-la a reorganizar suas tarefas, dividindo as responsabilidades entre os membros da família? Como contribuir para que ela identifique e fortaleça sua rede de suporte social? Como acompanhá-la na adversidade buscando conjuntamente caminhos para melhorar a situação vivida? Tais questionamentos oportunizam um olhar para a pessoa humana, com suas singularidades, dentro de seu contexto, visando à ampliação do cuidado, o que abarca o acolhimento, o encontro de subjetividades, a longitudinalidade do cuidado, a corresponsabilização pelas situações vividas, a solidariedade, a construção de uma perspectiva de comunidade.

c) Regina e Solange

A entrevista com Regina foi realizada na USF, durante sua espera para ser consultada pelo psiquiatra. Ao ser questionada sobre os motivos pelos quais passaria pela Consultoria Psiquiátrica, relatou: 
"Eu comecei a trazer minha mãe, né, que teve uns problemas mais sérios, assim, psicológicos e, aí, como eu já tinha... Eu já não me sentia também tão bem, já começaram a cuidar de mim aqui também. Eu sou uma pessoa meia assim... "meia”, não, inteira tensa, nervosa. Mas, aí, eu to tratando já, com eles já há alguns anos. [...] Eu sempre fui assim só que eu nunca tinha tratado. Antes daqui eu nunca tinha tratado. E algumas probleminhas de sintoma, assim, eu tinha desde criança. Mas, a gente não tinha muita informação, né? Aí, comecei a tratar mesmo agora, depois que eu cheguei aqui.[...] O tratamento é aqui nessa consulta conjunta. Tem o psiquiatra e tem os outros alunos, acho que alunos, residente, né? E ta me ajudando bastante com a medicação. Eu já fiz aqui uma vez com a psicóloga daqui e foi muito bom apesar de não ter sido continuada. Porque não tem muito, né, psicólogos aqui...”

(Regina, Usuária)

Ao longo da entrevista, Regina foi ficando cada vez mais emotiva conforme aprofundava seu relato quanto aos assuntos referentes à dinâmica de sua casa. Chorou bastante e se mostrou muito preocupada em não deixar que a mãe percebesse que havia chorado. "Ela é muito sugestionável e começaria a chorar também” [sic].

“(chorando) Tem hora que eu acho que eu não vou aguentar. Ainda bem que tinha consulta hoje. Porque à vezes não é tão perto. Às vezes, a gente precisa de ajuda mas... Eles não podem atender porque tem muita gente aqui precisando. Mas a gente não quer mostrar esse lado da gente, fraco, entendeu? Foi até bom porque eu falei aqui (na entrevista), se não capaz que eu ia chorar lá. [...] Eu odeio mostrar que eu to fraca, entendeu? A gente tem que mostrar forte."

(Regina, Usuária)

Disse que está sendo muito difícil aguentar tanta coisa calada, sem ter com quem conversar, sem poder comunicar suas fraquezas e frustrações. Relatou que se esforça muito para mostrar-se forte em casa e que isso é muito difícil, pesado. Contou que há muito tempo não desabafava com ninguém e por isso estava tão sensibilizada.

No dia agendado para a entrevista de Solange, a mesma chegou bastante atrasada, pois, segundo ela, precisava fazer o almoço do genro. Sobre os motivos pelos quais está passando em consulta com o psiquiatra, relatou:

“Ela (Regina) não larga de mim. Nem eu também não largo dela. Aí eu fico vendo ela assim... Porque ela não come. Desde pequena que ela foi assim, doentinha, manhosa, o pai dela fazia tudo pra ela, né? Mas ela foi estudando, muito inteligente, né, tudo. 
Aí, quando chega de noite, bate aquela dor da mãe. [...] Voltou aquilo de quando ela era pequena. Aquela preocupação. Aí, à noite, em vez deu dormir, eu fico olhando ela. $E$ u falo 'ai, meu deus, a minha filha ta tão magrinha, ta tão doente. Eu não aguento cuidar dela, né, eu já to ficando cheia de do'. [...] Vai indo eu não aguento mais. Dói muito. Dói muito, muito, muito. Então, a dor é terrível. Da enfermidade. E eu tenho que fazer. Eu tenho que esquecer que eu to com problema nos meus ossos, na cabeça, na carne, tudo. Tenho que cuidar. Porque ela não para. Eu to que nem um trem, sabe, uma Maria-fumaça."

(Solange, Familiar/Mãe de Regina)

Ao final da entrevista, Solange agradeceu pelo espaço concedido para desabafar. Referiu que ia embora pra casa “com menos rugas no rosto" [sic]. Também relatou que a conversa fizera muito bem pra sua filha, que andava muito abatida e, por meio da entrevista, pôde conversar com alguém.

Regina e Solange relataram uma miscelânea de histórias, queixas, desconfortos e desejos, entretanto, observou-se que, novamente, a conduta da equipe limitou-se a procedimentos: consulta, medicação e psicoterapia. Apesar de valorizarem o cuidado que recebem, apontam para a necessidade de mais espaços de diálogo e de interação com a equipe. Observa-se que o próprio momento da entrevista, quando a pesquisadora se colocou à disposição para ouvi-las, foi significado pelas usuárias como uma valiosa oportunidade para “desabafar" [sic], de forma que puderam ir embora para casa "com menos rugas no rosto” [sic]. Infere-se que se as usuárias tivessem a oportunidade de compartilhar e significar suas vivências, através de um contato mais humanizado, integral e continuado tanto com a equipe de saúde quanto com a comunidade, novas e outras formas de interação poderiam ser desenvolvidas, superando a parcialidade da doença, buscando a integralidade da pessoa.

O contato com estas cinco mulheres, aqui apresentado resumidamente através dos relatos, aponta que as questões relativas ao cuidado em saúde mental estão profundamente enraizadas na comunidade e nas redes de relações estabelecidas pelas pessoas. Dessa forma, entende-se que o sofrimento descrito por Amanda, Matilde, Beth, Regina e Solange, não dizem respeito estritamente a elas enquanto indivíduos, mas, sim, a todo o contexto que elas integram, implicando toda a rede de relações das mesmas. Aspectos como o afastamento do emprego, a doença do filho, as relações conturbadas com familiares, entre outros, estão diretamente relacionados ao sofrimento relatado por elas. Infere-se, então, que se tais aspectos fossem mais bem explorados pelos serviços quando estes propõem intervenções, estas tenderiam a ser mais abrangentes e conectadas com o cotidiano das pessoas, considerando que 
o cuidado à saúde mental e o sofrimento mental compõem a vida, compõem a comunidade, interagindo constantemente.

Considerando que as pessoas e as comunidades estão imbricadas com o sofrimento mental enquanto uma condição inerente ao ser humano, tem-se que configura uma difícil tarefa a de distinguir a pessoa "que precisa de cuidados em saúde mental” da pessoa "que não precisa de cuidados em saúde mental”. Assim, no que se refere ao presente estudo, tem-se que quando a pesquisadora se propôs a entrevistar um familiar, este também tinha o seu próprio sofrimento para relatar. A partir dessa perspectiva, torna-se evidente o tênue limite existente entre saúde e doença. Quem é doente e quem é saudável? Quem cuida e quem é cuidado?

Conforme pode-se perceber nos relatos, estar em sofrimento mental não pressupõe incapacidade ou inabilidade, pelo contrário, todas as entrevistadas se posicionaram diante de suas próprias vidas, expondo tanto as necessidades quanto o desejo de superação. Destaca-se que todas as usuárias valorizaram o cuidado recebido, referindo que o suporte proporcionado pela USF é de grande valia. Entretanto, sabendo-se que o campo da saúde pública brasileira, notadamente a Atenção Primária à Saúde, através da Estratégia Saúde da Família, constitui-se um espaço privilegiado de intervenções de cuidado à saúde mental, dada sua proximidade com as famílias e as comunidades, considera-se necessário que as ações neste nível de assistência, transcendam a doença mental e a remissão de sintomas, e se comprometam com a pessoa, visando à continuidade de seu percurso de vida, desenvolvendo e criando continuadamente novas possibilidades de lidar com a loucura e com o sofrimento humano (Dimenstein et al., 2009; Ministério da Saúde, 2005a; Silva \& Cardoso, 2013; Tanaka \& Ribeiro, 2009).

\subsection{Ações: o desafio de cuidar da saúde mental no território}

Esta subcategoria aborda as práticas identificadas pelos profissionais, usuários e familiares como alternativas de cuidado à saúde mental. 


\subsubsection{Consultas, encaminhamentos, internações e medicamentos: o lugar das estratégias tradicionais na ESF}

Ao longo das entrevistas, os participantes abordaram temas relativos às estratégias tradicionais de intervenção, refletindo sobre o lugar das mesmas dentro dos processos de cuidado.

"Assim, a princípio todo paciente que chega aqui, assim, independente da queixa, mas é mais ligado à saúde mental, a gente leva para o acolhimento, né, e assim, quando eu detecto que é alguma coisa, que tem algum sofrimento mental, que tem bastante, né, hoje, a gente geralmente encaminha pro médico, né, mesmo que seja aquele que não tenha vaga, a gente discute o caso, entende? Porque a gente sabe que chega paciente com ideação suicida, né, muitas coisas assim, então a gente nunca manda o paciente embora sem estar passando, né, com o médico. [...] Mesmo que estava deprimido, né, aí a gente também olha no prontuário. Tem paciente que já tem esse quadro, né, que piorou, que faz uso de remédio, que ta sem a medicação, tudo isso a gente olha, né?"

(Andreia, Auxiliar de Enfermagem)

"A gente costuma brincar que Fluoxetina, Sertralina, daqui a pouco eles vão colocar na caixa d'água. (risos). Porque parece... Às vezes, a sensação que a gente tem é que a população inteira parece que... ou antidepressivo ou calmante pra dormir. Quer dizer, é impressionante a quantidade, é muito grande. [...] Eu, particularmente, sou contra, assim, o uso indiscriminado de medicação. [...] As pessoas, é, vai muito na medicação, entendeu? E acham que as medicações também vão resolver os problemas, entendeu? Aqui na saúde da família, a gente percebe assim: muitas famílias às vezes têm conflitos. Quer dizer, hoje em dia, muitos filhos não conseguem cuidar dos pais por causa de conflitos do passado. E as pessoas não conseguem se reconciliar. É impressionante isso. Aí, o que que acontece? Vai pra medicação e acha que a medicação vai resolver os problemas. A medicação não vai resolver os problemas. É importante tomar medicação? Lógico que é importante tomar medicação, só que tem coisa que poderia ser resolvida com um perdão, sabe, com amor, com reconciliação, mas, as pessoas parece que não conseguem. Entendeu? E acaba indo pra medicação. Até que... Talvez até pra esquecer, ou pra amenizar um pouco a falta de amor, a falta de cuidado, a falta de união das famílias. A gente tem muitos casos aqui."

(Carlos, ACS)

"Porque eles não têm apoio, não têm suporte. É o remédio que dá o suporte. E é triste porque você não... você cada vez ta medicalizando mais, né? E quando você medicaliza, você centra no profissional médico. Aí os outros são supérfluos, né? "Ai, o importante é aquele, porque aquele que dá a medicação”.

(Gabriela, Enfermeira) 
"Eu escuto. Porque não tem muito o que fazer. A gente escuta. Aí, dependendo da demanda da pessoa, a gente encaminha ou pra consulta médica, se exige uma demanda medicamentosa. Às vezes a demanda é psicoterapia, só que a gente não tem psicoterapia. Às vezes a gente conversa e depois eu discuto com a psicóloga uma possível visita, assim, eu peço ajuda pra um psicólogo mesmo, pra me dar um apoio. A gente usa muito isso, assim, quando a gente... quando não é medicamentoso, é psicossocial mesmo a questão, a gente pede apoio pra ela. É importante a figura dela na equipe. [...]. Se há necessidade. Se não ela fala 'Ó, aborda isso, tenta falar com ele de alguma forma'. Porque se não, chegou uma época que tava parecendo ambulatório, sabe? A outra psicóloga atendia individualmente, pacientes agendados $e$ que acompanhava várias vezes. E não é o papel da residência deles, o papel da Psicologia dentro da atenção básica.”

(Gabriela, Enfermeira)

"Então, o modelo da Consultoria Psiquiátrica, na realidade, é uma ideia de, vamos dizer, ter serviços onde os profissionais de saúde da assistência primária, do ponto de vista de profissional de nível superior, fundamentalmente o médico e o enfermeiro, que são o núcleo duro em termos de profissional de nível superior da equipe de assistência primária, no caso da Saúde da Família, eles se sentissem a vontade para trabalhar com a questão do sofrimento psíquico e dos transtornos mentais da mesma maneira que eles se sentem a vontade para trabalhar, por exemplo, com hipertensão, diabetes, com a questão de hábitos alimentares, de hábitos de vida relacionados a atividades físicas e etc."

(Mário, Psiquiatra)

Amanda: Mas, assim que o médico chegou ele já me atendeu e foi conversando comigo (se refere à Consultoria Psiquiátrica), perguntando como que era minha rotina, perguntando como que eu me sentia, como tava meu casamento, como eu era com meu filho, com meu esposo. Foi perguntando sobre, assim, da minha vida. E eu fui falando pra ele. Aí ele foi me dando alternativas pra ver a melhor coisa pro tratamento e aí ele marcou retorno agora pro dia 29 de novo. Pra poder conversar, pra ver se melhorou, como é que ta.

Mara: E quais alternativas ele deu?

Amanda: Primeiro ele deu a internação, porque ele falou assim que era melhor ser internada pra fazer o tratamento. Porque no grau que ta já... Tem que ser a internação. Aí eu falei pra ele que eu não ia. Aí, a outra ele me deu a psicoterapia. Aí eu falei que eu também não ia. Aí ele me deu o CAPS, que é pra ir lá, pra conversar, com uma roda de pessoas, psicóloga. E eu falei que eu também não vou. E me deu o (fala o nome do hospital psiquiátrico de internação parcial), que eu ia pra lá de dia e a noite eu voltava pra casa. Aí eu falei que eu também não vou. Eu só vou passar com ele. Eu não quero.

(Amanda, Usuária)

Como pode ser observado a partir dos relatos, tanto usuários quanto profissionais ao abordarem temas relativos ao cuidado em saúde mental, descrevendo as práticas ofertadas ou desempenhadas, frequentemente centraram suas falas em procedimentos, ou seja, consultas, 
encaminhamentos, internação ou medicação. Andreia afirma que ao perceber durante o acolhimento que o usuário apresenta alguma demanda relacionada a sofrimento mental, tenta providenciar um encaixe com o médico, evitando que o paciente vá embora sem passar em consulta com esse profissional. Observa-se uma lógica de trabalho centrada no profissional médico, que acaba sobrecarregado, ao passo que alternativas de interação entre usuário e equipe são pouco exploradas e experimentadas. Neste modelo de atuação predomina, ainda, uma hierarquia entre os profissionais que compõem a equipe, uma vez que fica depositada no médico a responsabilidade por conduzir a situação. Na mesma direção, Gabriela aponta que a centralidade do médico dentro dos processos de trabalho é reforçada, ainda, pelo fato dos usuários frequentemente buscarem na medicação o apoio e o suporte que não encontram nas redes de relações, e, nesse sentido, por ser o único que medica, esse profissional é tido como o mais importante e fundamental.

Carlos, apesar de se dizer contrário ao uso indiscriminado de remédios, observa que cada vez mais as pessoas se utilizam desse recurso como uma alternativa para o alívio imediato do sofrimento. Para Mattos (2001) e Tahan-Santos (2011), o termo medicalização indica um processo social através do qual a Medicina foi tomando para si a responsabilidade sobre um crescente número de aspectos da vida social. Nesse sentido, no modelo de cuidado biomédico, a Medicina não só trata os doentes como, também, recomenda hábitos e comportamentos, apropriando-se da vida privada para sugerir modos de vida mais saudáveis que, supostamente, são mais capazes de impedir o adoecimento. Dessa forma, usuários e profissionais acreditam que existe sempre uma norma a cumprir, um comportamento correto a seguir, esquecendo-se da singularidade das pessoas. Como consequência, é reforçada a lógica de trabalho em saúde centrada em procedimentos em detrimento de uma lógica centrada nas pessoas e em suas necessidades, de forma que possam buscar recursos tanto comunitários quanto próprios para o enfrentamento das situações de vida.

Onocko-Campos et al. (2013) destacam os impactos ocasionados na vida cotidiana das pessoas decorrentes desta cultura de valorização das intervenções médicas como meio para se conseguir transformações de seu próprio eu. Neste modelo, características pessoais são tomadas como doenças, diagnosticáveis e tratáveis como problemas médicos. Quanto mais a Medicina se apropria das condições de vida, mais drogas são desenvolvidas e aprovadas para tratá-las. Observa-se, então, uma distorção do propósito do cuidado. Gabriela, por exemplo, em sua fala, atribui ao remédio a função de “suporte” [sic]. Uma vez que, em virtude da atribulada vida moderna, as pessoas têm dificuldade em estabelecer e manter redes de apoio e de ajuda mútua, a medicação é tida como uma alternativa capaz de proporcionar alívio ao 
sofrimento. Carlos se mostrou incomodado com o fato das pessoas recorrerem excessivamente às alternativas medicamentosas para "resolver” [sic] desgastes familiares. $\mathrm{O}$ Ministério da Saúde (2005b) aponta que, muitas vezes, profissionais e usuários acabam considerando ser mais fácil recorrer aos medicamentos do que conversar sobre os problemas e desenvolver a capacidade para enfrentá-los. Buscam-se soluções prontas, quase mágicas, para questões complexas, relativas à subjetividade humana.

Ressalta-se que este trabalho reconhece o valor da prática médica e os avanços da psicofarmacologia. Problematiza-se, porém, o uso que vem sendo feito desse procedimento, principalmente no campo da saúde mental. Acredita-se que o recurso configura uma importante ferramenta para o controle dos sintomas e que quando associado a outras estratégias como, por exemplo, de promoção de saúde e bem-estar, de socialização, de autoconhecimento, pode contribuir para o estabelecimento de uma condição mais confortável de vida. Para Quinderé, et al. (2013), a centralização da medicação pode ser limitadora da construção dos projetos terapêuticos dos usuários, mas, em muitos casos, este recurso pode potencializar a atuação dos profissionais, familiares e usuários, desde que o uso esteja atrelado ao intuito de impulsionar a autonomia da pessoa, organizando melhor o quadro clínico, mediante o controle da ansiedade, regulação do sono e redução dos sintomas. Assim, segundo os autores, “as intervenções medicamentosas devem ser facilitadoras do processo de autonomia dos usuários e não aprisionadoras, principalmente das questões existenciais, psíquicas e sociais” (p. 2164).

Gabriela, em seu relato, consegue explicitar alguns entraves que impedem a superação das “armadilhas" cotidianas, responsáveis por distanciar o trabalhador das práxis transformadoras. Quando Gabriela afirma que “não tem muito o que fazer” [sic], está se referindo a um sentimento de impotência diante dos casos de sofrimento mental que a paralisa, como se sua possibilidade de atuação frente a esses casos se limitasse à escuta, uma vez que não é possível ir além disso. Diante desse sentimento de impotência, de não saber o que fazer, tem-se que os profissionais lançam mão dos procedimentos, como se buscassem um porto seguro, uma zona conhecida. Dessa forma, esvazia-se qualquer possibilidade de desenvolvimento de novas estratégias, que superem a oferta da consulta, do remédio e do atendimento psicoterapêutico. Gabriela evidencia que existe um desejo genuíno por fazer algo, por fazer diferente e aponta dificuldades para que as práticas avancem para o coletivo, para além dos consultórios. As práticas acabam permanecendo atreladas à lógica de medicar, tratar, curar, transformando, muitas vezes, a Saúde da Família num ambulatório. Desenvolver estratégias transformadoras consiste, então, numa difícil tarefa quando se utiliza apenas de 
ferramentas já conhecidas. Franco e Merhy (2012), considerando o atual debate em torno da mudança do modelo tecnoassistencial em saúde, ressaltam a natureza relacional do trabalho em saúde, atribuindo lugar de destaque ao trabalho vivo em ato. Os autores apontam que apesar do trabalhador da saúde dispor de certo grau de liberdade, muitas vezes acaba capturado pela mecanicidade do cotidiano, impelido a reproduzir a lógica centrada no ato prescritivo, alto consumo de insumos e procedimentos.

Dado este cenário, torna-se importante ressaltar a Consultoria Psiquiátrica como uma das alternativas de intervenção em saúde mental. Compreendida como um passo anterior à implantação do apoio matricial, a Consultoria é uma estratégia desenvolvida a partir de iniciativas da faculdade de Medicina da universidade referência do distrito em que se alocam as USFs participantes deste estudo. A proposta inicial de tal atividade visava atualizar e ampliar a formação dos alunos, tanto de graduação quanto de residência, no que diz respeito às novas políticas voltadas para a Atenção Primária, notadamente a ESF, por meio de inserção dos estudantes na rotina de trabalho das unidades. O trabalho da Consultoria foi iniciado em 1999, dada a disponibilidade do Dr. Mário em dar seguimento a esta iniciativa, a qual era consoante à sua compreensão acerca da importância do fortalecimento da Atenção Primária quanto às questões relativas à saúde mental. Para Jorge, Sousa e Franco (2013), as ações em saúde mental desenvolvidas no âmbito da Atenção Primária exercem papel fundamental ao contribuir com seus saberes para a ampliação do potencial resolutivo das equipes deste nível de atenção, tendo como objetivo a superação da lógica da especialização e da fragmentação do trabalho da própria área de saúde mental.

A fala de Amanda se insere neste contexto na medida em que a usuária relata sua primeira passagem pela Consultoria ilustrando, assim, parte da conduta adotada pela equipe diante das necessidades apresentadas por ela. A usuária descreve as quatro alternativas ofertadas pelo psiquiatra como possibilidades de tratamento, a saber: "Primeiro ele deu a internação [...] Aí, a outra ele me deu a psicoterapia. [...] Aí ele me deu o CAPS [...] E me deu o (fala o nome do hospital psiquiátrico de internação parcial)” [sic]. Destaca-se que tais alternativas reafirmam a lógica explicitada pela enfermeira Gabriela à medida que reproduzem os protocolos e procedimentos que compõem o leque de ofertas do serviço, indicando que apesar do caráter inovador da proposta da Consultoria Psiquiátrica, ainda é evidente a centralidade do saber especializado. Neste cenário, há usuários que acreditam portar uma doença sem cura e profissionais da ESF que não identificam possibilidades de ação desvinculadas do saber especializado, assim, segue-se fazendo mais do mesmo. Nesse sentido, as “novas” maneiras de pensar e fazer saúde parecem relacionar-se à superação das 
“armadilhas” cotidianas, empoderando os profissionais para que não fiquem restritos às formas tradicionais de atuação e continuem, assim, reproduzindo a mesma prática centrada em procedimentos e a mesma crença de que não há mais nada a ser feito.

Campos et al. (2011) presumem a existência de certa propensão dos profissionais da saúde a "darem algo" e não "provocarem algo" nas pessoas que os procuram. A segunda ação parece estar implicada a um processo no qual os profissionais têm a possibilidade de entrar em contato com a subjetividade das pessoas e dos coletivos envolvidos, bem como com sua própria subjetividade, incluindo seus medos, defesas, desejos e resistências, podendo assumir a postura de “apoiar alguém dentro da liberdade de decisão dessa pessoa” (p. 4647), trilhando caminhos que considerem as singularidades de cada situação apresentada.

\subsubsection{A escuta e a conversa como estratégias de promoção e preservação da saúde mental}

Ao longo das entrevistas, conforme ilustram os trechos abaixo, os participantes enfatizaram a importância da escuta e da conversa para a promoção e preservação da saúde mental.

"Estar mais junto dessas pessoas. Porque normalmente, essas pessoas, elas não se abrem com a família, ou elas não têm, né, com quem conversar. E eu acho que ficar sozinho nesse período mais crítico da depressão, acho que só ajuda a piorar. Porque você vê que cada vez que você vai lá, que você conversa um pouquinho, que você dá um abraço, que você toca, faz diferença. Não é só o remédio que cura. Fazer a pessoa se sentir alguém.”

(Catarina, ACS)

"A gente tem muito mais pra oferecer do que a clínica dura que eu aprendi [...] eu acho que a Atenção Primária... é papel da Atenção Primária e é porque... é uma questão de proximidade. O sofrimento psíquico chega primeiro aqui. E eu acho que a gente tem que estar minimamente preparado. E eu não acho que essa é uma preparação difííciil no sentindo que a gente pode começar minimamente ouvindo as pessoas, né, assim, dando oportunidade para que elas falem do que as incomoda, do que as fazem sofrer, né, independente de ter um transtorno mental."

(Miguel, Médico/Coordenador)

"O dr. Mário foi muito bom, assim, pra mim. Eu desabafo. [...] Aí, eu desabafo, aquela raiva sai, vai embora, aí eu vou pra casa, assim, tão leviana, tão leviana, como 
se não tivesse mais nada. Perfeita. [...] Faz bem (conversar). Muito bem. Faz. Ah, e precisa, né? E precisa. E tem muita gente doente, muito, muito mesmo. E eu acho que cada um tem um tipo de doença. Tem uma que corre, que nem eu fui me achar, correr, beber, fiquei 2 anos bebendo. Achando que ia melhorar. Piorou. Mas eu curei... Os médico, né? Eu confiei neles.”

(Solange, Familiar/Mãe de Regina)

"E, ai, filha, sabe, e ultimamente, foi aquilo que eu falei pro psiquiatra, aqui em casa eu não posso reclamar perto da minha mãe. [...] Porque minha mãe fica preocupada com ele, minha filha, meu filho. Então, bem, quando eu vou no Núcleo eu choro até. E quando eu venho aqui (volto pra casa), eu me sinto bem. Então, aquele pouquinho só que eu choro, ou então, eu tenho que chorar no banheiro na hora que eu vou tomar banho."

(Beth, Usuária)

"Na minha atuação, assim, a parte de psicossocial, eu sempre abordo em todas as consultas. Independente do motivo da procura. Então, se ela vem fazer um G.O., a gente tem essa questão, também, do relacionamento em casa, né, então, a gente tenta abordar o aspecto de relacionamento intrafamiliar, de satisfação com a vida, com o trabalho, e, em muitos casos essas mulheres tem algum transtorno de ansiedade, de depressão, que é tratado junto, né, na parte clínica, não necessariamente passando com o psiquiatra. [...] E, talvez, assim, tentar a gente ajudando com ela a reorganizar as ideias, reorganizar, assim, geralmente quando eu pego algum caso assim, eu pego um retorno curto, eu estabeleço com elas algumas coisas talvez que ela possa pensar em mudar, por exemplo, um exemplo que eu tenho de uma paciente que veio de consulta, de rotina. E, aí, ela veio me expor uma situação, uma dificuldade com as filhas, chorou muito, com o filho, né, que usa droga e tudo. E, aí, eu conversei bastante com ela, acolhi, tudo, e falei, e ela não tinha falado nada pro marido, todo sofrimento que ela tava. Então eu tentei primeiro trabalhar isso com ela 'Vamos tentar dividir, vamos tentar conversar com seu marido, né. O que você acha disso?' E, aí, eu marco um retorno curto pra ela. [...] Então, assim, nesse primeiro momento eu tento ser um, mais um suporte, né, acho que até mesmo antes de, lógico, discutir com o médico, sempre, pra ver se não tem risco, se precisa entrar com a medicação. Mas, por exemplo, eu não sei se ela tava no momento deu inserir ela em alguma outra prática, em algum grupo, em alguma coisa.[...] Ela voltou. E ela não tinha conseguido falar com ele (marido), né? E, aí, ela falou mais um pouco, tudo... [...] E assim foi. Mas agora ela mudou (de área). Não ta mais com a gente. [...] E, aí, tem uma coisa muito difícil, também, com a saúde mental, né? A adesão. Geralmente o paciente, às vezes, não tem nem coragem pra sair de casa pra vir no médico. É muito difícil. [...] Saiu da área. Mas, antes disso, ela faltou muito. Faltou com a fisio, eu re-agendei comigo, faltou comigo, a gente fez visita... Muito difícil a adesão. Muito difícil.”

(Fernanda, Enfermeira)

A partir dos relatos, pôde-se observar que tanto profissionais quanto usuários compreendem que a saúde não é conquistada apenas com a remissão dos sintomas, mas também através da possibilidade de partilhar as situações experienciadas uns com os outros. 
Dessa forma, o cuidado é compreendido como uma ação ampla, que transcende a medicalização, o encaminhamento e a realização de exames, abarcando também o fortalecimento dos vínculos entre essas pessoas.

Beth e Solange enfatizaram que o vínculo estabelecido com os profissionais, bem como a confiança depositada na equipe são de muita ajuda para o enfrentamento das adversidades cotidianas. Para ambas, a possibilidade de ter um espaço onde são ouvidas e podem compartilhar as situações vividas, contribui para que se sintam acompanhadas, mais leves e menos sobrecarregadas.

Os profissionais também reconhecem a importância de se colocarem à disposição para ouvir, conversar, estar junto do outro. A valorização e o reconhecimento das estratégias mais amplas e integrais, transcendendo a doença, representam um grande avanço quanto ao entendimento do papel do serviço de saúde enquanto catalisador de estratégias de bem-estar e qualidade de vida, através da consolidação de uma perspectiva de comunidade e de apoio mútuo (Caçapava et al., 2009)

Todavia, em alguns momentos, infere-se que tal compreensão ainda permaneça no âmbito do discurso, não sendo colocada em práticas efetivamente. A enfermeira Fernanda relata que, em sua atuação, tenta transcender a queixa física e abordar os aspectos psicossociais independentemente do motivo que levou o usuário à USF. Todavia, conforme ela apresenta um exemplo prático, percebe-se certa dificuldade em se posicionar ao lado da pessoa. Apesar de valorizar as estratégias de ouvir, conversar, estar junto, ainda mantém a postura do profissional que tem o que dizer e sabe o que fazer. Além disso, observa-se que as estratégias ditas psicossociais ainda são colocadas em prática na perspectiva do consultório, caso a caso. Na situação relatada por Fernanda, a usuária não conseguiu colocar em prática o “combinado" durante a consulta e, após muitas faltas, mudou-se de casa, perdendo o acompanhamento na USF. Fernanda justifica a ineficácia do tratamento proposto através da dificuldade da usuária em aderir às diretivas que lhe foram dadas. Fica depositada no usuário “que não adere” a responsabilidade pelo tratamento, não sendo evidenciado, neste caso, no discurso da profissional qualquer questionamento acerca da própria prática e postura.

Observa-se que os profissionais estão conseguindo escutar, acolher o choro e estar junto das pessoas, todavia, tais ações ainda são colocadas em prática, principalmente, de forma individual, no consultório ou nas visitas domiciliares. Para Fiorati e Saeki (2012), no campo da saúde mental, o modelo biológico, centrado na psicopatologia, e o modelo psicossocial, centrado na pessoa em sofrimento, constituem dois paradigmas conflitantes que integram os atos assistenciais praticados. Para as autoras, trata-se de um processo em que um 
novo paradigma não substitui o anterior mecanicamente, mas durante os períodos transicionais se alternam e se misturam na prática cotidiana das equipes que compartilham determinados objetivos e projetos.

Destaca-se que o processo de transformação das práticas em saúde é lento, pois é resultado de um movimento de reflexões sobre as atribuições dos serviços de saúde, de questionamentos acerca das contradições presentes nas práticas e da elaboração e experimentação de novas ações. Trata-se, portanto, de um árduo trabalho que implica no desenvolvimento de estratégias mais comunitárias e coletivas, investindo em ações que vão além dos consultórios, de forma que a ESF possa contribuir para o desenvolvimento de um território mais saudável. Para isso, o grande desafio é desvelar as “armadilhas” presentes no cotidiano que distanciam o trabalhador de uma verdadeira práxis transformadora, pois vinculam-se a um histórico de atendimento individual, focado na doença e distante do contexto. Assim, apesar dos profissionais se mostrarem interessados e disponíveis para a escuta, a prática ainda é atravessada pelo modelo em que o serviço se apresenta disponível para ser acionado pelo usuário nos momentos de desconforto, quando, então, atua sobre os sintomas visando o alívio imediato, sem que sejam exploradas outras intervenções, mais amplas e comunitárias, para toda a população.

\subsubsection{Vínculo e Cuidado Longitudinal}

Durante as entrevistas, os participantes ressaltaram que o vínculo e o seguimento longitudinal configuram aspectos importantes do processo de cuidado em saúde mental.

“[...] acho que o próprio, a filosofia da Atenção Primária, quer dizer, a gente já conhece o paciente, já conhece a família, esse vínculo que tem, então, eu acho que isso é o diferencial... que quando vem o paciente, você já tem esse conhecimento social, econômico, cultural, enfim, de toda a família, que isso é trazido pelo agente comunitário e pelo próprio vínculo, né, com a família... Então, isso já ajuda muito tratar a saúde mental. [...] Mas eu acho que o que ajuda mais é essa proximidade, é o vínculo, o conhecimento do paciente, o acompanhamento. Isso aí eu acho que é o fator mais importante."

(Maurício, Médico de Família) 
"A porta de entrada é um grupo, uma reunião que nós fazemos com os pacientes, em que a gente procura conhecê-los, saber onde mora, o que eles fazem na vida, o que que... quantos filhos tem, algumas informações da vida deles. [...] Aqui, a gente começa fazendo uma árvore genealógica, da família, e, a gente procura, assim, explorar problemas de saúde anteriores, idade, nome, o que faz na vida, mais detalhado, mais específico de cada membro da família... [...] Nós tiramos a história de saúde, todos os problemas de saúde, nós olhamos o prontuário e tudo aquilo que é importante pro atendimento odontológico, que a gente pode, inclusive apoiar, no seguimento do paciente, a gente acaba contando. [...] Vemos a queixa odontológica, $e$, aí, ta um ponto bastante interessante porque as pessoas, algumas, vem procurando um atendimento de rotina, outras não sabem muito bem, quer fazer um tratamento, acha que tem um problema e, às vezes, tem um problema mesmo. Mas outras não sabem bem o problema que tem. Então, a gente procura trabalhar nesse sentindo, pra que a pessoa possa entender, né, o que ela tem, o que ela gostaria, qual que é o real desejo dela, o que ela realmente ta procurando, né? [...] Concomitante, ou no final desse seguimento aqui, que dura de 4 a 6 semanas, agendamos no (fala o nome da unidade especializada) e lá é feito o cirúrgico-restaurador. Então, quando o paciente chega lá, ele já nos conhece, nós já refizemos ou fizemos vínculos, né, e nós fazemos, assim, o cirúrgico-restaurador."

(Marcos, Dentista)

"Só que a Raquel (médica de família da USF) me proibiu de levar (o filho para o trabalho de madrugada). Então, eu conversando com ele, expliquei o que a Raquel falou, então, eu não to levando todos os dias. Eu to levando só duas vezes. Eu levava todos os dias. Isso tava acabando comigo. [...] Você sabe por que que eu faço isso? Porque ele tem carta, ele tem carro. Porque no ano passado, ele quase morreu duas vezes. Deus não vai dar três vidas pra ele. Deu duas. Ele deu PT (Perda Total) em dois carros. [...] A Raquel lembra da minha história. Ela morre de dó de mim. Porque ele dormiu no volante as duas vezes. E eu fico com medo. A Raquel fala 'Beth, manda ele dormir no pai'”,.

(Beth, Usuária)

Observa-se a partir do relato dos profissionais que os mesmos identificam e valorizam as potências contidas na possibilidade de acompanhar as famílias mais de perto e em diferentes etapas da vida.

Marcos descreve o trabalho do dentista dentro de uma USF, enfatizando que o cuidado à saúde bucal pode estar inserido num contexto mais amplo de cuidados à saúde, não necessariamente atrelado aos equipamentos odontológicos. Seu relato aponta para a potência contida no fortalecimento dos vínculos com os moradores, assim, apesar de muitas vezes os usuários procurarem o dentista da USF com queixas pontuais relativas à saúde bucal, este profissional se vale de todo um conhecimento do contexto e do histórico da pessoa objetivando, por meio de um olhar mais integral, ofertar o cuidado necessário. Ele enfatiza que mesmo o trabalho mais técnico do dentista, ou seja, cirúrgico-restaurador, realizado na 
unidade especializada, é beneficiado pelo investimento nos laços de compromisso e afeto firmados na USF.

Através do relato de um episódio específico, Beth aponta que o fato de Raquel conhecer e acompanhar sua história, fez com que a médica pudesse ajuda-la a desenvolver estratégias para o enfrentamento das situações de vida. Através da parceria constituída, Beth estabeleceu seus limites e reorganizou suas tarefas de forma a se sentir menos sobrecarregada. Muito embora os conselhos da médica tenham sido reproduzidos pela usuária como prescrições, esta considera que o vínculo e o cuidado continuado foram de grande ajuda diante de uma situação complicada. Para Quinderé et al. (2013), o término de uma consulta não deve se limitar apenas a uma receita, um pedido de exame ou um simples encaminhamento. Tendo em vista o caso relatado por Beth, a consulta deve ser o início de um novo patamar de diálogo, a partir da situação da pessoa em sofrimento, suas condições psicossociais e existenciais e seus desafios terapêuticos.

De acordo com Schimith e Lima (2004) e o Departamento de Atenção Básica (Ministério da Saúde, s.d.), o acompanhamento longitudinal, ou contínuo, das pessoas é uma das ações que compete à Atenção Primária e um dos princípios em que se baseia a ESF. As equipes atuam de acordo com o princípio da vigilância da saúde e buscam estabelecer vínculos contínuos entre serviço e comunidade, que perdurem pelas diversas fases da vida. Nesse sentido, tem-se que a perspectiva de um cuidado integral e continuado possibilita que as pessoas integrem a comunidade e se lancem a novos arranjos sociais e institucionais em saúde, a partir de uma compreensão de saúde como direito, pautada no respeito às diferenças e na cidadania. Para Silva e Cardoso (2013), a continuidade da atenção possibilita que o contato entre moradores e profissionais seja constituído de momentos de avaliação e autoavalição dos valores pessoais e regionais, num movimento de abertura e transformação.

Na saúde mental tais conceitos se tornam particularmente importantes uma vez que a Política Nacional de Saúde Mental, apoiada na Lei № 10.216 (2001), pressupõe um modelo de atenção aberto e com base no território, junto às famílias e à comunidade. Para A. Souza et al. (2007), a ESF favorece o atendimento domiciliar, promovendo uma assistência mais humanizada e continuada, com foco na melhoria da qualidade de vida, tendo implícita a promoção da saúde mental e o acompanhamento de usuários e suas famílias nas ações básicas, o que possibilitaria a redução das internações e a (re) inserção social no convívio familiar e comunitário.

Para Arce et al. (2011) o cuidado às pessoas em sofrimento mental pela ESF representa um campo fértil para a afirmação da integralidade do cuidado, impulsionando os profissionais das equipes a desenvolverem ações que corroborem com os pressupostos de 
longitudinalidade do cuidado e fortalecimento dos vínculos, de modo a incorporar nas práticas em saúde, conforme aponta Maurício, o “conhecimento social, econômico, cultural” [sic] a repeito dos usuários e da comunidade. Sob esta perspectiva, a compreensão do cuidado em saúde mental abarca e transcende as intervenções sobre os sintomas, de forma a implicar também um olhar sobre a realidade da pessoa e da comunidade, o que se torna possível através de um vínculo mais efetivo entre profissionais e usuários, que perdure por diferentes etapas da vida. Esta lógica de cuidado parece favorecer o processo de desmistificação da loucura enquanto um fenômeno inexplicável, descolado do contexto e sobre o qual há pouco a ser feito. Esta concepção ampliada da saúde mental oportuniza um entendimento do serviço de saúde enquanto recurso de promoção do bem estar comunitário e de resgate da cidadania. Nesse sentido, tendo em vista os princípios da SUS, especialmente da ESF, e da Reabilitação Psicossocial, as ações em saúde mental, ao serem tomadas como transversais ao serviço de saúde, perpassando todas as práticas, poderiam contribuir para o estabelecimento de relações mais simétricas voltadas à consolidação de uma perspectiva de comunidade.

\title{
5.2.4 O trabalho em equipe como ferramenta para o cuidado à saúde mental
}

Os profissionais apontaram para a importância das reuniões de equipe e da troca de saberes entre os profissionais visando à discussão dos casos.

\begin{abstract}
"Bom, primeira coisa que eu faço é trazer pra equipe. Discussão em equipe na reunião. Aí, a gente estuda estratégias. Eu não tomo decisão nenhuma sozinha. $O$ máximo que eu oriento é que passa em consulta aqui. Eu falo que aqui tem psicólogo e que pode ser encaminhado, mas pra isso tem que passar primeiro pelo médico. É o máximo que eu faço. Não dou orientação pra paciente nenhuma. [...] A única coisa que eu posso ajudar é trazendo pra equipe mesmo, porque, como que eu vou fazer? O quê? Como? [...] Eu não tenho preparo nenhum pra fazer nada por ela. O que eu posso é trazer pra equipe, pra trazer pra médico, pra psicólogo, pra psiquiatra”.
\end{abstract}

(Fátima, ACS)

"Aí a gente procura estar mais perto, né, da pessoa, encaminha, pede pra vir aqui. E, dependendo do que ta na agenda, a gente discute primeiro na discussão de caso, aí o médico que, às vezes, se a agenda ta cheia, ele consegue um encaixe, pra trazer logo essa pessoa. E aí, a gente acompanha mais vezes, né, nas visitas, fica mais perto.” 
"[...] eu acho que é a abordagem multiprofissional que a gente tem, tem outros profissionais de Psico, Fisio, T.O., que ajuda também, Enfermagem, também que ajuda também nessa abordagem. E eu acho que o próprio... nosso também..., eu acho que a nossa... acho que conforme você vai vendo bastante também, você consegue ajudar melhor no diagnóstico, dar tranquilidade."

(Maurício, Médico de Família)

De acordo com os profissionais, no que diz respeito ao cuidado da saúde mental, muitas são as dúvidas e inseguranças despertadas pelo contato com o sofrimento humano. Alguns profissionais referiram que se sentem angustiados e impotentes diante do sofrimento mental. Neste contexto, a possibilidade de estabelecer relações de troca e ajuda mútua entre os profissionais de diferentes áreas do saber, podendo dividir inclusive as dúvidas e reflexões, foi reconhecida como estratégia potente de fortalecimento da equipe para o enfrentamento das demandas por cuidados em saúde mental.

Entretanto, observou-se também que, contrariamente à proposta do trabalho em equipe, o recurso de “trazer pra equipe” [sic] pra discussão em conjunto, em algumas situações, pode acabar se conformando como uma alternativa de desresponsabilização pela situação, repassando para o outro (ou outros) a responsabilidade sobre determinada situação da qual não se dá conta. Fátima, em seu relato, é enfática ao afirmar que não sabe como ajudar determinada família e, diante da situação, a única possibilidade da qual dispõe é levar o caso pra equipe. Desse modo, observa-se que a atuação se restringe a identificar e repassar os casos, não havendo uma responsabilização, como se seu trabalho se encerrasse após a situação ser reportada à equipe. Ao acreditar que o caso não é de sua alçada, Fátima se distancia e repassa para outros a tarefa (e a angústia) de pensar sobre uma possível intervenção, reforçando a fragmentação dos processos de trabalho e a centralidade do especialista. Questiona-se, assim, o que poderia ser feito neste espaço visando empoderar Fátima para que ela reconheça e/ou desenvolva as ferramentas necessárias para o cuidado em saúde mental. Infere-se que o fato dos profissionais terem apresentado dificuldade em indicar para a pesquisadora os usuários que recorrem às USFs devido a queixas de sofrimento mental constitui uma consequência desta sensação de impotência e insegurança frente a tais situações que, conforme observado, pode acarretar o distanciamento e a desresponsabilização pelos casos.

O processo de trabalho em equipe na ESF é fundamental para a busca permanente de comunicação e troca de experiências e conhecimentos entre os integrantes da equipe e destes com a comunidade (Ministério da Saúde, 2010). De acordo com o Departamento de Atenção 
Básica (Ministério da Saúde, s.d.) os profissionais da ESF, enquanto equipe, têm o papel de estabelecer vínculos de compromisso e de corresponsabilidade com a população; estimular a organização das comunidades para exercer o controle social das ações e serviços de saúde; utilizar sistemas de informação para o monitoramento e a tomada de decisões; atuar de forma intersetorial, por meio de parcerias estabelecidas com diferentes segmentos sociais e institucionais, de forma a intervir em situações que transcendam a especificidade do setor da saúde e que tenham efeitos determinantes sobre as condições de vida e saúde dos indivíduosfamílias-comunidade.

No que tange à saúde mental, segundo Minozzo e Costa (2013), o trabalho em equipe é um recurso determinante para o rompimento das práticas asilares, atuando como uma das formas de enfrentar a fragmentação do trabalho e da pessoa, visando a integralidade do cuidado. Nesse cenário, a equipe é entendida como um dos atores principais no processo de construção de um novo modelo de atenção à saúde mental, mais plural e integral.

\subsubsection{Desenvolvimento de estratégias coletivas e apropriação de espaços comunitários}

Esta subcategoria aborda a compreensão dos entrevistados sobre as estratégias coletivas ofertadas pelas USFs e sobre os espaços comunitários que compõem o território e que podem ser apropriados pela comunidade como cenário de troca e convivência.

“E, aí, faz os grupos, também, eu to participando do grupo de vivências, que é um grupo pra estimular isso mesmo, assim, aumentar o apoio social, promoção de saúde mental. Então, a gente fica costurando, pintando, super gostoso, assim! Aprendi a costurar. A gente, assim... a ideia é a gente ensinar elas a fazerem coisas, mas, assim, um monte de velhinha, ensinar elas a costurar, até parece! A gente que acaba aprendendo, assim. É... [...] Então, normalmente a gente falou, assim, na discussão de... na reunião administrativa pra chamar pessoas que são, assim, ociosas, que tão em depressão e não sai de casa pra nada, sabe? Só que acaba que essas pessoas não querem vir, né? Então, a gente chama, assim, mais quem ta com demanda de... que você vê que ela quer aumentar a rede de apoio, assim, dela, mas não tem familiar, não tem com quem contar. Então, a gente traz pro Núcleo e faz elas se conhecerem, assim, sabe?” 
Mara: E como você acha que esse grupo pode ajudar?

Raquel: Ajudar o que? Eles? Ah, na verdade, no cuidado mesmo. Como manejar isso... Porque a T.O. vai ta junto e a Psicologia vai ta junto com a gente. Então, o que que nós vamos colocar? Nós não vamos colocar os temas fixos, eles vão trazer os temas e eu acho que nós vamos deixar eles ventilarem um pouco, colocarem suas experiências, vendo a experiência do outro, que não é só ele que passa por aquilo, o outro também passa... aprender a respeitar o colega... porque eles têm problema até de limite, eles vem pro grupo e eles querem todos falar, falar, falar. Então, respeitar a vez do outro, ver que o outro também tem essa necessidade. Eu acho que vai ser bem legal. Vai ser... Pelo primeiro encontro, a gente vê que vai ser rico!

Mara: Uhum. Parece um espaço interessante. Tanta queixa de solidão, tristeza, é interessante um espaço pra compartilhar.

Raquel: É, eu acho que eles vão poder compartilhar.

(Raquel, Médica de Família)

"Nós fizemos uma festa julina agora em julho, devia ter umas 500 pessoas. Só pra você ter ideia, a gente fez uma festa julina, nessa festa nós arrecadamos quase 4000 reais líquido. [...] Que que a gente faz? A gente pega esse dinheiro depois, durante o ano, a gente faz outros eventos com essa própria população. Dias das crianças, festival da saúde, a gente faz outros pequenos eventos, tal. Pra trazer essa população pra cá, tal. [...] A gente tem uma certa dificuldade, às vezes, de trazer a população pra cá. Mas, sempre vem. Grupo de hipertensão, de diabetes. Mas, tem esses grupos, a gente ta sempre querendo... Grupo de gestante foi tentado semana passada. Essa semana foi tentado fazer um grupo de amamentação. Mas, aí, vem uma mãe ou outra porque acho que a gente tem 4 ou 5 gestantes só. Então...[...] Grupo de saúde mental... A Tereza faz um grupo de artesanato. E o pessoal da Casa Terapêutica que são pacientes que tem... de saúde mental, eles vêm aqui, participam, tal. [...] A gente tem pensado em outras estratégias. Porque se você, por exemplo, a gente chama as pessoas aqui pra falar de hipertensão, de diabetes, muitas pessoas às vezes não vêm porque eles não gostam muito de falar de doença. Então, a gente tenta mudar um pouco o foco, entendeu? E se você chamar aqui pra dar uma aula, às vezes eles não gostam. Então, às vezes vem pra contar a experiência de vida de cada um. Aquele que controla bem acaba estimulando aquele que não controla... [...] A gente tem essa experiência. Aquele que usa insulina mostrar pra aquele que não usa que não é o fim do mundo...[...]A gente tenta outras estratégias, entendeu, pra trazer, tal. Mas, às vezes, é difícil você trazer as pessoas pros grupos, assim, porque normalmente, são as mesmas pessoas que participam. Como aqui tem 10, aqui tem 11, 12 anos aqui tem, às vezes, você fica convidando as mesmas pessoas pras mesmas coisas todo ano. Isso também vai cansando, entendeu, a própria população, você vai perdendo, aí, a adesão. Mas, a gente ta sempre tentando mudar as estratégias. Agora a gente ta pensando em fazer um bingo. Idoso gosta muito de bingo. Faz um bingo aqui pra trazer eles pra passar uma tarde. Nós já fizemos baile, já fez carnaval na parte da tarde, filme. Às vezes, coloca um filme super interessante, assim, pra discutir alguma coisa. Né? Você quer discutir um assunto, coloca um filme que vai aparecer aquele assunto ali, aí, depois, acabou o filme, você bate um papo, uma pipoca, um refrigerante, tal. São tentativas, né, de...[...] Porque se você focar muito na doença... E é ruim mesmo, né? Ninguém quer ficar falando só de doença. É por aí..."

(Carlos, ACS) 
“Essa moça mesmo, nós pegamos uma parente dela, que também tinha depressão [...] 'Eu sei o que ela ta passando. O que ela ta passando, eu já passei por isso. Hoje eu posso ajudar ela' E eu fui e conversei com ela, pra ela dar espaço pra outra estar junto dela e eu acho que foi legal para as duas. Elas são primas... ou não sei se os maridos que são parentes. E foi bom. Uma porque já passou e a outra porque tava (passando)."

(Catarina, ACS)

“Eu acho que precisa de mais atividades coletivas! Do que só o individual. Será? Né? Que nem eu te perguntei. Será que vai resolver. Todo mundo vai fazer psicoterapia individual, será que só isso? Se o indivíduo continuar sozinho, só fazendo psicoterapia, também não vai ajudar. Ele precisa sair, ele precisa interagir. Eu acho que precisaria ter estratégia coletiva, sim, lazer... Talvez isso... Não sei também, né? (risos) [...] E a gente gosta de grupo, né, eu nunca vi, a gente gosta, principalmente esse Núcleo. A gente adora grupo. [...] Então, a gente já percebeu, assim, se for pra ficar dando aulinha 'então, vamos lá, o que é hipertensão?'... Eles não vêm! Aí você fala assim 'e se oferecer alguma coisa?' Às vezes a gente faz um lanchinho. Também não vem. Quer dizer, não adianta você oferecer um lanchinho... Né? A gente ta tentando, assim, pensar: 'o que faz tocar o paciente? o que faz ele vir?'”

(Raquel, Médica de Família)

Mara: E são pensadas estratégias mais coletivas pra cuidar da saúde mental?

Fernanda: Temos. Então, nós procuramos inserir os pacientes de saúde mental no grupo de caminhada pra eles terem uma atividade física, né, e ter os benefícios da socialização com outras pessoas. A gente começou também um grupo de... de... de vivências, que chama, que é um grupo também pra... pra experienciar um... um pouco de conversar do dia-a-dia, um pouco de atividades de vida diária. Elas tão fazendo agora, tão num momento de fazer artesanato, tapete, vão montar uma... uma barraquinha no dia das crianças pra poder expor o que elas tão fazendo. [...]

Mara: E tem adesão?

Fernanda: Tem. Do grupo de caminhada tem uma adesão maior, né, porque o público, assim, também, é um pouco mais aberto. Do de vivência, eu acho que ta vindo 3 pacientes. [...] É pouco. É muito pouco, mas o convite é um monte que se faz. Mas é muito difícil. Hoje eu tava discutindo com o Dr. Maurício isso. Que, às vezes, a gente vai cansando porque a gente sabe que é importante, promoção e prevenção, mas parece que a população não quer, ou não entende, assim, sabe? Então, pra eles quanto mais consulta, vaga de consulta tiver aberto, isso é um motivo de satisfação. Mas esse tipo de coisa parece que não gera, sabe, valorização, assim. Porque a gente convida e é todos os grupos, de diabetes, a gente convidou 30 pessoas, veio 3.

Mara: Porque será?

Fernanda: Eu acho que culturalmente, ainda, eles... eles ainda não têm, assim, isso como, acho que talvez não tinha tantos grupos, não tinha tantas oportunidades, então, as pessoas ainda não... Né? Acho que vários fatores. Acho que não entende isso como processo de saúde. Acho que... Ai, acho que a questão quando bate no auto-cuidado ela é um pouco mais delicada, né? Quando a pessoa tem que pensar que ela é protagonista da sua saúde. Eu acho que isso é um pouco difícil das pessoas entenderem, né, que a porcentagem dela é muito importante. E quando a gente trabalha esses grupos, a gente tenta trabalhar isso... autonomia, mudança de estilo de vida, né, e acho que isso é um pouco difícil ainda. Não sei. São hipóteses. Aí eles 
falam um monte, é tempo, é... “Ah, não tem ninguém pra ficar com meu filho”. Tem vários empecilhos, né?

Mara: Eles mesmos entram numa lógica de só procurar o Núcleo quando...

Fernanda: Quando precisa, quando ta doente, né? Então, assim, é meio complicado. Mas a gente não pode desistir, né? Tem que continuar tentando e valorizando cada vez mais... é isso que a gente tenta, assim. O próprio fato do médico estar nos grupos, né, isso valoriza o grupo “Poxa, o médico ta aqui”. Né? Pra eles é importante, né?

(Fernanda, Enfermeira)

"Se fosse sozinha conversar, tudo bem. Mas com 4, 5, 6, não. Eu não ia. [...] Pra mim não ia resolver. Não ia porque eu não ia (risos). Eu não ia frequentar. [...]. Será que as pessoas não têm problemas pra resolver, então (não vão)? [...] Eu não sei se eles têm que mudar alguma coisa, se tem que acrescentar alguma coisa... [...] De repente, a pessoa não quer participar de um grupo. Como eu não iria. Se eu tivesse precisando, eu não ia. Né? De repente as pessoas não querem participar. Porque eu acho o seguinte... eu acho assim... o que é falado tem que ficar ali. Eu vou ser sincera: não fica. Hora que você sai 'Ai, você viu? A fulana tava lá.' 'Você viu a fulana?'[...] Às vezes seria... Seria assim: chamar a pessoa que ta com problema, no caso lá eles, né, chamar a pessoa que ta passando por um problema, e tentar resolver, não sei... nem que fosse 15 minutos... A cada uma vez por semana, 15 minutos cada duas... duas vezes na semana. E um diálogo só paciente e médico.”

(Matilde, Familiar/ Sogra de Amanda)

Observa-se que ambas as USFs desenvolvem atividades coletivas, algumas situadas como de promoção de saúde e prevenção de agravos, outras com o objetivo de atuar sobre uma enfermidade específica. Os entrevistados falaram sobre o tema através de descrição das atividades que realizam, evidenciando a forma como significam a realização das mesmas dentro do contexto da ESF, explicitando as potências e dificuldades encontradas no processo. Demonstraram, ainda, a compreensão de que as estratégias coletivas constituem possibilidades de cuidado tanto da saúde mental, quanto da saúde como um todo.

Raquel e Ana Paula, cada qual vinculada a uma USF, fazem referência a uma atividade grupal da qual participam. Ana Paula descreve um grupo cujo objetivo é promover saúde mental e aumentar a rede de suporte social, através do oferecimento de um espaço em que as pessoas que moram sozinhas, sem família, com poucos compromissos fora de casa, possam se conhecer e conviver. Destaca-se que apesar de uma das propostas do grupo, segundo a entrevistada, ser a promoção de saúde mental, ela faz a ressalva de que a atividade não atinge a população alvo, que seriam as pessoas “ociosas, que tão em depressão e não sai de casa pra nada” [sic]. Este fato, apesar de reconhecido por Ana Paula, não é suficiente para avançar em direção a outras possibilidades de cuidado na comunidade. 
Observa-se que Ana Paula se coloca como sujeito integrante do grupo, beneficiando-se do contato com outras pessoas. Já a fala de Raquel evidencia certo distanciamento entre os profissionais e os usuários que participam do grupo. Para ela, o grupo é uma oportunidade para que as pessoas convivam, aprendendo com as experiências uns dos outros, exercitando o respeito ao próximo. A médica considera que se trata de um espaço interessante em que “eles” [sic], os usuários, podem se beneficiar do convívio com outras pessoas. Infere-se que Raquel, para esta atividade, preserva a postura de profissional, aquele que sabe o que é bom para o outro, não se colocando como pessoa integrante do grupo, detentora de suas conquistas e fraquezas, capaz de estabelecer trocas e também de se beneficiar do convívio com outras pessoas.

Carlos e Catarina, ambos agentes comunitários de saúde, destacam outras estratégias, além dos grupos, que visam desenvolver a convivência entre as pessoas da comunidade, constituindo importantes alternativas de cuidado. Catarina relata um caso em que investiu na aproximação e na criação de vínculos entre duas pessoas da comunidade: uma que já havia enfrentado um período de depressão e outra que estava passando por um momento difícil. Catarina percebeu a potência contida no contato interpessoal, em que uma pessoa se abre para o contato com a outra, permitindo-se ajudar e ser ajudada, numa perspectiva de solidariedade e de consolidação da comunidade. Carlos menciona uma série de estratégias desenvolvidas visando a interação entre as pessoas da comunidade, são elas: bingo, baile, festas, datas comemorativas, carnaval e exibição de filmes. Para ele, estas estratégias consistem em tentativas de promover atividades que não tenham a enfermidade como foco, uma vez que "ninguém quer ficar falando só de doença" [sic]. Nesse sentido, ele acredita que a forma como os grupos são pensados e propostos, ou seja, pautados nas doenças e em formato de aula expositiva, consiste na principal razão pela qual a comunidade não tem aderido a estas atividades. Soma-se a isso o fato dos grupos acontecerem em ciclos que se repetem periodicamente, de forma que assistir ao mesmo conteúdo deixa de ser atrativo para as pessoas.

Raquel, em outro trecho, apresenta uma reflexão pouco amadurecida acerca do papel da Psicologia, como se esta tivesse como ideal que cada pessoa fizesse sua psicoterapia individual. Ao reconhecer o valor das estratégias coletivas e os benefícios da socialização, a médica questiona se a psicoterapia individual para todos, sem a promoção de espaços de interação, traria bons resultados para a sociedade. Ao abordar a questão, reduz a realização de estratégias coletivas aos grupos promovidos pela unidade, não explorando alternativas para colocar a comunidade em relação. O grupo acaba se constituindo como mais um procedimento do qual a equipe lança mão; embora visem desenvolver estratégias mais 
dialógicas e comunitárias, acabam reproduzindo a lógica de que o profissional tem um saber que deve ser passado. Ao se referir à maneira como são pensados os grupos, Raquel revela “ $A$ gente ta tentando, assim, pensar: 'o que faz tocar o paciente? o que faz ele vir?’” [sic], evidenciando que a comunidade não participa deste processo de construção do espaço coletivo, para o qual poderia contribuir com propostas de atividades e temas de interesses, respondendo às questões da médica.

Fernanda também acredita nos "benefícios da socialização com outras pessoas" [sic] advindos das estratégias coletivas. Entretanto, diferentemente da perspectiva de Carlos, acredita que a população tem dificuldade em aderir às propostas de grupo devido a, culturalmente, não terem o hábito de se inserir nesse tipo de atividade. Para ela, os usuários dão pouco valor às atividades de promoção e de convivência, recorrendo ao serviço apenas nos momentos de agudização, o que reflete certa dificuldade das pessoas de se colocarem como protagonistas de sua saúde e, consequentemente, como corresponsáveis por sua condição. Destaca-se que o formato e o propósito dos grupos, bem como as estratégias utilizadas para convidar os usuários, não foram questões levantadas pela enfermeira como possíveis aspectos que interferem ou determinam a relação que a comunidade estabelece com estas atividades. Assim, observou-se um movimento em que a população acaba sendo culpabilizada pelo esvaziamento das atividades coletivas propostas pela USF.

Matilde, sogra de Amanda, que também é usuária da USF, é enfática ao afirmar que não tem nenhum interesse em participar dos grupos oferecidos pelo serviço de saúde. Para ela, os grupos abordam assuntos particulares dos moradores e, muitas vezes, as informações acabam circulando na comunidade. Matilde questiona, então, se a não adesão a essas atividades estaria relacionada a não correspondência das mesmas a uma real demanda da população. Corroborando com a percepção de Fernanda, Matilde mostrou atribuir grande valor à consulta médica e aos momentos de diálogo entre médico e paciente.

Destaca-se que a valorização das estratégias coletivas por parte dos profissionais das USFs estudadas representa um grande avanço na direção da consolidação de um cuidado mais abragente e integral, pautado na perspectiva do fortalecimento da comunidade. Trata-se de um processo lento e trabalhoso, que se dá na medida em que as novas formas de fazer saúde são experimentadas, reformuladas e aprimoradas. Transcender as estratégias tradicionais, pautadas na terapêutica, é um grande desafio que implica em criatividade, tolerância à frustração e capacidade para identificação das necessidades.

Diante dos relatos apresentados, infere-se que é necessário que sejam exploradas novas alternativas que promovam a interação entre os membros da comunidade, e destes com 
o serviço de saúde. Mais do que uma estratégia de benefício à saúde mental, objetiva-se a consolidação de um serviço “de saúde” e não “de doença”, com espaço para o exercício da cidadania e da solidariedade, possibilitando a construção de novos contratos sociais que apontem para o resgate das singularidades e do respeito às diferenças (Silva, 2011; Minozzo, Kammzetser, Debastiani, Fait \& Paulon, 2012). Neste cenário destaca-se a incipiência de estratégias de apropriação dos espaços comunitários e de estabelecimento de parcerias com outros equipamentos, conforme indicam os relatos abaixo:

"Aqui a gente dificuldade com espaços comunitários. [...] A gente tem o Programa de Integração da Comunidade, que faz as atividades aqui dentro, né, pra comunidade. E, assim, no bairro a gente não tem muita coisa. O pessoal às vezes vai na igreja fazer atividade, mas não tem muita opção. [...] A gente ta agora tentando fazer uma Comissão Local de Saúde. Já teve no passado, mas desde que eu cheguei aqui não existe mais. Mas a gente percebe, assim, que a população ta um pouco afastada, sabe, dos grupos, das coisas... Então, a gente ta tentando pensar quais estratégias nós vamos usar pra trazer a população pra nos ajudar nos grupos... Quando a gente fez a festa junina, a gente fez PARA a comunidade e COM a comunidade. Mas a gente não tem... a gente tem visto que a comunidade ta afastada, não ta participando... A gente ta querendo entender... Porque? O que que ta faltando? E mostrar pra eles, assim, que fazer a Comissão Local de Saúde é pro nosso próprio benefício. É pro bairro, é pra gente. Só que a gente já tentou fazer uma reunião e vieram dois moradores. É muito difícil! As pessoas querem as coisas, mas, na hora de ir a trás, de lutar por aquilo, dar a cara a tapa, aí ninguém quer. [...] Todo mundo quer o espaço, todo mundo quer, mas não participa da construção. Mas não tem muita coisa, não.”

(Raquel, Médica de Família)

"Bom, eu acho que tem os grupos, né, que eu falei, o grupo de caminhada eu acho que é o principal, assim, que tem, porque é o que mais vem gente. Vinte e cinco pessoas, assim.[...] E... Acho que assim, tem a praça aqui na frente, que é uma coisa que a gente tenta usar só que ta, assim, não ta sendo utilizada e vem as pessoas fazerem tráfico aqui, então, daí uma coisa leva a outra... [...] A praça ta sendo deixada de lado. A gente ta começando a fazer também agora, é que isso não é muito saúde mental, mas me veio, é a Comissão Local de Saúde aqui do Núcleo só. E ta vindo pouco gente, tem três pessoas só por enquanto mas a gente ta tentando multiplicar, assim. E, aí, só que, assim, eu acho que tem um pouco a noção de saúde mental porque a pessoa vem falar sobre o que ela ta achando do Núcleo e do... da comunidade mesmo, né? [...] E mesmo porque, principalmente o que a gente mais pega nessa questão das pessoas se conhecerem e terem contato com outras pessoas, a gente já reparou que essas três que vem elas tão super juntas agora, participam de tudo, assim, sabe? Acho que é um espaço importante pra eles se darem conta da importância, também, que tem a participação.”

(Ana Paula, Residente de Psicologia) 
Mara: E você acha que existem espaços comunitários...

Maurício: Em outros serviços, aqui da comunidade? Eu acho que sim, sempre, né, a própria igreja. Tem uma associação de moradores, mas não é bem aqui na nossa área também, fica próximo aqui ao (fala o nome de outra USF), mas que a gente já fez trabalho, eu acho que tem várias coisas, né, e a maior de todas, nossa, que é a (fala o nome da rua da favela), né, que é a comunidade, né, favela, a área de favela que a gente tem que também é bem importante, né, as condições socioeconômicas, de stress, de álcool e drogas, violência, enfim, então, também é uma área que é importante. Não chega a ser um equipamento, mas é uma área de vulnerabilidade. Que a gente vira e mexe sempre ta trabalhando com alguma coisa, né, de prevenção, DST, gravidez precoce, enfim, sempre tem coisas assim...

(Maurício, Médico de Família)

“E, assim, essa região aqui, não oferece, não tem um centro de lazer, não tem, assim, tem alguns locais tipo igreja com trabalhos manuais, mas, com horários, às vezes, inviável, que não tem muito contato com essa realidade da comunidade, às vezes é aquele espaço muito fechado pras pessoas que são membros, ali, da igreja. Então, isso nem é tão divulgado. Assim, talvez se tivesse centros de atendimento que ali eles fossem aprender a mexer com computador, pintar, bordar, dançar, que fosse um ambiente que eles tivessem tudo isso. Mas, pelo o que eu sei da Casa Terapêutica, eles tem acesso a.... uma vez por mês, eles vão ao centro da cidade, compram roupas, vão tomar sorvete, vão almoçar fora, mas, assim, o que se diz em termos de socialização, ainda é pouco. É pouco. Mas já é um passo.”

(Cínthia, Auxiliar de Enfermagem)

“Olha, a igreja é uma parceira importante aqui pra gente, a igreja católica... [...] Então, é, parceria com as pastorais, é... pastoral da saúde, pastoral da criança... Nós temos a escola, embora não esteja na nossa área de abrangência, a gente tem tido uma parceria bem legal, né, a gente começou no ano passado, inclusive com os alunos da graduação, que às vezes não estão o tempo todo aqui, né, como os profissionais da equipe mínima, mas quem tem uma inserção semanal, então de desenvolver alguns projetos. No ano passado, a gente construiu um projeto de intervenção junto com os professores pra conversar sobre álcool e drogas... Foi bem legal!”

(Miguel, Médico/Coordenador)

Mara: Você acha que no bairro, ou na cidade, tem outros espaços que, assim como a academia, possam fazer bem pra sua saúde?

Amanda: Que eu me interesse, não. O Dr. Maurício me aconselhou o yoga. Pra mim tentar fazer yoga que, às vezes, ia me ajudar bastante. Só que eu não conheço nenhum lugar que tenha yoga a não ser você pagando. Então, eu acho que se ele aconselhou isso, eu acho que devia ter um espaço, um lugar pras pessoas que não tem condições de pagar, fazer. [...]

Mara: Tem outras atividades que você pensa?

Amanda: Não. Acho que não.

(Amanda, Usuária) 
A partir dos relatos, é possível observar que a compreensão dos entrevistados acerca dos espaços comunitários é bastante diversa. Ao serem interrogados, os participantes fizeram referência a uma série de espaços físicos ou atividades específicas que podem ser significados como recursos de promoção da convivência comunitária. Atividades como a festa junina e o grupo de caminhada, ambas organizadas pelas USFs, foram significadas como espaços comunitários a serem apropriados pela população, evidenciando uma compreensão do serviço de saúde como um local potente de convívio e apoio mútuo. Silva e Cardoso (2013) destacam o potencial das comunidades para promover o desenvolvimento da pessoa, por meio do estabelecimento de relações de solidariedade e de abertura de uns para os outros, proporcionando a formação de vínculo e o sentimento de pertença a um grupo.

As iniciativas vinculadas a outros equipamentos sociais tais como igrejas, associação de moradores, escolas e pastorais, embora valorizados enquanto recursos reais e potentes, ainda parecem relativamente vagas e incipientes. Segundo J. Souza et al. (2013), para que sejam alcançados os princípios propostos pelas políticas de saúde pública e saúde mental, é necessário transpor os limites do modelo biomédico e desenvolver parcerias entre os diferentes segmentos sociais, uma vez que os dispositivos comunitários constituem importantes fontes de suporte social e podem contribuir para a melhoria das condições de vida da população. Neste contexto, tais propostas intersetoriais implicam no reconhecimento dos recursos disponíveis no território, oportunizando que estes sejam empregados como ferramentas nos planos de cuidados elaborados.

Mielke, Cossetin e Olschowsky (2012) destacam que os recursos da comunidade são fundamentais para que sejam alcançados resultados efetivos no processo de Reabilitação Psicossocial de pessoas em sofrimento mental. Ao encontrar serviços e atividades capazes de acolhê-lo e inclúí-lo, o usuário passa a ser reconhecido pela sua comunidade, ao mesmo tempo em que reconhece a si próprio como parte dela, oportunizando sua atuação enquanto cidadão com direitos e deveres na luta pela qualidade das ações em saúde.

Nesse sentido, Ana Paula destaca a praça como um recurso do território que poderia constituir um espaço de encontro e convivência, podendo, inclusive servir de cenário para algumas atividades da própria USF. Todavia, a entrevistada faz a ressalva de que este espaço está sendo utilizado para compra e venda de drogas, o que afasta a população e dificulta o uso recreativo do local. Questiona-se se o uso da praça para comércio de drogas é significado pelos profissionais da USF como uma demanda de saúde deste território a ser pensada e apropriada pelo serviço enquanto uma questão da comunidade. 
Raquel e Ana Paula fazem referência ao processo, em fase inicial, de organização das Comissões Locais de Saúde. Ambas as entrevistadas apontaram este recurso, embora pouco consolidado em seus territórios, como uma estratégia potente no que se refere ao fortalecimento comunitário. As Comissões Locais de Saúde atuam respaldadas por legislação municipal (Lei $N^{\circ}$. 5972, 1991), em conformidade com as leis que regem os Conselhos Municipais de Saúde (Lei Nº. 8142, 1990; Lei Nº. 8080, 1990), prezando pela participação da comunidade na organização, gestão, fiscalização e controle do SUS. Trata-se de instâncias colegiadas, autônomas, de caráter permanente e deliberativo no âmbito local, cujo objetivo é garantir a participação dos usuários, funcionários e gestores nos processos de gestão da saúde e controle das ações e serviços da unidade de saúde. Cabe aos conselheiros locais a realização do acompanhamento das atividades das unidades de saúde, discutindo os problemas, propondo ações e avaliando a qualidade e resolubilidade das mesmas. De acordo com Mielke et al. (2012) e Luz (2001), a participação de usuários, profissionais e gestores nos espaços decisórios referentes às políticas sociais, para além de um direito assegurado pela Constituição de 1988, caracteriza-se como um campo de ação que fortalece reais dispositivos para o atendimento das necessidades no território e proporciona o exercício da cidadania.

Ana Paula, tomando como exemplo os três usuários que integraram o processo de organização da Comissão Local de Saúde, demonstrou compreender tal espaço como uma ferramenta de promoção de saúde mental. A equipe observou que estes usuários encontravamse mais próximos, convivendo mais, o que, provavelmente, potencializa o engajamento e a apropriação desses espaços. Para Luz (2001), as relações de solidariedade e cooperação tendem a tornar-se o ponto de partida para a renovação da sociabilidade, para a constituição de "novos amigos", para o estabelecimento de trocas de diversas naturezas, que vão, aos poucos, restaurando o tecido social comunicativo através da criação e extensão de atividades para fora do âmbito das práticas de saúde.

Já Raquel expõe a dificuldade de implicar a população nas atividades da USF, diante da constatação de que a comunidade “ta afastada, não ta participando” [sic]. Destaca-se a iniciativa da médica de se aproximar dos usuários na tentativa de compreender os motivos pelos quais a população não participa mais ativamente desses espaços, uma vez que existe interesse pela melhoria do serviço. Para Mielke et al. (2012) a dificuldade de apropriação destes espaços pela população pode estar associada às interferências de cunho político, especialmente as neoliberais; à lógica de resolução imediata dos problemas, através da qual os serviços são acionados apenas nos momentos de desconforto; à descrença da população no sistema de saúde devido à sua burocratização; à formação insuficiente que a população possui 
para compreender seu papel nos processos que envolvem o controle e a participação social. A partir deste contexto, os autores consideram que os profissionais têm papel fundamental em incentivar a participação popular nos serviços de saúde como forma de fortalecer o SUS, ampliando o acesso às informações de cunho teórico-político da legislação e dos movimentos sociais, dando voz às demandas da comunidade e propondo a corresponsabilização para a busca de resultados. E dado este panorama, a Comissão Local de Saúde é compreendida como potente espaço de reflexão e educação, visando o favorecimento da cogestão institucional.

Observou-se, também, por meio dos relatos, que a perspectiva de alguns entrevistados acerca da identificação e apropriação dos espaços comunitários pela população é relativamente vaga, confusa, abrangendo desde as áreas de favela como possíveis recursos de convivência comunitária até a proposição de “centros de atendimento” [sic] que oferecessem aulas de computação, pintura, bordado, dança. Evidencia-se uma reflexão pouco amadurecida acerca dos recursos existentes no território, os quais poderiam ser usados como ferramentas da USF para promoção da convivência comunitária, objetivando o fortalecimento do tecido social por meio do apoio informal, ou seja, aquele baseado na informalidade e similaridade de experiências, fornecido por pessoas do cotidiano, não treinadas para tal, como vizinhos, parceiros, entre outros (J. Souza et al. 2013).

Quanto à perspectiva da usuária, Amanda foi categórica ao afirmar que não tem interesse por se aproximar de outros lugares do bairro ou da cidade por meio dos quais pudesse estabelecer novos vínculos e/ou desenvolver outras atividades. Amanda restringe sua resposta a yoga, cuja prática fora indicada pelo médico da USF. Fica evidente o lugar de saber atribuído ao médico e a importância dada às suas indicações, uma vez que a usuária demonstra ter considerado a proposição do profissional, dando indícios de que experimentaria tal prática caso houvesse condições. E, assim, diante de tal situação, alguns aspectos podem ser questionados visando à reflexão: O médico, ao indicar que a usuária praticasse yoga, tinha conhecimento da condição socioeconômica da usuária e da ausência da oferta de aulas gratuitas? Foram pensadas formas de a usuária ter acesso à prática de yoga? Existe espaço na relação entre profissional e paciente para negociar tal indicação? Quais benefícios eram esperados da prática de yoga? Além da yoga, quais outras atividades poderiam ser de ajuda para a usuária? O território, por meio de escolas, Organizações Não Governamentais (ONG’s), cooperativas, oferecem práticas que promovem benefícios similares? Considera-se que tais questionamentos oportunizam o estabelecimento de relações mais simétricas entre profissionais e usuários e, consequentemente, a proposição de estratégias mais conectadas aos recursos do território e ao contexto dos moradores. 


\subsection{O contato com o sofrimento mental e o preparo para o trabalho: caminhos para a transformação das práticas}

Esta categoria aborda as experiências (profissionais e de formação) de contato com o sofrimento mental e as decorrentes transformações das práticas. Os relatos selecionados para ilustrar essa categoria tratam, portanto, do aprendizado através do contato com o sofrimento mental e de (novas) práticas de preparo do profissional para o enfrentamento da demanda por cuidados em saúde mental.

"A minha formação... de prática nós não tivemos nada de saúde mental. Foi uma Psiquiatria dura, entendeu? Intervencionista, essa Psiquiatria tradicional, que taxa, que estigmatiza. É bem desse jeito mesmo, né? O que eu acho que ainda é. Talvez os serviços tenham ajudado a tirar um pouco do que a gente ensina, do que a gente aprende na faculdade. Mas na minha época a gente não tinha possibilidade de ir pra serviços de saúde, né, era dentro da universidade e só. [...] Bom, acho que foi, assim, uma possibilidade (sobre trabalhar em hospital psiquiátrico) muito rica de entrar nesse universo, né, da loucura, e de me envolver plenamente. Então, eu acho que, mais do que o papel de clínico, eu tinha o papel mesmo de... E fui entendendo por que é que algumas pessoas de outras áreas se envolviam tanto, porque é impossível não se apaixonar pela saúde mental. A necessidade de afeto daquelas pessoas... a necessidade de conversar..."

(Miguel, Médico/Coordenador)

"Eu tenho (dificuldade no contato com o sofrimento mental). Tenho um pouco. Saúde mental não é muito a minha área, não. [...] Eu fiz 3 meses de estágio no (fala o nome de um hospital psiquiátrico de internação total) e lá a gente passou por todas as áreas, né? Desde o agudo até os mais tranquilos, que moram lá dentro, né, tem pacientes que moram lá. E eu não me identifiquei. Ainda na época, eu lembrei... Eu lembro até hoje que, na época uma professora minha ela dizia que a Psiquiatria ou você ama ou você odeia. E eu não me identifiquei de forma alguma com a Psiquiatria. Então, assim, eu não tenho, eu, particularmente, não tenho preparo pra lidar com o paciente de saúde mental. Muitas vezes eu não sei como lidar com ele, eu não sei o que fazer, muitas vezes eu não sei nem o que dizer. Eu me sinto um tanto acuada com eles."

(Marina, Auxiliar de Enfermagem)

"Na escola, né, que eu fazia o curso na época... as professoras deram toda a orientação de como você se comportar, né, exatamente, que você tem que vê-los como doentes que são, não é o doente da... do andar lá que é da patologia clínica, mas não deixa de ser doentes, né? E a orientação é muito rígida, inclusive a fiscalização porque lá eles têm uma tendência a querer fugir. Então eles falam 'Vocês ficam atentas porque uma brechinha que eles veem, eles fogem mesmo!' Né? E não criar 
conflitos, né, separar conflito se houver, assim, mesmo ali se não tem medicação, é tudo medicação oral, a maioria, e conferir se realmente tomaram porque eles são muito espertos, eles escondem, né? Então, a gente teve esse preparo... E lá tinha pessoas lá de todas as idades. Tinha uma jovem, uma menina, uma pré-adolescente, tinha senhoras já de idade, né? E é muito estranho ver isso."

(Helena, Auxiliar de Enfermagem)

"Porque mesmo lá no (fala o nome de um hospital particular), quando chegava um paciente lá pra gente que tinha esse transtorno, ficava lá, era medicado com calmante e de lá era encaminhado, ou pro (fala o nome de um serviço psiquiátrico de internação total) [...] ou então, pro (fala o nome de um hospital psiquiátrico de internação total) Aí, eles davam esse choque como se fosse uma medicação pra poder deixar os pacientes calmos. Quer dizer, relaxava as musculaturas lá... 'Quantas voltagens? Tchuff!' [...] Eu ficava horrorizada. Falava 'meu deus do céu!'[...] Ai, (os estágios ajudaram) bastante. Apesar de que como agente comunitária, eu não posso atuar, assim, porque tem uma burocracia, por exemplo, eu sou agente comunitária, eu não posso trabalhar como técnica de enfermagem. [...] Assim, me ajudou muito e ajudou, também, a ta orientando as pessoas. Porque, às vezes, você bate o olho numa pessoa, você sabe 'aquela pessoa ali, assim, assim, assim'. [...] Aí, eu tenho que me conter e segurar. Porque você passa a ter vários conhecimentos, então você passa a ter mais facilidade de identificar a maneira da pessoa olhar, a maneira da pessoa conversar, a maneira da pessoa vestir. Ah, muda tudo. É totalmente diferente".

(Neide, ACS)

“E tem a educação continuada também. [...] Que aí, assim, a equipe vê que demanda que ta tendo de cada profissão e a gente dá tipo uma aulinha sobre isso. Eu já fiz duas, uma sobre depressão, transtorno de humor, né, e outra sobre desenvolvimento infantil que, daí, foi até legal que a gente fez junto, fez eu, a T.O., a Fisio e a Fono. [...] Na verdade é assim, cada um tem um dia pra falar... Aí, coloca um dia lá, é de quarta de manhã, né, então, vai escreve lá 'dia tal vai ser os agentes, dia tal o médico'. Aí, na semana você pergunta 'E aí, gente, qual que é a demanda?'. Às vezes não tem demanda e você tem que tirar da... do nada, assim. E... e é isso.”

(Ana Paula, Residente de Psicologia)

“E, assim, tentativas que a gente fez na época de oferecer cursos para os profissionais das unidades básicas de saúde e do pronto atendimento para eles poderem ter uma capacitação, pra atender quadro leves a moderados, né, por exemplo, de transtorno mental como ansiedade, depressão, poderem dar um suporte para quando as pessoas tiverem um sofrimento psicológico significativo, mesmo se não fosse um transtorno mental... [...]. Todas as nossas tentativas falharam totalmente. Então, cursos que a gente dava, a gente observava que não dava nenhum impacto em como os profissionais e as equipes lidavam com a saúde mental. Tentativas também de estabelecer modelos de guia de encaminhamento, que de certa maneira obrigasse as pessoas a colocar claramente o que elas esperavam que o serviço especializado fizesse... também não funcionaram nada."

(Mário, Psiquiatra) 
Em seus relatos, Miguel, Marina, Helena e Neide descrevem e significam experiências anteriores de contato com o sofrimento mental, seja durante a prática profissional ou durante a formação. Miguel, ao falar sobre sua experiência de trabalho em um hospital psiquiátrico, referiu que, em razão de sua formação dura, intervencionista, tradicional, "que taxa $e$ estigmatiza” [sic], ele teve receio do contato com o sofrimento mental mas, a partir do convívio com os pacientes do hospital, aproximou-se dessas pessoas, deparando-se com a fragilidade e com a necessidade de afeto das mesmas, o que o levou à conclusão "Não tem como não se apaixonar” [sic]. Já Marina deu indícios de que se mantém menos aberta para o contato, encontrando respaldo na fala de uma professora que afirmou que "Psiquiatria ou você ama ou você odeia” [sic]. Ela então atribui à “falta de identificação” o motivo para não se aproximar e não se implicar com o sofrimento mental. Miguel e Marina, apesar de significarem de maneiras diferentes a experiência de contato com o sofrimento mental, compartilham da mesma ideia de que é preciso identificar-se com a questão para implicar-se com ela.

Amarante (2009), utilizando-se dos conceitos de Franco e Franca Basaglia, pontua: “A Psiquiatria colocou o sujeito entre parênteses para ocupar-se da doença; para Basaglia a doença é que deveria ser colocada entre parênteses para que pudéssemos ocupar-nos do sujeito em sua experiência” (p. 5). A partir dessa reflexão, pode-se inferir que Miguel, em sua experiência, suspendeu a doença (o conceito, o rótulo) e se permitiu estar em contato com outras pessoas, também em suas experiências. O que não significa a negação da existência da dor ou do sofrimento mas sim, a compreensão da existência global e complexa de qualquer pessoa.

Marina, Neide e Helena relatam as experiências que tiveram durante o Curso Técnico de Enfermagem, por meio do qual realizaram estágios em serviços especializados em saúde mental. Infere-se, por meio da reprodução de falas de professores que tiveram, que os cursos, de certa maneira, atuam de modo a reforçar a lógica de que a pessoa em sofrimento mental precisa ser vigiada por ser perigosa, inconstante e difícil de ser controlada. Observa-se que o preparo proporcionado por tais experiências acaba por justificar e naturalizar a lógica do isolamento e da estranheza do sofrimento mental. Tais práticas reforçam a crença de que a pessoa em sofrimento mental é perigosa, agressiva, instável e manipuladora, de forma que as entrevistadas afirmam: "Eu me sinto um tanto acuada com eles" [sic], "é muito estranho ver isso" [sic] e "a maneira da pessoa olhar, a maneira da pessoa conversar, a maneira da pessoa vestir [...] é totalmente diferente” [sic].

Supõe-se, por meio dos relatos, que a postura pautada na crença da periculosidade da loucura dificulta que o usuário seja olhado para além da doença, em sua complexa e múltipla 
existência. A loucura é tida, nesta perspectiva, como algo que não se domina, incompreensível, que não tem cura. As entrevistadas parecem possuir uma compreensão parcial do sofrimento mental, como se apenas o "louco" estivesse sujeito a acessos de raiva, a períodos de tristeza intensa e a criação de conflitos. O sofrimento que assola o outro é tido como diferente do próprio sofrimento. Assim, torna-se difícil o exercício de colocar-se no lugar do outro ou de ver o próprio sofrimento representado no sofrimento do outro. Neste sentido, Dimenstein (2004) aponta que o principal desafio da Reforma Psiquiátrica consiste em desmistificar a loucura e denunciar concepções naturalistas que, historicamente, justificam o asilamento, a medicalização e a sua patologização.

O relato de Ana Paula acerca da Educação Continuada foi selecionado para ilustrar as práticas de preparo do profissional para o enfrentamento da demanda por cuidados em saúde mental na ESF. De acordo com o Ministério da Saúde (2012b), trata-se de uma estratégia de qualificação das práticas de cuidado, gestão e participação popular. Ressalta-se, portanto, que não se trata de uma estratégia específica de preparo para o cuidado em saúde mental mas que muito tem a contribuir para este cuidado, na medida em que é compreendida como uma ferramenta de trabalho em equipe, que preza pela troca de saberes e pela construção de estratégias contextualizadas que promovam o diálogo entre as políticas gerais e a singularidade dos lugares e das pessoas. Assim, observa-se o investimento em estratégias mais dialógicas, implicadas em promover a criatividade e a autonomia dos atores (trabalhadores, gestores e usuários) envolvidos no processo de fazer saúde, visando transformações do funcionamento dos serviços. Dessa forma, conclui-se que a Educação Continuada constitui uma importante ferramenta para a consolidação do cuidado no território, preconizado pela Política Nacional de Atenção Básica e pela Reforma Psiquiátrica.

Entretanto, o relato de Ana Paula traz elementos que evidenciam a forma como esta atividade é colocada em prática no cotidiano do serviço. Segundo ela, há uma sequência prédeterminada pela equipe que indica qual profissional deve coordenar a Educação Continuada em cada semana. E, a cada reunião, a partir da demanda da unidade, estabelece-se o tema a ser abordado na próxima semana. De acordo com a residente, eventualmente acontece da equipe não conseguir eleger um tema a ser discutido na semana seguinte, o que leva o profissional que coordenará a atividade a "tirar do nada” [sic] um assunto para discussão. Percebe-se através do relato que apesar da proposta da Educação Continuada ser bastante ampla e dinâmica, na prática esta estratégia parecer ser executada de forma burocrática e rígida. A própria residente ao se referir à atividade como “aulinha” [sic] parece reduzir a proposta da 
mesma à mera exposição de temas, destituindo o potencial deste espaço como fomentador de reflexão, avaliação e construção de práticas.

A Política Nacional de Atenção Básica (Ministério da Saúde, 2012b) destaca que "é importante sintonizar e mediar as ofertas de Educação Continuada pré-formatadas (cursos, por exemplo) com o momento e contexto das equipes, para que façam mais sentido e tenham, por isso, maior valor de uso e efetividade” (p. 40). Assim, voltando ao relato, dada a dificuldade em sintonizar o espaço da Educação Continuada com o contexto em que a equipe está inserida, a atividade perde o sentido para os profissionais, que acabam tomando como tarefa, obrigação, chegando ao ponto da equipe que se diz sobrecarregada pelo excesso de demanda ter dificuldades para eleger um tema para discussão.

Mário, o psiquiatra responsável pela supervisão dos casos de saúde mental das duas USFs em questão, relata duas estratégias que foram experimentadas visando à capacitação dos profissionais da Atenção Primária para realizar atendimento de casos leves e moderados, evitando o encaminhamento para o serviço especializado. Segundo ele, os cursos "falharam totalmente" [sic] e a estratégia de guias de encaminhamento "também não funcionaram nada" [sic]. Neste sentido, pode-se pensar que ambas consistem em práticas que foram apresentadas aos profissionais como um modelo pronto a ser seguido. Tanto os cursos quanto as guias consistem em medidas que "vêm de fora”, não tendo sido elaboradas conjuntamente com os profissionais da Atenção Primária, a partir das próprias demandas e necessidades. Quando se refere às guias, o psiquiatra acrescenta, ainda, que se tratava de uma estratégia que "obrigasse as pessoas a colocar claramente o que elas esperavam que o serviço especializado fizesse” [sic]. Infere-se que os profissionais da Atenção Primária ao encaminharem a pessoa em sofrimento mental para um serviço especializado, visavam compartilhar a responsabilidade por uma tarefa que não estavam dando conta no contexto da rede básica. Portanto, parece despropositado solicitar que fossem capazes de descrever claramente o que esperam do serviço especializado. Questiona-se, então, de que maneira essa prática ajudaria na preparação dos profissionais da Atenção Primária para o contato com o sofrimento mental.

Observa-se que as USFs se preocupam em desenvolver estratégias mais dialógicas, tentando colocar as pessoas em relação, pautadas na conversa, na discussão em equipe e na troca de saberes. Entretanto, infere-se que tais estratégias ainda são tomadas como tarefas, compromissos ou obrigações, ficando maçantes, ou mesmo esvaziadas de sentido. Nota-se, a partir das entrevistas, que o treinamento para o enfrentamento do sofrimento mental ainda é principalmente centrado nos procedimentos de identificação e medicalização do sofrimento. Apesar de, em alguns momentos, serem experimentadas estratégias mais dialógicas, estas 
ainda são tímidas e acabam perdendo o sentido num contexto em que o cuidado é centrado na terapêutica. Parece faltar espaço para uma reflexão mais aprofundada sobre as práticas, em que se coloque em questão a razão e o formato das mesmas. Nesse sentido, considerando o contexto das Unidades de Saúde da Família, parece mais pertinente que os profissionais sejam capacitados para lidar com a adversidade e para usar a criatividade, dispondo dos recursos do território e lançando mão de estratégias psicossociais.

\subsection{Dificuldades encontradas no processo de cuidado da saúde mental}

Esta subcategoria aborda as dificuldades apontadas pelos entrevistados quanto ao processo de cuidar da saúde mental.

\subsubsection{Falta de suporte psicológico}

Os profissionais destacaram a necessidade de maior suporte psicológico para o enfrentamento do sofrimento mental.

"A gente sempre cobrou desde o comecinho do Núcleo, quando a gente começou a sair pra rua e fazer visita e vinha essas demandas, a gente sempre cobrou que a gente precisava de ter um suporte, tanto pra nós, quanto pra gente poder, também, ajudar. O nosso suporte é assim, a gente chega da rua, dependendo do caso, a gente desabafa uma com a outra. E traz na discussão de família aquele caso, então, todo mundo discute, vê o que cada um pode estar ajudando."

(Tânia, ACS)

"O que a gente precisa é de um suporte, que eu falo assim, pra gente, pra nós, mesmo, assim, não de como lidar, né, como... Mas, pra gente jogar pra fora aquilo que a gente escuta também, né, tudo que a gente vê. A gente vê violência, marido que bate na mulher, o que que a gente faz? A gente [...] que sabe que existe, o que a gente pode fazer? Fazer a notificação. A notificação não é queixa. A queixa tem que partir da mulher. A gente orienta 'Vai na delegacia da mulher, tal'. Mas isso é com ela, né?" 
Ao longo da realização das entrevistas, alguns profissionais, notadamente os agentes comunitários de saúde, explicitaram a necessidade de um suporte psicológico que contribuísse para o enfrentamento das demandas de saúde mental. Tânia, a agente comunitária mais antiga da USF, relata que os agentes, desde a implementação do serviço, sempre sentiram falta de um espaço para dividirem as dúvidas e angústias decorrentes do contato com o sofrimento mental. Refere que os únicos recursos dos quais dispõem é desabafar uns com os outros ou levar o caso em reunião de equipe, na tentativa de buscar alívio da angústia e da sobrecarga emocional através da partilha com os colegas. O relato de Lúcia corrobora com o de Tânia quando faz referência à falta de um espaço para "jogar pra fora aquilo que a gente escuta, [...] tudo que a gente vê" [sic].

Para Waidman, Costa e Paiano (2012), os agentes comunitários, por compartilharem do mesmo contexto social e por conhecerem de perto a dinâmica da comunidade, são entendidos como mediadores da relação entre o serviço de saúde e o usuário, estabelecendo uma comunicação interpessoal e afetiva com a população. A atuação destes profissionais está atrelada a uma concepção ampliada de saúde, incluindo determinantes biopsicossociais através de um olhar para toda a família e não apenas sobre o indivíduo (Pupin-Andrade, 2013; Ministério da Saúde, 2012b). Nesse sentido, considerando os pressupostos da Reforma Psiquiátrica e a ênfase no cuidado de base territorial, os agentes comunitários detêm grande papel na identificação e acompanhamento dos casos, tornando-se, assim, importantes facilitadores do cuidado em saúde mental.

Devido à função que desempenham, os agentes comunitários estabelecem um contato muito próximo com os moradores e as famílias, conhecendo, em alguns casos, a dinâmica familiar e a casa em seus ambientes mais íntimos. Nesse sentido, o intenso envolvimento com as famílias e seu sofrimento pode acarretar uma sobrecarga emocional e constituir um fator ansiogênico para esses profissionais. Assim, acredita-se que seria de muita ajuda a criação de espaços para reflexão e discussão sobre as múltiplas nuances que compõem a existência humana. A possibilidade de problematização das questões relativas ao humano poderia contribuir para uma compreensão mais ampla da pessoa em sofrimento, da morte, da loucura e do lugar das práticas de saúde dentro do processo de vida. Nesse sentido, tal proposta não se pauta em aulas ou cursos, mas em espaços cotidianos de aproximação com as questões relativas ao contato com o outro. O que é o sofrimento? Em que medida o sofrimento do outro representa o meu sofrimento? Quais sentidos têm a morte? Quais concepções de loucura perpassam as práticas? Como eu olho para o outro que é diferente de mim? Acredita-se que 
tais reflexões sejam de muita ajuda para o fortalecimento do profissional enquanto pessoa em relação, podendo desenvolver ferramentas que corroborem com os processos de cuidado.

\subsubsection{Insuficiência de preparo técnico}

Os relatos abaixo representam trechos das entrevistas em que os profissionais apontaram a necessidade de maior preparo técnico.

“Eu falo que a gente não ta... a gente não tem... a gente não ta preparado, não tem nenhuma estrutura... porque... é o caso... O que eu posso fazer? É trazer pra equipe. Porque eu vou falar o quê? Vou fazer o quê? Não posso. Então, eu acho assim, que a gente não tem preparo algum, não. [...] Eu não posso nem tentar porque se eu tentar alguma coisa, eu vou fazer besteira, você entendeu? Eu não sei. Eu não sei. Eu não sou preparada pra isso. Eu não sou psicóloga, eu não sou psiquiatra, entendeu?”

(Fátima, ACS)

"Eu acho difícil. Eu acho... Sempre falo assim. Nossa, as pessoas, às vezes, vêm, elas querem uma resposta, né? Paciente quer uma resposta. Parece que ele te conta alguma coisa, esperando uma solução, né? E você não tem a solução muitas vezes, né? Então, eu acho difícil. Por isso que a gente tem dificuldade, assim, mais por não saber lidar."

(Fernanda, Enfermeira)

“[...] mas, assim, eu sinto necessidade de uma capacitação realmente voltada pra atuação psicossocial, assim, porque não resolve, por exemplo, pra mim, como enfermeira, ter uma capacitação voltada a sinais e sintomas de uma determinada patologia e seu o tratamento. Isso é atuação médica, né?”

(Gabriela, Enfermeira)

Ao longo das entrevistas, muitos profissionais relataram que sentem falta de preparo técnico para o enfrentamento do sofrimento mental. Dentre os trechos selecionados para ilustrar essa subcategoria está o de Fátima, agente comunitária, que afirma enfaticamente que não tem, ou não sabe, o que fazer diante dos casos de sofrimento mental. Por se considerar completamente desprovida de ferramentas para o enfrentamento dessa demanda, Fátima opta por repassar responsabilidade sobre tais casos para os especialistas, ou seja, psicólogos e psiquiatras. Seu trabalho, portanto, fica restrito a identificar e reportar para a equipe as 
situações que demandam cuidados em saúde mental. Complementarmente, Fernanda acrescenta que é difícil lidar com essa demanda porque, muitas vezes, o "paciente quer uma resposta, [...] espera uma solução" [sic]. Observa-se que dado o modelo tecnoassistencial hegemônico, o profissional de saúde é cobrado, por si e pelos usuários, a apresentar as soluções necessárias diante das situações adversas que lhe são apresentadas. Fernanda revela ter dificuldade para atender a tais cobranças, pois, muitas vezes, também não tem as respostas. Infere-se que a possibilidade do profissional se sentir suficientemente livre para compartilhar o “não saber” com o usuário (indivíduo ou coletivo) é de grande potência, pois viabiliza uma parceria em que cada parte envolvida contribui com os seus conhecimentos e expectativas, construindo possibilidades de caminhos a serem trilhados.

Ao constatar a lacuna existente na Atenção Primária quanto ao cuidado da saúde mental, Gabriela aponta para a necessidade de uma capacitação voltada para a atuação psicossocial, que enfatize primordialmente os determinantes psicológicos e sociais, uma vez que não se vê com condições para atuar sobre tais demandas. Camargo-Borges (2007) ressalta que por terem uma "formação eminentemente tecnicista, os trabalhadores da saúde se sentem despreparados para uma intervenção mais informal e interativa” (p. 156). Para Campos et al. (2011) e Camargo-Borges (2007), as mudanças nas formas de cuidado, visando o estabelecimento de alternativas mais dialógicas e mais espontâneas, podem gerar imensa angústia no profissional, impulsionando certos procedimentos mecanizados de queixaconduta, uma vez que está acostumado a ter o domínio da situação através de técnicas, diagnósticos e protocolos.

Quinderé et al. (2013), legitimando o desafio inerente ao desenvolvimento e experimentação de novas práticas em saúde mental, sugerem algumas razões que podem dificultar este processo: o desconhecimento dos profissionais sobre o processo de Reforma Psiquiátrica; o fato dos profissionais não se sentirem ou, de fato, não serem capacitados para atuarem nos casos de sofrimento mental, ainda que leves; falta de medicações psiquiátricas para fornecer aos usuários nesse nível de atenção; a insuficiência ou mesmo inexistência de uma rede assistencial em saúde mental de suporte; além de eventuais condições precárias de trabalho e de atendimento.

Figueiredo e Campos (2009), em seu trabalho sobre o cuidado em saúde mental na rede básica de Campinas-SP, referem que, de acordo com a perspectiva dos profissionais da saúde mental, os profissionais das equipes da Atenção Primária costumam evitar o contato com o sofrimento mental devido a insegurança gerada pela falta de formação específica e a dificuldade em intervir sem a segurança dos procedimentos e da conduta medicamentosa. Já 
os profissionais da rede básica consideram sua formação inadequada para compreender e lidar com a subjetividade e o sofrimento mental mas afirmam que identificam um aumento da resolutividade quando ampliam seu campo de intervenção para além dos aspectos biológicos.

Para Quinderé et al. (2013), o fato dos profissionais da Atenção Primária não se sentirem capacitados e seguros para a condução dos casos de saúde mental repercute diretamente na relação entre oferta de serviços e impacto desta na capacidade de utilização da população. Segundo os autores, a cobrança por dar uma resposta à demanda compromete a intervenção inicial do caso por parte da equipe da Atenção Primária e, além disso, frequentemente gera encaminhamentos desnecessários aos serviços especializados, os quais, sobrecarregados, têm dificuldades para atender a demanda e, assim, promovem uma assistência pouco integral e resolutiva. Diante da contribuição de tais autores e em vista das vinhetas apresentadas, infere-se que a angústia gerada pelo contato com o sofrimento mental, bem como a dificuldade em desempenhar práticas mais dialógicas e menos ancoradas em procedimentos, contribuem para a constituição deste cenário de dificuldades da equipe para lidar com o sofrimento mental, de muitos encaminhamentos para os serviços especializados e de poucas atividades voltadas a comunidade que envolvam a intersetorialidade e a promoção da saúde mental.

\subsubsection{Dificuldade de organização dos processos de trabalho}

Durante as entrevistas, os profissionais relataram algumas situações vivenciadas no cotidiano do serviço, por exemplo, o excesso de demanda, a falta de tempo e as falhas de compreensão das propostas da ESF, como barreiras na organização dos processos de trabalho, comprometendo o planejamento e o desenvolvimento de estratégias pautadas na promoção de saúde, voltadas à coletividade.

"Mas é o que eu te falei, parece que a partir do momento que você sai de lá (casa do usuário), tudo, tudo o que você falou, tudo que você conversou, as coisas, as propostas que você fez, param ali. A impressão que dá é que você tem que pegar na mão dessas pessoas. Eu gostaria de fazer, de poder fazer, mas a gente não pode também, não tem nem como, né, Mara, fazer esse tipo de trabalho. 'Não, amanhã nós vamos fazer caminhada junto' ou 'Amanhã tem uma reunião na igreja' ou 'A senhora 
é espírita? Nós vamos amanhã no centro espírita' ou 'A senhora é evangélica, vamos no culto"”.

(Geraldo, ACS)

"A pessoa quer conversar, a gente conversa, às vezes é uma visita que demanda mais tempo. Dependendo da visita que é, da casa que é, do jeito que a pessoa tá, a gente fica a manhã toda só naquela casa, não consegue sair para fazer outra. Tem pessoas que falam pra você 'ah, não vai embora, não, fica mais um pouquinho, né, eu não tenho ninguém pra conversar', então, você fica ali. Ao mesmo tempo em que você ta pensando 'tenho que fazer um número ' $x$ ' de visitas por manhã', também não tem como virar as costas, ir embora e fazer de conta que a pessoa não ta precisando de conversar."

(Tânia, ACS)

"A única coisa que eu acho é que a gente aqui fica muito atrás de números. A gente tem metas. E aí, o número de famílias que a gente precisava trabalhar um pouco mais, mais junto, não dá, porque você tem que ir atrás de números. [...] Você tem uma meta pra cumprir. A gente sabe que a gente não tem perna. Eu acho que fazer a promoção e a prevenção, não dá pra cumprir com os números, com as metas. Acho que tinha que ter um pouco mais de tempo.”

(Catarina, ACS)

"Apesar de a gente ter, tentar ter a criatividade, de tentar fazer grupos, enfim, abordagens mais assim, mas é difícil, sabe, nós ficamos muito no no... infelizmente, a gente tenta fazer, estamos tentando batalhar essas coisas, né, na prevenção, na promoção, deteç̧ão, mas é complicado, acho que precisava melhorar... [...] É. Fica muito na assistência mesmo. Muito no atende, vem. Acho que a gente consegue até fazer bem feito isso, né, mas acho que é pouco, acho que é um serviço de Medicina de Família, eu acho que também tinha que ta voltado mais pra isso mesmo, prevenção $e$ promoção... [...] Olha, eu acho assim, mais tempo na grade dos profissionais, porque pensar a gente até pensa. Às vezes até fazemos algumas atividades na escola, com álcool e drogas. Às vezes até vem pessoal de fora, ajudar, assim, graduandos de Medicina. E a equipe nossa, mínima, auxilia, ajuda, vai, ajuda, né, organiza, mas eu acho que a gente precisava de um pouquinho mais de fôlego, eu acho (risos) que a equipe precisa pra fazer isso, ter tempo pra pensar..."

(Maurício, Médico de Família)

"Nós temos uma demanda muito grande, então às vezes, nós mesmos, auxiliares, a gente quase não participa de nenhum grupo, né, a gente fica mais na assistência e isso é um pouco meio frustrante porque, às vezes você se programa para participar de determinado grupo, mas só que a demanda às vezes é tão grande que é impossível pra uma só ficar sozinha. [...] É medicação, acolhimento, várias coisas, pós e pré consultas, exames, são várias burocracias que na maioria das vezes as duas (auxiliares de enfermagem) precisam estar lá."

(Andreia, Auxiliar de Enfermagem)

"Aí você vai explicar pra que que serve o nosso trabalho e eles falam 'ah, pra isso? Mas pra que que tem essa porcaria aqui?’. Eles não querem entender que é para 
prevenir a doença. Eles querem atendimento para a hora que eles não estão bem. 'To passando mal, vou lá, você me atende, eu tomo o remédio e acabou!' Eles não querem todo esse acompanhamento familiar, essa prevenção que o programa oferece para eles. Não adianta, a população não quer isso. Eles são imediatistas. Não quer. Entendeu?"

(Fátima, ACS)

\begin{abstract}
“Agora, esses pacientes, eles vêm pra supervisão de Psiquiatria, porém, no surto ele vem aqui. Então, às vezes, a gente fala que o desgaste causado por esses transtornos mais graves estarem aqui é muito grande pra gente, porque nós somos duas auxiliares, uma enfermeira. Então, assim, um só paciente desses segura o enfermeiro $e$ as duas auxiliares a manhã inteira pra conseguir uma regulação, pra convencer ele de que ele tem que ir pro CAPS. Então, eu, na minha avaliação, isso não é cabível. Ele tem que estar num local com profissionais capacitados. [...] Ele teria que ter acesso direto à saúde mental porque ele ta num surto mental. Não é uma questão clínica, não é uma questão urinária, não é uma dor de cabeça."
\end{abstract}

(Cínthia, Auxiliar de Enfermagem)

“É essa lógica que também é perversa, que é ruim pro nosso trabalho, que vai na contra mão do que a gente quer fazer! Trabalhar na perspectiva da saúde como um todo, da saúde mental das pessoas. Isso ainda é um impedimento pra Atenção Básica, porque nós somos avaliados pela quantidade de consultas, no final das contas, que nós produzimos. Agora, se elas são boas, ou se elas são ruins, ou se elas estão resolvendo os problemas, as necessidades, o sofrimento, a dor das pessoas, isso não é avaliado, né?"

(Miguel, Médico/Coordenador)

Como se observa nos relatos acima, alguns profissionais indicaram dificuldades em superar as estratégias já conhecidas, lançando-se a novas experiências, por assumir a priori que estas são impossíveis ou inviáveis. Geraldo, em seu relato, indica que sua atuação pode ser diferente, de forma a explorar mais possibilidades além da visita, da escuta ou da orientação. Nota-se que o agente reconhece as necessidades do usuário e é capaz de refletir sobre estratégias que poderiam responder a elas. Por exemplo, ao deparar-se com uma pessoa que mora sozinha e apresenta queixas de tristeza e solidão, uma possibilidade de atuação do agente seria acompanhá-la nos primeiros momentos de determinada atividade de seu interesse, até que ela fosse capaz de desempenhá-la por si só ou acompanhada por outro membro da família ou da comunidade. No entanto, observa-se que esta possibilidade de atuação é interditada antes mesmo de ser considerada uma proposta real. Toma-se por certo que o agente não tem tempo hábil para desempenhar um acompanhamento tão intensivo de pessoas da população, entretanto não se verifica quantas são as pessoas com essa necessidade, por quanto tempo seria necessário esse acompanhamento ou quais as consequências futuras 
para a USF decorrentes da forma como o caso evolui. Assim, o agente abdica da proposta, tomando-a por impossível, ou inviável, antes mesmo de compreender o seu impacto e de explorar maneiras de viabilizá-la. Por fim, se reproduzem as práticas já conhecidas e a sensação de impotência.

A falta de tempo devido ao excesso de demanda é uma das dificuldades apontadas pelos profissionais como sendo um dos entraves que atravessam os processos de trabalho. $\mathrm{O}$ relato de Andreia é ilustrativo da queixa de alguns profissionais sobre o excesso de demanda e consequente falta de tempo para realização das tarefas. Para Andreia, o dia-a-dia atribulado, atravessado pelo excesso de tarefas programadas e pela necessidade de atenção a usuários que recorrem ao serviço sem horário agendado, impede que ela se envolva com outras atividades, como grupos, deixando, segundo a mesma, o cotidiano esvaziado de sentido, maçante e "um pouco meio frustrante" [sic]. Maurício aponta que a atuação da equipe fixa "fica muito na assistência” [sic], ou seja, voltada para ações mais pontuais e pautadas nas demandas imediatas apresentadas pelos usuários. Destaca-se que o médico compreende que a atuação da Medicina de Família deve abranger ações de "prevenção, promoção e detecção" [sic], entretanto, de acordo com sua perspectiva, a equipe encontra-se em situação de tamanha sobrecarga que compromete o desenvolvimento de estratégias que extrapolem a doença e considerem tanto a pessoa quanto a comunidade, num processo contínuo de busca por melhores condições de vida.

No mesmo sentido, Tânia e Catarina, ambas agentes comunitárias, apontam que a exigência por cumprirem um determinado número de visitas acaba por impedir que se dediquem mais integralmente àquelas pessoas mais necessitadas de um encontro, de uma conversa. De acordo com Catarina, é inviável conciliar os números, as metas, com as atividades de promoção e prevenção. A partir da observação participante e da realização das entrevistas, foi possível notar que a equipe que Catarina e Tânia integram mantém um ritmo acelerado de trabalho, evidenciando cansaço e estafa. Questionam-se os pormenores dos processos de trabalho que impedem que os profissionais consigam dividir seu tempo de forma satisfatória. Infere-se que a impressão de falta de tempo esteja atrelada a uma determinada lógica de organização das tarefas, pautada na crença de que qualquer quantidade de tempo seria insuficiente para atender a tantas demandas. Entretanto, conforme há a oportunidade de nos atentarmos para a finitude do tempo, podemos adotar uma postura de maior protagonismo e atenção frente às ações cotidianas, preenchendo-as de possibilidades.

Outro entrave dos processos de trabalho apontado pelos profissionais é a dificuldade de compreensão da proposta da ESF, tanto pela população quanto pelos profissionais e 
gestores. Fátima relata que alguns usuários têm dificuldade em compreender a proposta da ESF quanto à realização de intervenções de promoção e prevenção. Segundo ela, a população é “imediatista” [sic], entendendo que é mais interessante dispor de um serviço que intervém no alívio da dor, do que um serviço que aja preventivamente, desenvolvendo ações que evitem o aparecimento do desconforto.

Já Cínthia, frente às dificuldades para o manejo da situação de crise, aponta uma solução que revela uma compreensão equivocada quanto ao percurso do usuário em sofrimento mental através dos diferentes níveis de atenção que compõem o sistema de saúde. Para ela, o paciente em sofrimento mental "teria que ter acesso direto à saúde mental” [sic], sem a necessidade de passar pela Atenção Primária, numa perspectiva de separação corpomente. Para Lancetti (2001), as pessoas não padecem de sofrimento mental e físico separadamente. Segundo o autor, as condições ambientais, sociais e mentais constituem esferas inter-relacionadas e é através de mudanças nessas esferas que é possível alcançar os impactos desejados pelas políticas de saúde mental. Assim, dado o contexto da Reforma Psiquiátrica e, também, considerando que é no território onde se manifestam as crises psicóticas, as experiências diversas de sofrimento, as situações de violência, abuso sexual e dependência abjeta, parece pertinente que os processos de produção de saúde sejam gerados, ao menos em parte, no território, ou seja, no âmbito "das famílias, da comunidade, dos universos existenciais das pessoas e do diálogo com seus interlocutores invisíveis” (Lancetti, 2001, p. 117). Quinderé, et al. (2013) apontam que o desinteresse por parte de alguns profissionais da Atenção Primária em abordar os casos de saúde mental, assim como a desarticulação da rede básica com os demais níveis de assistência, podem acarretar a descontinuidade ou mesmo a ausência de assistência da pessoa em sofrimento mental. Assim, a proposta de Cínthia de que o usuário em sofrimento mental recorra diretamente ao serviço especializado evidencia uma fragmentação da pessoa, incompatível com princípio da integralidade, tão prezado pelo SUS.

Levando em consideração a Política Nacional de Saúde Mental e os princípios e diretrizes que embasam o Sistema Único de Saúde, é previsto que o usuário seja acompanhado por uma unidade de saúde de referência da Atenção Primária e, caso haja necessidade, seja encaminhado para serviços especializados. Como consequência desse arranjo, há a possibilidade dos usuários e profissionais firmarem parcerias, a partir das quais as situações de sofrimento possam ser significadas dentro do histórico de cada pessoa. Almeja-se que tais parcerias possibilitem o desenvolvimento de estratégias mais conectadas com o cotidiano das pessoas, pensadas a partir dos conhecimentos e vivências de ambas as 
partes envolvidas, evitando encaminhamentos desnecessários ou, ainda quando necessários, possibilitando que a equipe de referência acompanhe o percurso do usuário pela rede de serviços, assistindo-o em seus caminhos.

Miguel, por sua vez, chama a atenção para o fato da avaliação dos serviços de saúde ser realizada a partir da quantidade de consultas realizadas, enfatizando a produtividade e não a efetividade das ações. Para o coordenador, essa forma de avaliar o serviço reforça uma “lógica perversa” [sic], que vai na contramão das propostas da Atenção Primária que prezam pelo estabelecimento de vínculo, pela corresponsabilização e pelo saber compartilhado (Ministério da Saúde, 2010, 2012b). Observa-se, assim, certa incompatibilidade entre o que se espera dos serviços de Atenção Primária e a forma como os mesmos são avaliados pelos gestores do sistema de saúde. Infere-se que tal entrave possa estar associado à intensificação da fragmentação dos fazeres em saúde e à mecanização das ações de cuidado, uma vez que os profissionais são mais bem avaliados quanto mais procedimentos desempenham. Nesse sentido, ressalta-se a necessidade de serem instituídas formas de avaliação da efetividade dos serviços de Atenção Primária que superem os indicadores únicos e mensuráveis de eficiência e produtividade e considerem os aspectos psicossociais das intervenções diante do território no qual o serviço está inserido. Segundo Carvalho e Amarante (1996) e Wetzel e Kantorski (2004), os programas e serviços não devem ser compreendidos como algo dado, único, verdadeiro e natural mas como processos em movimento, que atuam de acordo com uma dinâmica própria. Assim, a avaliação deve incluir o mapeamento das relações e acontecimentos que ocorrem nesses serviços, superando a definição de parâmetros de qualidade a serem alcançados.

Como iniciativa recente do Ministério da Saúde de ampliar o acesso e melhorar a qualidade da Atenção Primária, tem-se, desde 2011, o Programa Nacional de Melhoria do Acesso e da Qualidade da Atenção Básica (PMAQ). A adesão ao Programa pelos municípios tem caráter voluntário e prevê um processo contínuo de melhoramento dos padrões e indicadores de acesso e de qualidade que envolva a gestão, o processo de trabalho e os resultados alcançados pelas equipes de saúde da Atenção Primária. Dentre os objetivos específicos do PMAQ, tem-se a proposta de institucionalização de uma cultura de avaliação da Atenção Primária no SUS e de gestão com base na indução e acompanhamento de processos e resultados. Para isso, são mobilizados gestores, equipes e usuários num processo de mudança de cultura de gestão e qualificação da Atenção Primária, constituindo uma estratégia ampla e continuada de aprimoramento dos serviços, a partir de processos reflexivos 
e avaliativos que consideram as especificidades regionais e locais (Ministério da Saúde, 2012c).

Dado este contexto, ao menos no âmbito de iniciativas do Ministério da Saúde, é possível observar a ênfase atribuída ao desenvolvimento de estratégias que avaliem a efetividade da Atenção Primária, levando em conta a dinamicidade dos serviços, a singularidade dos contextos e o processo saúde/doença das pessoas. Infere-se que ainda é necessário avançar na organização dos processos de trabalho experimentando e aprimorando formas de avaliação das ações desempenhadas e, também, formas de cuidado pautadas nas estratégias de promoção e prevenção, partindo de propostas locais para que, então, estas possam fazer sentido tanto para usuários quanto para profissionais e gestores.

\subsubsection{Insuficiência e/ou desarticulação da rede}

Ao longo das entrevistas, os profissionais indicaram que a insuficiência e/ou a desarticulação da rede de equipamentos sociais é uma das dificuldades que interfere no cuidado em saúde mental ofertado.

"A gente sente falta, assim, de rede de apoio pro portador de transtorno mental... é muito descoberto. A pessoa que entra em surto, ela quer ir num P.A. (Pronto Atendimento), ela vai ficar lá, sendo sedada porque é a única forma dela ficar tranquila, até chegar uma avaliação psiquiátrica e até sair uma vaga são dias, às vezes até semanas. Ela fica lá. [...] Não tem rede de apoio.”

(Gabriela, Enfermeira)

"Eu acho que a Saúde da Família tem esse papel de fazer... estar no meio da articulação. Eu não acho que ela deva ser o articulador, não. Não é isso. Eu não sou tão tão tão, assim, não. Mas ela tem que estar no meio, entendeu? E, pelo menos, fazer o nosso papel. De atender, de acolher, de... [...]. Porque a gente trabalha muito por encaminhamento, né? Mas, aí, não funciona porque um passa o problema pro outro, e, aí, acaba voltando. Essa articulação, então, é informal. E ela começa com o problema concreto. Não existe uma articulação encima do nada, assim, entendeu? Mas com o problema concreto, você chama as pessoas. E aí, todo mundo ta sabendo daquele problema! Interessante é isso. Por exemplo, a assistência social já conhece a família. A promotoria conhece a família. O pessoal do (fala o nome do serviço de atendimento à violência doméstica e agressão sexual) conhece a família. Todo mundo conhece a família. Porque, de alguma forma, todo mundo já trabalhou com aquela família. Só que nunca se conversou, entendeu? Então, a gente chamar essa 
articulação é interessante. Porque, pelo menos, a gente 'Ó, ta difícil, né?', 'É, ta difícil', 'ta difícil', 'ta difícil', 'o que nós vamos fazer? Como que a gente pode...?'. E eu acho que, aí, a coisa começa a andar, entendeu?”

(Jorge, Médico/Coordenador)

“Agora, nós temos várias situações que os pacientes, na minha opinião, ficam subatendidos porque... [...] Porque eu acho que a saúde mental da cidade, ela funciona bem na sua... na lógica do sistema, de como ela ta montada. Então, eu acho que ela funciona bem. Mas, ela é pequena perto do tamanho do problema. Então, fica muito paciente pra trás. [...] Paciente que não ta fazendo psicoterapia, por exemplo, só ta, na verdade, tomando medicamento. Não ta tendo uma atividade extra, né? Complicado. E a prevalência dos problemas de saúde mental é grande, né? Não os problemas graves, mas os problemas em geral, parece que é uma prevalência bem alta."

(Jorge, Médico/Coordenador)

“[...] Nós não temos uma rede, ainda, integrada. A nossa estrutura é muito precária. Isso é uma coisa que é importante; a ambiência é importante, também, pra saúde mental. Você ter espaço... Então, a gente trabalha muito no improviso."

(Miguel, Médico/Coordenador)

"Isso é uma angústia dentro de mim que vai ser pra sempre. Porque assim, não tem pra onde encaminhar, aquelas questões de vagas, tudo isso. Mas, a gente encaminha."

(Carolina, Residente de Psicologia)

"Então, do ponto de vista prático é assim: a pessoa chorou na unidade, normalmente vai para o serviço de saúde mental; ela ficou brava na unidade, ela vai para o serviço de saúde mental; ela ficou ansiosa na unidade, ela vai para o serviço de saúde mental. E você não tem uma estratégia de dar suporte na assistência primária para as equipes de assistência primária poderem manejar situações de sofrimento psíquico e de transtorno mental.”

(Mário, Psiquiatra)

As falas dos profissionais são ilustrativas dos entraves decorrentes da desarticulação e/ou insuficiência da rede de apoio em saúde mental da qual dispõem os usuários.

Gabriela se vale de uma situação hipotética para evidenciar essa situação. Segundo ela, a rede é falha, pois uma pessoa em surto pode passar muitos dias em um serviço de Pronto Atendimento, sendo sedada, até que consiga uma vaga em serviço especializado. Jorge considera que a rede do município funciona bem, entretanto, “é pequena perto do tamanho do problema" [sic], deixando muitos pacientes subatendidos. O coordenador enfatiza não atribuir às USFs a responsabilidade pela articulação dos diferentes serviços. Para ele, a Saúde da 
Família deve ser parte integrante da rede de serviços que compõem o sistema de saúde, desempenhando as ações em saúde mental que lhe competem. Partindo de sua experiência prática, Jorge relata que os casos mais complexos costumam mobilizar diferentes serviços e profissionais, entretanto observa-se que, frequentemente, as intervenções são pensadas e efetuadas separadamente por cada equipamento. Nesse contexto, quando é criada a possibilidade de troca entre os diversos atores envolvidos, pode-se referendar a dificuldade da situação, unindo saberes e fazeres voltados para uma compreensão e intervenção mais amplas do caso. Observa-se que, frequentemente, o usuário é assistido por vários serviços, que adotam diferentes condutas, entretanto, considerando a proposta de articulação dos serviços e ações, parece mais interessante e resolutivo que fosse elaborado um projeto terapêutico único e integrado para cada usuário, que levasse em consideração os diferentes equipamentos sociais disponíveis em cada localidade.

Para Campos et al. (2011), o “estranhamento” entre os serviços pode ser decorrente das tensões produzidas a partir da proposta de corresponsabilização. De acordo com os autores, de um lado, as equipes da Atenção Primária delegam os cuidados em saúde mental aos especialistas, de outro, os profissionais de saúde mental pressionam para que a Atenção Primária assuma, ao menos, os casos mais leves. Como consequência, o usuário é prejudicado, uma vez que não encontra lugar para seu sofrimento na rede de cuidados.

Frateschi e Cardoso (2014) em estudo qualitativo visando investigar a avaliação dos usuários acerca dos cuidados em saúde mental recebidos pelos serviços de Atenção Primária encontraram que os usuários compartilham da percepção dos profissionais quanto à falta de articulação entre os serviços e ações de saúde. Tal estudo descreve a situação de usuários necessitados de cuidados em saúde mental percorrendo serviços de saúde sem que nenhum assuma ou se responsabilize pelo caso, caracterizando uma forma de atenção em que os encaminhamentos são pouco resolutivos. Conforme aponta Jorge acerca da ESF, por atuarem principalmente por meio de encaminhamentos, muitas vezes o paciente é redirecionado para outros serviços sem que seja firmada uma relação de corresponsabilização entre os serviços envolvidos e entre estes e o usuário. Dessa forma, tem-se uma situação em que "um passa o problema pro outro" [sic], nenhum serviço se responsabiliza pelo caso e o usuário acaba sem referência para os cuidados em saúde mental.

Para Camuri e Dimenstein (2010), trata-se da repetição da lógica do especialismo biomédico com o esquadrinhamento do sujeito e de seu sofrimento, de forma que as equipes da Atenção Primária, de modo geral, não acolhem e não se responsabilizam pela demanda, mas, encaminham o usuário para quem foi delegado o poder da "cura”. Segundo Pinto et al. 
(2012), a fragmentação das linhas de cuidado, em seus fluxos e conexões, podem resultar em itinerários terapêuticos pontuais, superficiais e desarticulados com as demandas e necessidades de saúde dos usuários.

Conforme ressalta o Ministério da Saúde (2004a) em material informativo sobre os CAPS, as redes são compostas por muitos centros e muitos nós, o que as tornam complexas e resistentes e, neste contexto, é fundamental que não se perca de vista que o eixo organizador dessas redes são as pessoas, sua existência e seu sofrimento. A partir desta perspectiva, a rede de cuidados deve ser constituída pelos "recursos afetivos (relações pessoais, familiares, amigos etc.) sanitários (serviços de saúde) sociais (moradia, trabalho, escola, esporte etc.) econômicos (dinheiro, previdência etc.) culturais, religiosos e de lazer” (p. 11), instrumentalizando as equipes de saúde para os esforços de viabilização da Reabilitação Psicossocial, visando atuar sobre a complexidade das demandas de inclusão daqueles que, historicamente, estão à margem da sociedade por não corresponderem a um dado padrão de normalidade.

Segundo Mário, as pessoas em sofrimento mental são frequentemente encaminhadas para o serviço de saúde mental sem que seja explorado o leque de ações que compete à Atenção Primária, evidenciando a necessidade das equipes deste nível de assistência estarem mais bem preparadas para manejarem tais situações. A este respeito, Campos et al. (2011) destacam que avanços relativos ao cuidado em saúde mental podem estar vinculados a uma maior integração entre os profissionais da ESF, ou entre estes e os profissionais especializados, com discussão de casos em conjunto e o estabelecimento de parcerias em ofertas de ações visando o acompanhamento no território e a inserção dos usuários no serviço. Dado este contexto, as equipes da Atenção Primária, por atuarem junto às famílias e comunidades, com ênfase nas ações de promoção de saúde e prevenção de agravos, possuem papel importante diante do sofrimento humano, entretanto, sua atuação deve manter-se atrelada aos níveis secundário e terciário de atenção, uma vez que diversos casos demandam cuidados especializados em determinadas situações.

Sobre a rede de saúde mental da cidade em que foi realizado o estudo, de acordo com as informações disponibilizadas no site da prefeitura, o município conta com dois ambulatórios de saúde mental (sendo um regional e um distrital), 18 Residências Terapêuticas (sendo 7 sob gestão do município e 11 do Estado) e quatro Centros de Atenção Psicossocial (CAPS) (nas modalidades II, III, ad e i). Além disso, a nível estadual, a cidade dispõe de dois hospitais psiquiátricos (sendo um de internação total e outro de internação parcial), e de um 
hospital geral com unidade de internação psiquiátrica (Prefeitura Municipal de Ribeirão Preto, 2013; Prefeitura Municipal de Ribeirão Preto, s.d.).

Quanto às atribuições dos CAPS, tem-se que tais serviços devem atender urgências, acompanhar os pacientes mais graves, oferecer oficinas de trabalho, orientar a Atenção Primária, controlar medicações psicotrópicas de alto custo, realizar visitas domiciliares e atendimentos às famílias, realizar atividades culturais e educativas voltadas para o território enfocando a integração dos usuários na comunidade e sua inserção familiar e social (Mateus, 2013a; Ministério da Saúde, 2002; Ministério da Saúde, 2004a). Já a respeito das internações em hospitais psiquiátricos, conforme dispõe a Lei № 10.216 (2001), tem-se que a mesma é indicada apenas diante das situações em que os recursos extra-hospitalares se mostraram insuficientes, e, nesses casos, o tratamento tem como finalidade permanente a reinserção do usuário em seu meio social.

Considerando que o estudo foi desenvolvido numa cidade de médio porte, com população estimada de 604.682 habitantes (Instituto Brasileiro de Geografia e Estatística, 2010) infere-se a partir das entrevistas e da observação participante que a cobertura de serviços especializados em saúde mental ainda é significativamente insuficiente frente à demanda. Destaca-se, ainda, que o CAPSi do referido município atua especificamente com questões relativas ao uso de álcool e outras drogas, restando, portanto, apenas outros quatro serviços (dois CAPS e dois ambulatórios) voltados para demandas de saúde mental em geral. Relativo a este cenário, há a fala de Carolina, residente de Psicologia, que enquanto profissional em formação, relata com certo desconforto a carência de recursos para os cuidados em saúde mental no município, entretanto, ainda assim, os usuários são encaminhados, numa conduta quase automática.

Articulando os relatos dos profissionais acerca da insuficiência da rede e as informações retiradas de documentos oficiais acerca dos equipamentos integrantes da rede de cuidados em saúde mental, observa-se um cenário de fragmentação da rede de serviços que deveria ofertar cuidados em saúde mental no município. Tal fragmentação representa um obstáculo para a prestação de uma assistência continuada aos usuários que apresentam uma condição crônica (Mendes, 2011). Nesse sentido, conforme propõe o Ministério da Saúde (2002, 2004a, 2010), a expansão da ESF, a consequente implantação dos Núcleos de Apoio à Saúde da Família (NASF), a ampliação da cobertura pelos CAPS, a oferta de leitos em saúde mental nos hospitais gerais e a articulação destes equipamentos em rede, podem configurar alternativas para que sejam evitados os encaminhamentos desnecessários, visando aumentar a capacidade resolutiva da equipe local, fazendo face à complexidade das demandas de inclusão 
e reabilitação daqueles que, historicamente, estiveram à margem da sociedade por não corresponderem a um determinado padrão de ser e agir (Reinaldo, 2008; Silva \& Cardoso, 2013).

\subsection{Avaliação do cuidado ofertado em saúde mental pelas Unidades de Saúde da Família}

Esta categoria diz respeito à avaliação dos entrevistados quanto ao cuidado em saúde mental ofertado pela Unidade de Saúde da Família que frequentam ou onde trabalham.

“Olha, de maneira geral, eu acho bom. Eu acho até que é bom. Acho que pela... a gente consegue... Tem bons resultados, o paciente normalmente tem um bom controle das doenças. Como tem também outros profissionais ajudando, da Psico, da Terapia Ocupacional, enfim, outros profissionais envolvidos, eu acho que também ajuda bastante, Fonoaudiologia. Isso também ajuda na reabilitação do paciente, no tratamento. O próprio serviço de consultoria, então, o paciente tem a comodidade, né, no mesmo lugar que ele faz o seguimento, ele vem aqui, ele faz o atendimento secundário. Isso também é cômodo, é próximo da casa dele, o profissional que ele conhece, a gente ta acompanhando. Então, eu acho que em termos gerais, não é ótimo, às vezes deixa a desejar, a gente, principalmente na fase de descompensação aguda, às vezes a gente tem dificuldade, no caso de uma internação, essas coisas, mas... Aí já não é uma coisa que só depende da gente. Mas acho que precisamos trabalhar mais nessa parte de prevenção, promoção, prevenção, acho que essa parte que talvez fica... a parte de curativo, terapêutica, a gente até... lógico, tem sempre o que melhorar...”

(Maurício, Médico de Família)

"Ai, eu acho muito bom.Geralmente a gente não vê isso nos outros lugares, nos outros postinhos de saúde, então a atenção que o Núcleo oferece eu acho que é pra população inteira, né, eu acho que beneficia bastante. [...] Ai, assim, eu já fui atendida em hospital particular. Não é igual, mas chega perto. Porque é tudo limpinho, tem cuidado, os atendimentos que você tem, quando você precisa, eles sempre te atendem. Te atende... é... como eu posso falar? Parece que com amor e com carinho."

(Amanda, Usuária)

Mara: E como você avalia o cuidado em saúde mental que o Núcleo oferece?

Jorge: Pelo fato de ter essa supervisão (Consultoria Psiquiátrica), eu acho que ele faz uma articulação bem interessante, né, porque eles... a gente acolhe os pacientes, né, os casos leves são discutidos, mas são seguidos ali mesmo no Núcleo, são medicados, tal. A equipe é treinada pra identificar os casos mais graves, né, as situações agudas 
têm o treinamento para encaminhar pro hospital de urgência, né, de agudos, que é a Unidade de Emergência... E, os casos mais graves, os casos que extrapolam a competência da atenção primária também tem um treinamento pra como encaminhar isso daí, né?

(Jorge, Médico/Coordenador)

"Olha, dos pacientes de depressão leve, moderada, pacientes que já tem consciência do uso exato da medicação, que hoje não é um número pequeno, desde jovem até o idoso. Essas medicações básicas, consideradas, aí, como Sertralina, Fluoxetina, oferece um atendimento muito bom, adequado, porque se o paciente precisa de uma intervenção 'Ai, eu acho que ta me dando efeito colateral' ou 'Acho que a medicação ta pouca'. Eles vêm, conversam, a gente faz o encaixe, eles conversam, faz o reajuste da medicação. Então, assim, o acesso não é restrito. A pessoa vem, tem esse, essa porta de entrada e ele é bem cuidado."

(Cínthia, Auxiliar de Enfermagem)

Fátima: Olha, cem por cento eu acho que não dá pra ser. Porque são pessoas temporárias, pessoas que passam por aqui, não ficam. Todo mundo aqui ta de passagem, então, pra você criar um vínculo com psicólogo, por exemplo... Uma vem fica um ano, outra vem e vai embora depois de meses, outra vem e fica dois... Quer dizer, eu acho que numa crise, você pode contar com os profissionais, mas a longo prazo, não acho um tratamento correto, vamos dizer assim, correto é você ter um seguimento com uma pessoa só, criar um vínculo... [...] Porque também, o profissional passa a conhecer o paciente, né, aí vai embora, aí começa, aí até aquele profissional aprender a conhecer o paciente, ele vai embora. Aí vem outro e começa tudo de novo. Tem gente que até desiste. Cansa! Fala "ah, não, eu tava acostumado com fulano e agora vem outro?'

Mara: Mesmo com a equipe fixa?

Fátima: Não, a fixa, não! Mas, por exemplo, psicólogo, são só as meninas residentes. Fono, a mesma coisa. Fisio, a mesma coisa. É só enfermeiro e médico que é fixo, entendeu? Eu acho que a intenção é boa e que na hora na crise ajuda, mas a longo prazo, o tratamento a longo prazo... isso aqui teria que ser a entrada, o começo, depois teria que ter outro acompanhamento.

(Fátima, ACS)

"Olha, é claro que eu sou suspeito para falar, mas eu acho uma qualidade razoável e bem melhor do que você vê fora dessa área aqui, das equipes de Saúde da Família. Na realidade, nós temos alguns dados qualitativos e quantitativos que apontam que é uma qualidade, pelo menos, razoável de atendimento. Quer dizer, aqui não é o lugar onde as pessoas chegam chorando e você manda pra um serviço especializado, por exemplo; ou que você não acompanha alguém porque ele tem esquizofrenia, por exemplo, né?”

(Mário, Psiquiatra)

Mara: Uhum.... E você acha que o Núcleo dá conta da demanda que recebe, de saúde mental?

Raquel: Não. Tsc tsc. Você vê hoje, eu queria falar com você, mas todo mundo que a gente entra no consultório, quer falar um pouco de si, do problema que ta passando, 
muitas vezes não é nem problema clínico, né, mas a pessoa quer contar um pouco dela, do momento que ela ta passando... [...] Então, assim, tem muita demanda, a gente não dá conta.

(Raquel, Médica de Família)

Durante a realização das entrevistas, os participantes foram interrogados quanto a avaliação que fazem do cuidado em saúde mental recebido/ofertado pela USF. Assim, profissionais de diferentes áreas e usuários se posicionaram, explicitando suas opiniões, experiências e percepções acerca das ações desempenhadas em saúde mental.

O médico Maurício em seu relato qualifica o cuidado ofertado pela USF através do “controle das doenças” [sic] e considera que a potência do trabalho com profissionais de diferentes especialidades está na possibilidade de contribuição para a "reabilitação do paciente, o tratamento” [sic], evidenciando que sua avaliação está atrelada a um modelo de cuidado centrado no especialista, cujo objetivo é intervir na doença, reduzindo os sintomas e, neste enquadre, o que o serviço oferece é de qualidade. Para a usuária Amanda, o cuidado que recebe é "muito bom" [sic], uma vez que é atendida "com amor e com carinho" [sic] sempre que precisa. Infere-se que as considerações de Amanda corroboram com as de Maurício no sentido de que ambos avaliam que o serviço oferta uma atenção de qualidade quando é requerido. Entretanto, Amanda se vale da dimensão relacional do cuidado para avaliar a atenção recebida, ao passo que Maurício avalia o serviço a partir do prisma médicoassistencial. Destaca-se que o médico reconhece o vínculo, a continuidade da atenção e a possibilidade de cuidados no território como valores importantes da ESF e, nesse sentido, ele avalia que as estratégias de promoção e prevenção ainda estão aquém do desejado.

Na mesma perspectiva, Jorge e Cínthia, ao avaliarem o cuidado em saúde mental ofertado pela USF, consideram o aspecto clínico do cuidado, o que os leva a concluir que o serviço “oferece um atendimento muito bom, adequado" [sic], uma vez que os profissionais são treinados para acolher, medicar e encaminhar os usuários com queixa de sofrimento mental. Para Cínthia, muitos pacientes "já têm consciência do uso exato da medicação" [sic], recorrendo ao serviço apenas quando identificam algum efeito colateral ou avaliam que a medicação está insuficiente. Infere-se que as intervenções ficam restritas a acolhimento, medicalização e encaminhamento, evidenciando inclusive certa banalização destes procedimentos. Dado esse contexto, a auxiliar de enfermagem avalia que o paciente é "bem cuidado" [sic], uma vez que o acesso do usuário ao serviço é irrestrito e a medicação pode ser reajustada em conversa com o médico da unidade. Destaca-se que a questão formulada pela 
pesquisadora foi suficientemente ampla, oportunizando que a avaliação do cuidado abarcasse aspectos para além das intervenções sobre o sintoma.

A agente comunitária Fátima avalia que o cuidado em saúde mental ofertado pela USF “não é um tratamento correto" [sic] uma vez que, de acordo com sua compreensão, apenas os alunos, residentes e profissionais desta área específica da saúde estão suficientemente preparados para atender estas demandas. Seguindo esta lógica, Fátima conclui que o cuidado ofertado em saúde mental "não é cem por certo" [sic], uma vez que o serviço não dispõe de profissional contratado da área da saúde mental e os alunos e residentes, por estarem em formação, integram as equipes apenas temporariamente, o que compromete a manutenção dos vínculos e a continuidade do tratamento. Fátima evidencia a crença de que as ações de saúde mental não são da alçada da equipe fixa, a qual, na opinião dela, "na hora da crise ajuda" [sic] mas, em longo prazo, o paciente "teria que ter outro acompanhamento" [sic]. Nesse sentido, infere-se que seria de muita ajuda se parte da atuação dos alunos e residentes fosse direcionada para ampliar o olhar da equipe fixa sobre as questões de sofrimento mental, envolvendo uma compreensão do sofrimento como parte do que é ser humano, levando em conta o contexto mais amplo em que o sofrimento se manifesta, bem como a multiplicidade de fatores que interferem no processo saúde/doença. Assim, segundo Silva (2011), empreende-se um processo de abertura em direção à pessoa que busca cuidado, através da:

[...] possibilidade de cada profissional colocar-se diante do outro e compreendê-lo enquanto ser humano que possui potencialidades singulares, as quais podem ser apreendidas em cada encontro, anteriormente à aplicação de diagnósticos especializados e caracterizações patológicas que partem de uma visão generalista do adoecimento humano. (p. 181)

Na opinião de Mário, o cuidado em saúde mental ofertado pelas USFs estudadas tem uma "qualidade razoável” [sic] uma vez que são feitos esforços para qualificar a escuta dos profissionais com relação às queixas de sofrimento mental, de forma que as pessoas que chegam chorando não sejam encaminhadas indiscriminadamente para os serviços especializados. Já a avaliação de Raquel é que a USF tem encontrado dificuldades para dar conta da demanda que recebe. Segundo ela, muitas vezes, durante a consulta clínica, o paciente "quer falar um pouco de si, do problema que ta passando" [sic], o que sobrecarrega os profissionais. Nota-se pelos relatos dos entrevistados que a USF recebe, além de queixas pontuais de dor ou desconforto, uma grande demanda dos usuários por contato humano, por ser ouvido ou por compartilhar as situações vivenciadas. Infere-se que a sensação de solidão, de estafa ou de ausência de sentido da vida pode estar atrelada a um cenário de sobrecarga de 
tarefas, ritmo acelerado de trabalho, incentivo ao consumo, pressão excessiva visando à produção, relações interpessoais escassas e superficiais, desigualdade social, má distribuição de renda, entre outros aspectos contextuais. E, nesse sentido, sugere-se que tais aspectos precisam ser incluídos nos projetos terapêuticos enquanto questões importantes que atravessam o sofrimento mental, de forma que usuário e serviço de saúde possam firmar parcerias que visem o cuidado em saúde mental e a continuidade dos projetos de vida.

Dado este cenário e considerando que os profissionais também estão inseridos nesta cultura e, consequentemente, submetidos à mesma pressão, reitera-se, também neste contexto, a importância dos espaços de reflexão e de formação dentro da rotina de trabalho da equipe, o que abriria a possibilidade de ampliação da atuação do serviço de saúde, com ações voltadas ao território e que promovam a convivência, a solidariedade, o lazer, a reflexão, entre outros. De acordo com Ishara e Cardoso (2013), os profissionais necessitam de espaços que favoreçam o cuidado de sua própria saúde mental, o compartilhamento de experiências e a aprendizagem, consolidando práticas de cuidado que abarquem as dimensões da pessoa e estejam conectadas com a realidade comunitária e social. Assim, considerando que a medicalização não é um recurso que atua sobre o contexto mas sim sobre o indivíduo, proporcionando o alívio dos sintomas, é preciso investir esforços para auxiliar a pessoa em sofrimento a desenvolver outras estratégias de melhoria das condições de vida. Desse modo, uma importante ação dos serviços de saúde, especialmente os da Atenção Primária, seria auxiliar a comunidade no desenvolvimento de estratégias com potência de transformação sobre o contexto em que se vive.

Segundo Mateus (2013b), na sociedade industrial, os técnicos em saúde mental dispõem de pouco tempo para os pacientes e de poucas informações sobre eles, desempenhando suas ações de forma rotinizada, mantendo a medicação ou a internação, ou marcando novas consultas, como que para não "pecar por omissão” (pp. 96). Para Ribeiro, Medeiros, Albuquerque e Fernandes (2010), o uso da medicação em excesso pode, inclusive, estar associado a uma diminuição da capacidade de enfrentamento autônomo de parte dos adoecimentos e dores cotidianas. Nesses casos, o que pode ser observado é que a pessoa em sofrimento mental, apesar de estar sendo cuidada por serviços extra-hospitalares, ainda permanece dependente da lógica psiquiátrica, na medida em que associa sua melhora principalmente ao uso dos psicotrópicos.

Destaca-se que são evidentes os avanços decorrentes dos esforços de diferentes atores sociais visando à consolidação de um cuidado de base territorial pautado na perspectiva da integralidade a partir de ações de promoção e de prevenção. Entretanto, infere-se que ainda há 
um longo caminho a ser percorrido em direção à comunidade, transcendendo os consultórios. E, nesse sentido, considera-se que as propostas da Reabilitação Psicossocial têm muito a contribuir para a consolidação de um cuidado cujo foco seja a pessoa em seu contexto e não a doença, conforme apontam Alverga e Dimenstein (2006), Brêda et al. (2005) e Saraceno (2001). Intenciona-se, a partir dessa perspectiva, construir novas possibilidades de vida, que valorizem as condições concretas do cotidiano, investindo na autonomia e na reafirmação das singularidades (Amarante, 1995).

Ainda nesse contexto de avaliação dos cuidados em saúde mental, os participantes avaliaram a Consultoria Psiquiátrica, que foi reconhecida tanto por profissionais quanto por usuários como uma importante ferramenta de cuidado e, nesse sentido, objetiva-se colocar em discussão o formato e os propósitos desta atividade visando avançar nas reflexões acerca do papel do especialista em saúde mental inserido no contexto da Atenção Primária. Os trechos a seguir apresentam o posicionamento dos entrevistados acerca da Consultoria Psiquiátrica:

\begin{abstract}
“Ah, eu acho que, assim, (a Consultoria) é importante, os pacientes que vem aqui já conhecem o Dr. Mário como um médico deles também. Então, apesar de ter essa parte, também, de educação, da gente aprender como faz, eu acho que ele tem um bom vínculo com os pacientes. Então, eu acho que isso é bom. Acho que é importante [...] porque são casos mais específicos, casos às vezes difíceis e que ele... A pessoa trata aqui junto, perto da gente. [...] Porque, muitas vezes, quando a gente encaminha pro serviço de Psiquiatria, até no próprio (ambulatório secundário de saúde mental) que é perto, mas, a gente, geralmente, não sabe muito como que ta esse seguimento, né? Ou a gente não tem essa proximidade, aí, ele vem aqui e trata mais a clínica, né, ginecologia, hipertensão, diabetes. Então, quando ta fora, fica um pouco mais quebrado e quando ta aqui, acho que fica mais junto. Então, a gente consegue ver, acho, que mais integralmente o paciente."
\end{abstract}

(Fernanda, Enfermeira)

Fernanda destaca que a Consultoria Psiquiátrica constitui uma estratégia importante tanto do ponto de vista de formação dos profissionais para o atendimento dos pacientes, quanto do ponto de vista da assistência prestada aos usuários, possibilitando um olhar mais integral, menos fragmentado, sobre a pessoa em sofrimento. A enfermeira evidencia uma compreensão da Consultoria como um atendimento de nível secundário dentro da Atenção Primária e, infere-se que tal compreensão se ligue à crença de que os cuidados em saúde mental devam ser despendidos por serviços especializados e, portanto, por níveis de assistência que disponham de recursos mais complexos, ou seja, os níveis secundário e 
terciário. Nessa perspectiva, alguns profissionais se referiram à Consultoria como uma situação de aproximação do trabalho do especialista em saúde mental, por meio da qual temse a oportunidade de incorporar alguns conhecimentos desta área em sua prática, por exemplo, a identificação de sintomas e diagnósticos. Entretanto, pouco se referiu a este espaço como uma ferramenta que auxiliasse no desenvolvimento de ações mais amplas e comunitárias de promoção de saúde mental.

Dado este cenário, e considerando o histórico de conformação da Consultoria Psiquiátrica já mencionado anteriormente, compreende-se essa atividade como uma iniciativa precedente ao apoio matricial propriamente dito. De acordo com Campos et al. (2011) o apoio matricial é "um arranjo que visa dar suporte às equipes da Atenção Primária através do compartilhamento de situações cotidianas de trabalho produzindo uma corresponsabilização pelos casos” (p. 4648), podendo acontecer na forma de discussões compartilhadas de casos, intervenções conjuntas no território, atendimento conjunto, planejamento de ações ofertadas visando ao aumento da capacidade resolutiva da equipe, à aproximação e à desfragmentação entre os serviços da Atenção Primária e os serviços especializados, à melhoria da clínica dos atores envolvidos, à ampliação e à qualificação das ofertas no território e à capitalização de saberes técnicos.

Jorge et al. (2013) destacam a potência da prática do matriciamento para possibilitar mudanças no fluxo burocrático e hierárquico dos usuários na rede e na lógica dos encaminhamentos dos casos atendidos nas USFs e nos serviços especializados. Para estes autores, o trabalho em saúde é constituído pelos diversos encontros e pelas múltiplas visões sobre a relação entre trabalhador e usuário. Simultaneamente a relação terapêutica também é permeada por dor, sofrimento, vivências e percepções de vida, aspectos a partir dos quais os saberes e práticas em saúde mental precisam estabelecer mecanismos para ampliar o olhar para dimensões assistenciais, subjetivas, intersubjetivas e sociais.

Assim, compreende-se o apoio matricial como um arranjo inovador na medida em que rompe com as práticas asilares e coloca como objeto de sua atuação a existência-sofrimento em relação com o corpo social. O objetivo do matriciamento nesta perspectiva é a emancipação social do usuário, sendo decisiva sua participação no tratamento (Costa-Rosa, 2000; Minozzo \& Costa, 2013). O trabalho em equipe, neste cenário, pressupõe uma atuação plural e integral, a partir de uma multiplicidade de enfoques, abrindo caminhos para reflexões acerca das relações estabelecidas pelos usuários consigo, com o medicamento, com a família, com o tratamento e com os próprios profissionais da saúde, visando à inserção da pessoa em sofrimento na comunidade (Costa-Rosa, 2000; Jorge et al., 2013; Minozzo \& Costa, 2013). 
Tendo em vista a literatura e as informações obtidas por meio das entrevistas e da observação participante, depreende-se que as unidades estudadas dispõem, através da Consultoria Psiquiátrica, de um recurso potente e inovador tanto de cuidados quanto de formação, indicando avanços significativos no sentido do que é preconizado pela Reforma Psiquiátrica e pelas propostas de fortalecimento da Atenção Primária. Todavia, observa-se ainda que este espaço frequentemente é dominado pelo saber especializado, o que dá margem para que seja significado pelos profissionais como atenção de nível secundário dentro da Atenção Primária. Infere-se, portanto, que apesar do caráter inovador deste arranjo e do desejo legítimo de superação do especialismo, no cotidiano do serviço muitas práticas acabam sendo capturadas pela lógica de cuidados da doença. Gonçalves (2013) salienta que, nesses espaços, antes da teorização das situações discutidas, é importante o exercício de resgatar alguns tópicos como: o motivo pelo qual aquele caso deve ser discutido (com a demanda do profissional da Atenção Primária e do usuário ou familiar em questão); a descrição da situação atual (com elementos da realidade, problemas concretos, dados sociofamiliares); recursos terapêuticos e de suporte disponíveis naquele território ou serviço de saúde, e, finalmente, os objetivos que a equipe pretende alcançar com a intervenção.

Alguns profissionais durante as entrevistas se posicionaram sobre o formato da Consultoria Psiquiátrica, fazendo referências ao histórico da atividade desde sua configuração inicial, na época em que foi implantada, até a maneira como está estruturada atualmente.

“Nós participávamos antes da Consultoria Psiquiátrica [...] não da consulta conjunta. [...] Então, o que fazia? A gente tinha uma reunião antes do paciente entrar. Passava o caso do paciente, discutia, aí o pessoal (agentes e auxiliares de enfermagem), assim, saía e a pessoa (paciente) entrava com um número menor de profissionais pra fazer a consulta conjunta. Mas acabou isso. Sei lá. Foi, sabe, a gente foi deixando terminar e agora é difícil pra recuperar. Porque eles tão numa outra dinâmica também. Eles estão mais em atendimento, menos discussão, assim, de caso, né? [...] então, quando nós tivemos oportunidade de participar, os agentes comunitários, a gente aprendeu muita coisa, assim, sabe, a gente... [...] Eu sinto (falta desse espaço). Sinto. Eu acho assim que... não de participar da consulta, porque eu acho que é muito invasivo, muita gente. E a gente não precisa saber, né, não precisa... mas, assim, como era antigamente, que ele... A gente passava, passava as dúvidas que a gente tinha, tudo. Até o modo, o meio, assim, de como abordar, tudo. E ele (supervisor), ele, nossa, era muito bom. A gente aprendeu muito com ele. Aprendeu com os casos, né, mas, depois, acabou, assim, a gente ficou meio... [...] E era bom, muito bom.”

(Tereza, ACS)

“Hoje já mudou, a Consultoria Psiquiátrica tem um aspecto mais clínico mesmo, mais voltado pra residência, então, a gente não tem tanto vínculo mais. [...] Então, assim, 
eu não tenho tanta proximidade hoje com esses pacientes. [...] Muitos eu não sei o que trata, ou porque que vem na Consultoria. Os mais antigos eu sei. Os mais recentes eu não fiz o acolhimento, foi algo que já foi detectado em consultório para a Consultoria, eu não tenho conhecimento. [...] Então, assim, eu acho que é uma coisa que ficou meio perdida, né? [...] a remodelação foi dando abertura mais pro grupo profissional de residentes, multis e quem ta aí ia participar, e, a não participação da equipe, que ta no dia-a-dia. Foi isso que aconteceu."

(Cínthia, Auxiliar de Enfermagem)

Silvana: Nós participávamos da Consultoria. Mas, aí, acabou ficando mais pra equipe técnica mesmo. Eu não me sentia bem. Aí, depois, resolveram trazer, né, expor o paciente ali no meio de um monte (ênfase) de aluno que... cai ali de pára-quedas, entendeu?

Mara: Por isso que você não se sentia bem?

Silvana: Falta de respeito também, né, com o próprio paciente, né? Eu acho.

Mara: Mas... Eles perguntam pro paciente se ele topa, não é?

Silvana: Ai, e (o paciente) vai falar que não? Depende daquilo, né?[...] Agora, tem paciente que se sente constrangido. A gente que sabe das coisas, às vezes, até mais. Às vezes ele fala pra gente e não fala no consultório, durante a consulta médica.[...]

Mara: E você acha que as Consultorias eram de ajuda pra sua prática?

Silvana: Ai, eu aprendi bastante, sim. Eu aprendia muito, assim. Ah, a distinguir transtorno, o que que é, o que que não é. Era uma aula que a gente tinha, assim. Uma aula na prática mesmo, né? Você... Era uma troca de saberes, né? Mas eu sinto falta, sim. Sabe, da participação da Psiquiatria.

(Silvana, ACS)

"É uma contradição (os agentes não poderem participar da Consultoria). Você ta indo na contramão da Estratégia (Saúde da Família), né? Você quer tirar a figura do médico como centro da atenção, mas, ao mesmo tempo, você reforça isso."

(Gabriela, Enfermeira)

Geraldo: Eles (os demais ACS) sentem falta. Eles devem relatar pra você, acho.

Mara: Uhum. É, acho que vocês (ACS) trazem informações importantes...

Geraldo: Porque eles passam na casa da pessoa... [...] (Os ACS trazem) O social, né? Se não fica muito medicamentoso.

(Geraldo, ACS)

Tereza, Cínthia e Silvana relatam que quando a Consultoria Psiquiátrica foi implementada contava com a participação de todos os membros da equipe mínima, incluindo agentes comunitários e auxiliares de enfermagem, objetivando a capacitação dos profissionais para o contato com o sofrimento mental. Para elas, esta atividade constituía um espaço valioso de troca e aprendizado, em que os membros da equipe tinham a oportunidade de se aproximarem do trabalho do especialista em saúde mental, conhecendo sua dinâmica e aprimorando seu entendimento sobre o sofrimento mental. Com o passar do tempo, de acordo 
com Tereza, esta atividade passou a funcionar "numa outra dinâmica [...] mais em atendimento, menos discussão” [sic], tendo a participação apenas dos médicos, enfermeiros e residentes. Segundo Cínthia, foi-se “dando abertura mais pro grupo profissional de residentes, multis, [...] e, a não participação da equipe, que ta no dia-a-dia” [sic]. Observouse, então, uma importante transformação do caráter da atividade, que, com o tempo, centrouse principalmente na tarefa de qualificação dos profissionais de nível superior da equipe (médico e enfermeiro) e de formação dos alunos que integram as USFs durante a residência, aprimoramento ou estágios curriculares.

Infere-se que ao impedir a participação dos auxiliares de enfermagem e agentes comunitários na Consultoria Psiquiátrica, reproduz-se a lógica de que os cuidados em saúde mental competem aos profissionais especializados ou, no mínimo, com nível superior. Reitera-se, assim, a crença de que a saúde mental é uma área muito complexa e até enigmática, uma vez que os protocolos e procedimentos são insuficientes na grande maioria dos casos, o que pode reproduzir uma história de segregação e preconceito. Nesse sentido, tem-se a fala da enfermeira Gabriela afirmando que a forma como está estruturada a Consultoria Psiquiátrica atualmente configura uma “contradição” [sic], pois uma vez que os auxiliares de enfermagem e agentes comunitários estão impossibilitados de participar, se "está indo na contramão da Estratégia (Saúde da Família)” [sic]. Aponta-se assim que, se tais profissionais tivessem a possibilidade de integrar os espaços de cuidado da saúde mental, muitos passos poderiam ser dados em direção a práticas mais comunitárias e integrais que levassem em conta o contexto familiar e social no qual emerge o sofrimento. E, ainda, como uma via de mão dupla, ao integrarem os espaços de discussão e elaboração de estratégias de cuidado em saúde mental, tem-se que os profissionais tendem a se considerar com mais recursos para realizar o acompanhamento dos usuários com queixas de sofrimento mental, o que corrobora o relato dos agentes comunitários e auxiliares de enfermagem que integram as equipes há mais tempo e tiveram a oportunidade de participar desta atividade após a sua implementação.

Ainda sobre essa questão, Geraldo acrescenta que a participação dos agentes comunitários nesses espaços possibilitaria que os aspectos do contexto, ou seja, "o social” [sic], fossem mais explorados durante os processos de planejamento, reflexão e avaliação de estratégias, pois, caso contrário, "fica muito medicamentoso" [sic]. Pupin-Andrade (2013) destaca que a pouca participação dos agentes comunitários nas atividades de grupo e a centralização de suas práticas nas visitas domiciliares corrobora com o afastamento deste profissional de um perfil político/comunitário. A autora, assim como a enfermeira Gabriela, identifica a contradição existente no trabalho do agente comunitário uma vez que ao ser capturado por um trabalho que 
prioriza aspectos individuais e burocráticos, ele perde a potencialidade de desenvolver uma atuação que poderia incluir aspectos como a identificação com a comunidade, a solidariedade e a politização. Sugere-se que tanto o agente comunitário quanto o auxiliar de enfermagem carregam um "saber em saúde” que tem muito a contribuir para a oferta de um cuidado mais amplo, uma vez que agregam informações contextuais e relacionais, oportunizando a descoberta dos "recursos escondidos na comunidade" (Lancetti, 2001, p. 107) e impulsionando o desenvolvimento de outras estratégias de cuidado, para além do atendimento conjunto.

Assim, retomando a entrevista de Geraldo e considerando o contexto da Consultoria Psiquiátrica, supõe-se que agregar “o social” [sic] a esta atividade implica em conhecer os recursos disponíveis no território (escolas, ONGs, praças, cooperativas de trabalho, igrejas) com os quais há a possibilidade de firmar parcerias; investigar, diante de cada caso, as redes de relações interpessoais estabelecidas pelo usuário, ou seja, familiares, amigos, vizinhos, entre outros que podem configurar fontes de suporte para continuidade do percurso de vida; investigar as características do contexto que podem estar contribuindo para a manifestação do sofrimento como, por exemplo, sobrecarga de tarefas, conflitos familiares, solidão, desemprego, comorbidades ou vícios; considerar as características do usuário como situação financeira, autonomia, sociabilidade, manias e medos; conhecer os projetos de vida do usuário com relação a aspectos como emprego, estudos, moradia, prática de atividades físicas e de lazer; considerar os desejos e fantasias do usuário com relação ao tratamento, desmistificando a loucura; desenvolver projetos conjuntos entre equipe e comunidade a partir da observação das necessidades locais; trabalhar de forma articulada com os demais serviços que compõem a rede de cuidados, visando à elaboração de um plano de trabalho único e integrado para cada usuário. Considera-se que tais aspectos são essenciais para a oferta de ações que correspondam às necessidades das pessoas e para a mudança de paradigma em saúde mental que almeja a parceria entre profissionais e usuários, possibilitando a apropriação pela comunidade do espaço do serviço de saúde e, igualmente, do serviço de saúde do espaço da comunidade, ambos trabalhando para melhores condições de vida.

Quanto à perspectiva dos usuários acerca da Consultoria Psiquiátrica, têm-se os relatos:

Mara: O que você acha da Consultoria?

Amanda: Então, eu passei com ele uma vez só. Agora, eu vou passar de novo. Dia 29 eu tenho retorno. [...] Ah, eu gostei. Assim, eu não queria passar, mas eu passei mesmo assim. 
Mara: E porque você não queria?

Amanda: Ai, eu não sei explicar. Chorei. Eu não queria de jeito nenhum passar com ninguém. Nem com psicóloga, com ninguém eu queria conversar. Aí, o Dr. Maurício foi, conversou comigo, aí eu passei com ele.

Mara: Mas como foi? Você estava em consulta com o Dr. Maurício e você chorou e ele sugeriu que você passasse pelo Dr. Mário?

Amanda: Não. Na realidade, esse dia era com o Dr. Mário. A primeira vez. E eu não queria passar. De jeito nenhum! Porque além de estar o Dr. Mário, tinha outros médicos lá. Aí eu não queria passar porque tinha muita gente. Aí o Dr. Maurício veio, conversou comigo. [...] Conversou comigo e aí eu passei. [...]

Mara: E você não tinha opção de pedir pra só conversar com o Dr. Mário? [...]

Amanda: Então, como era primeira vez, era melhor por causa, pra todo mundo conhecer meu caso. Que eu era muito nova, então todo mundo tava... Tinha uma psicóloga lá e ela queria conversar comigo, queria saber do caso... Aí o Dr. Maurício pediu pra mim tentar entrar. Aí eu entrei. Mas mesmo assim, eu entrei chorando, entrei tremendo, mas entrei.

(Amanda, Usuária)

“Agora eu não quero nada disso, eu quero só fazer alguma coisa que me fizesse bem, porque eu também podia emagrecer um pouco, ficar até mais bonita. E, quem sabe com o tempo, né, eu não sei... Eu acho que os remédios eu não vou conseguir tirar, não. Você viu? Ele (residente da Psiquiatria durante a consultoria) acrescentou um e eu não consegui tirar o que eu tomava! Ele mandou eu tirar aquele e ficar só com esse mas eu não consegui tirar. [...] Mas agora ele mandou eu tomar um e meio, eu não sei se eu tomo um e meio, isso eu to em dúvida. Eu já vou ficar com dois e meio, mais aquele em gota. [...] Então, não sei se eu não tomo meio, falo que eu to tomando um e meio, né? [...] A não ser que a hora que ele vê meu exame, ele vê aquilo e não tirar de novo. Mas aí vai acontecer aquele detalhe, aí eu já to acostumada com um e meio, porque negócio de você acrescentar remédio, você tirar o remédio é que é o problema. E depois pra tirar o meio? Eu acho que eu vou falar a verdade pra ele 'Ó, eu não acrescentei meio'."

(Beth, Usuária)

"Porque, às vezes, eu não fico falando a verdade pros médicos, tudo o que eu sinto, que nem esse negócio da aranha...[...] mas eu fiquei com medo de falar, dele achar que isso não é normal. "A Beth ta louca mesmo. Vamos internar ou então vamos mudar a medicação. Pode ser que essa paranóia da Beth, essa visão, pode ser do remédio que ta dando isso". Mas foi só da aranha, entendeu, não teve mais outro episódio. Só que eu achava que a aranha tava ali e ela tava querendo pular em mim [...].”

(Beth, Usuária)

As vinhetas de Amanda e Beth trazem a perspectiva dos usuários acerca da Consultoria. O relato de Amanda corrobora com o de Silvana apresentado anteriormente no que diz respeito ao desconforto por ser consultada por muitos profissionais ao mesmo tempo, inclusive alguns desconhecidos. Esta usuária refere que estava relutante quanto a entrar na 
Consultoria, mas cedeu dada a solicitação do médico, o qual justificou que, por ela ser muito jovem, seria interessante que a equipe conhecesse seu caso. Amanda acrescenta: "eu entrei chorando, entrei tremendo, mas entrei." [sic], explicitando o sofrimento vivenciado diante da situação. Silvana, agente comunitária, em seu relato afirma que a possibilidade de solicitar ser consultada individualmente pelo psiquiatra não é factível, pois o paciente "depende daquilo" [sic] e dificilmente contestará a solicitação do médico. A agente acrescenta ainda que considera uma "falta de respeito" [sic] com o paciente, que é "exposto no meio de um monte de aluno" [sic].

No caso de Beth, além das informações obtidas por meio da entrevista com a usuária, têm-se os dados obtidos através da observação participante realizada pela pesquisadora da primeira Consultoria Psiquiátrica em que a usuária compareceu. Nessa ocasião, a médica de família, ao apresentar o caso para os profissionais presentes, relatou que fizera o encaminhamento da usuária para o atendimento especializado devido a pouca adesão da mesma aos tratamentos propostos durante as consultas clínicas tradicionais. Tanto em sua entrevista quanto na Consultoria, destaca-se que Beth expressou o desejo de diminuir a quantidade de remédios e, paralelamente, de procurar outras atividades que lhe fizessem bem, como academia e yoga. Na ocasião da Consultoria, foi averiguado pelo médico que ela estava tomando uma dosagem inferior à prescrita de determinado medicamento. Apesar do desejo de não aumentar a dosagem, foi indicado que seguisse a prescrição inicial. Durante a entrevista, ocorrida posteriormente à Consultoria, ainda resistente sobre aumentar a medicação, Beth conjeturou com a pesquisadora sobre acatar, ou não, a prescrição dos médicos. Nesse contexto, infere-se que os profissionais da Consultoria não foram suficientemente capazes de ouvir a demanda de Beth e explorar as alternativas de cuidado trazidas por ela. Além de a intervenção proposta estar principalmente centrada na medicação, sem que fossem explorados os recursos do contexto e as alternativas trazidas pela usuária, a comunicação entre Beth e a equipe foi insuficiente, de forma que não houve uma negociação efetiva e a usuária acabou sozinha decidindo o rumo de seu tratamento.

Segundo o Ministério da Saúde (2005b), o trabalho em equipe e o exercício da clínica ampliada pressupõem que o profissional de saúde desenvolva a "capacidade de ajudar cada pessoa a transformar-se, de forma que a doença, mesmo sendo um limite, não a impeça de viver outras coisas na vida.” (p. 4). Esta postura profissional torna-se especialmente importante nos casos de doenças crônicas, pois, assim, o usuário pode ser ajudado a reinventar-se, para além dos sintomas, evitando que se dedique principalmente à doença e sendo incentivado a encontrar outras atividades e fontes de satisfação e bem-estar. 
Em outro trecho de sua entrevista, Beth relata que nem sempre fala tudo o que sente para os médicos, pois tem medo de ser interpretada como "louca” [sic] e ser internada ou ter sua medicação modificada. Infere-se, portanto, que numa lógica de cuidado em que os sintomas são enfatizados e as potências são pouco fomentadas, as possibilidades de intervenções se restringem a internação e medicação, corroborando com a impressão de Beth sobre o serviço e justificando seu receio de relatar tudo o que sente. Supõe-se que numa relação equipe-usuário em que possa haver uma corresponsabilização pelas situações apresentadas, não haveria necessidade da usuária omitir o que sente. Ao guardar para si a dúvida sobre o enlouquecimento, Beth fica sozinha com a sensação de estranhamento de si mesma, podendo, inclusive, empreender um processo de amplificação dessa sensação de loucura, o que pode implicar em maior sofrimento e isolamento. A possibilidade de dividir com os profissionais de saúde a situação experienciada com a aranha poderia abrir espaço para um diálogo que desmistificasse a loucura e, até mesmo, as crenças acerca da internação. Ao intervir principalmente por meio dos protocolos já estabelecidos, o serviço se omite da função de se colocar junto do usuário, dentro do contexto vivido, buscando significados para as situações relatadas.

Para Santos (2013), tratar os sintomas é a primeira tarefa do serviço de saúde, todavia, seria desejável agregar a esta, ações voltadas para ajudar o usuário a encontrar, ou a reencontrar, seu lugar social, o qual possa ocupar como membro estável de um grupo. Gonçalves (2013) aponta que um instrumento fundamental para organização do trabalho matricial é o Projeto Terapêutico Singular, o qual, segundo o Ministério da Saúde (2013) trata de “estratégia de cuidado que articula um conjunto de ações resultantes da discussão e da construção coletiva de uma equipe multidisciplinar e leva em conta as necessidades, as expectativas, as crenças e o contexto social da pessoa ou do coletivo para o qual está dirigido" (p. 55). Dessa forma, olhando para Beth em seu percurso de vida, poder-se-ia constatar que se trata de uma usuária bem orientada, chefe de família, que dispõe de considerável autonomia e de muitos recursos como dirigir, tratar das tarefas domésticas, fazer compras, atender às necessidades dos filhos, cuidar do neto, entre outros. E, assim, talvez houvesse a possibilidade de conversar com Beth sobre as possíveis interpretações para o episódio da aranha e até esclarecer que, dado seu contexto, a internação não é um recurso considerado, e ainda, discutir e avaliar conjuntamente os efeitos, benefícios e dificuldades em relação ao aumento da medicação nesta situação.

Para Pinto et al. (2012), a possibilidade de exercer uma clínica solidificada em saberes e práticas inovadores está atrelada a interposição de arranjos de trabalho e gestão que se 
transversalizem pela subjetividade e pela cultura de forma a promover o encontro entre a necessidade de se equilibrar psiquicamente, interagir socialmente com maior autonomia e efetivar projetos terapêuticos integrais. Dado este cenário, destaca-se que a medicalização e o encaminhamento para serviços especializados são entendidos como ferramentas importantes do processo de cuidados em saúde mental, entretanto, como fica evidente no caso de Beth, tais alternativas são insuficientes diante da complexidade da situação vivenciada. Vale ressaltar que a Consultoria, ao se propor a supervisionar os casos de sofrimento mental, realiza relevante tarefa ao ministrar as medicações e tratar da articulação com outros serviços da rede, evitando encaminhamentos desnecessários e aprimorando o olhar de determinados profissionais sobre as demandas de saúde mental. No entanto, dado este cenário, considerando o contexto da ESF, infere-se que seria bastante válido o desenvolvimento e/ou apropriação de espaços, dentro da rotina da USF, que incluam equipe e comunidade, onde coubessem reflexões sobre o propósito das práticas de cuidado e a exploração de estratégias não medicamentosas que enfoquem o contexto e as relações.

\subsection{Transformações do cuidado em saúde mental: Concepções dos participantes acerca da pessoa em sofrimento mental e da viabilização da desinstitucionalização e da Reabilitação Psicossocial}

Esta categoria abarca a compreensão dos entrevistados acerca dos processos de transformação que vêm ocorrendo na área da saúde mental por meio da Reforma Psiquiátrica. Considera-se que conhecer as concepções que atravessam as práticas é fundamental para o processo de aproximação e questionamento das ações em saúde.

Conforme ilustram os relatos a seguir, observou-se que ao longo das entrevistas os participantes explicitaram a maneira como compreendem a pessoa em sofrimento mental, realizando comparações entre a doença física e a doença mental e abordando temas como medos e preconceitos.

"Nossa, eu acho que tem tudo a ver, assim, o que ta acontecendo agora, assim (sobre a Reforma Psiquiátrica e as transformações quanto ao cuidado da saúde mental). Tem que por, mesmo, tem que por nas ruas, tem que por pra sociedade. Tem que aceitar, né? Eu acho que, assim, a sociedade ta aceitando tanta coisa... Né? Ultimamente... E 
não vai aceitar um paciente, uma pessoa que tem problema psiquiátrico? Isso aí não... Se a pessoa ta bem controlada, se ela, né, se ela toma a medicação dela certa, ela tem que ter uma vida normal. Ela não pode ser excluída, né? Ela tem todos os direitos, ela, eu acho que é muito válido, assim... [...] Eu acho e a gente poder educar os filhos da gente, né, vendo essas pessoas, convivendo, né, nesse meio, com pessoas diferentes, né, porque ninguém é igual a ninguém, né. E eu acho que a gente tem que começar desde a casa da gente a educar, né, pra aceitação, porque... Antigamente era tudo muito, muito radical, assim, sabe, a pessoa quando era diferente, ela não podia ficar misturada, né, com outras. E... Nossa senhora, é um absurdo! [...] E acho que a inclusão é tudo, assim, porque eu acho que tem muitas maneiras de incluir. [...] Mas eu acho que na sociedade você tem que... você tem que enfiar a pessoa ali, né, mostrar que ela existe, que ela é um ser humano que ela ta ali também, que ela tem direito das mesmas coisas que a gente tem, né? Porque eu acho que até um tempo atrás era meio excluído, né? E a gente encontra preconceito dentro do serviço de saúde também."

(Tereza, ACS)

“Todo mundo tem uma loucura, não é? Até esses psiquiatras também devem ter suas loucuras. Você acha que não? Você acha que todo mundo não tem suas manias? Todo mundo tem suas manias."

(Beth, Usuária)

Fátima: (Pacientes) psiquiátricos, que eu lembre... [...] até tem, mas é aquele deprimido, que toma o seu antidepressivo ali quietinho, não é problemático, assim, você entendeu? [...]

Mara: Os "depressivos quietinhos" você não conta como da saúde mental?

Fátima: Ahhh, não. Você sabe por que que não? Não, porque, por exemplo, eu tomo antidepressivo. Eu já tive síndrome do pânico... e eu não me acho um paciente psiquiátrico, você entendeu? Num sei, eu acho assim que a pessoa pode ter uma deficiência, vamos supor, assim, mas ela toma o remedinho dela, não traz grandes problemas pra ninguém, segue a vida dela normal. Da mesma forma como tem um monte de gente que toma remédio para pressão alta, eu tomo Sertralina, porque eu tenho depressão, eu tive síndrome do pânico, e não adianta ficar sem remédio porque eu entro em depressão. Eu já até tentei ficar sem. E a mesma coisa é com o hipertenso. Ele tem que tomar remédio porque se não a pressão dele sobe. E ele traz trabalho pra alguém? Não traz! Ele dá problema pra alguém? Então, eu acho que paciente psiquiátrico mesmo é aquele que interna, aquele que dá trabalho, aquele que pensa em se matar, você entendeu? Seria um grau mais...

(Fátima, ACS)

“Esses casos... É diferente de você acompanhar um hipertenso, um diabético, porque você tem mais, mais... eu não diria capacidade, mas é, eu acho que o assunto é mais fácil pra gente conversar. Você sabe o que é necessário, o tratamento a gente tem mais conhecimento. Passando pra saúde mental, pra nós já é muito complicado.”

(Antônio, ACS)

"O que eu costumo dizer pra todo mundo: Se você tiver uma pneumonia, você não vai no médico? Você não toma a medicação pra você melhorar? Se você tiver uma diabetes, você não vai no médico? Você não toma medicação? Então, na saúde 
mental, você vai, toma medicação, a mesma coisa. Então, quer dizer, a doença em si, ela não tem nada de, substancialmente, diferente. A única coisa é que ela dá uma desestrutura, né, na parte mental que a gente... Eu não sei qual é o preconceito mesmo que a gente tem com relação a isso. Então... Mas é uma doença como qualquer outra. Não é uma doença moral, por exemplo, né? Que no início pensava. Então é... Eu até gosto, sabe, de atender, de conversar com esses pacientes."

(Jorge, Coordenador)

As vinhetas das entrevistas de Tereza e Beth são ilustrativas de uma compreensão ampliada de saúde mental, demonstrando compreender a pessoa em sofrimento como alguém que demanda cuidados, entretanto, é capaz de estabelecer relações interpessoais, integrar ambientes coletivos e assumir papéis sociais. Assim, observa-se que, ao menos no âmbito do discurso, as propostas da Reforma Psiquiátrica vêm sendo incorporadas na forma como profissionais e usuários compreendem o sofrimento mental. Tereza evidencia um entendimento da Reforma Psiquiátrica como um processo mais amplo e complexo do que o fechamento dos leitos em hospitais psiquiátricos e a abertura de serviços substitutivos como, por exemplo, as Casas Terapêuticas. Para ela, este processo implica numa transformação cultural, que pode começar “desde a casa da gente” [sic] através da educação para a convivência e a aceitação das diferenças, uma vez que “ninguém é igual a ninguém” [sic]. A agente ressalta a medicação, o tratamento, como parte importante do processo de cuidado, entretanto, dá indícios de que a ação medicamentosa deve conectar-se a outras alternativas, comprometidas com um acompanhamento longitudinal, levando em conta as particularidades de cada situação, bem como o contexto histórico de preconceito e segregação.

Beth analisa que “todo mundo tem uma loucura” [sic], evidenciando uma compreensão de sofrimento mental como intrínseco à condição humana, associado às relações e aos contextos. Esta perspectiva corrobora com a dificuldade de se fazer uma distinção objetiva entre pessoas em sofrimento e pessoas “saudáveis”, além de evidenciar a limitação das alternativas estritamente medicamentosas. Já Fátima, contrariamente à Beth, dá indícios de que sua compreensão de pessoa em sofrimento mental liga-se aos casos mais graves, ou seja, “aquele que interna, aquele que dá trabalho, aquele que pensa em se matar” [sic]. Fátima, revelando sua história pessoal, relata que já teve síndrome do pânico e que, atualmente, faz uso de antidepressivo, uma vez que, segundo a mesma, entraria em depressão se interrompesse o uso do psicotrópico. E, assim como a agente, muitos outros usuários “tomam seus remedinhos, sem trazer grandes problemas pra ninguém” [sic], não sendo considerados por Fátima como “pacientes psiquiátricos” [sic]. De acordo com o ponto de 
vista da agente comunitária, a pessoa com depressão, assim como a com hipertensão, ao seguir o tratamento corretamente, consegue manter sua situação estabilizada. Questiona-se, a partir desta perspectiva se o dito paciente deprimido, “quietinho” [sic], estável, deverá tomar a medicação continuamente. Aumentar-se-á a dose sempre que houver necessidade? Quais outras iniciativas podem ser associadas à medicação, enquanto a pessoa "não traz grandes problemas pra ninguém” [sic], evitando o agravamento da situação ou visando à suspensão dos remédios?

Neste contexto, dado o histórico de preconceito e discriminação das pessoas em sofrimento mental, acredita-se que o fato de Fátima não identificar o usuário deprimido como paciente psiquiátrico pode estar associado a um medo de também reconhecer-se enquanto tal. Ainda que revelando o diagnóstico de um transtorno mental, a agente realiza uma diferenciação entre os quadros, como se buscasse um distanciamento com relação aos casos mais graves, desvelando um movimento de atribuir a loucura ao outro como forma de afastarse dela. Como consequência, supõe-se que a agente acaba por se distanciar das questões relativas ao cuidado das pessoas em sofrimento mental, pois, de acordo com a perspectiva evidenciada, apenas os casos mais graves são considerados de saúde mental e estes, por sua vez, exigem cuidados mais especializados para os quais ela não se considera qualificada.

Assim como Fátima, Antônio e Jorge também fizeram comparações entre saúde física e saúde mental, diferenciando ou aproximando os conceitos. Para Antônio, "é muito complicado" [sic] quando o caso é de saúde mental, pois ele não se considera capaz de lidar com a situação. Segundo ele, lidar com a doença física é mais fácil, pois o tratamento é conhecido e ele sabe quais orientações deve dar ao paciente. Neste contexto, questiona-se: Por que é mais fácil conversar com o usuário com hipertensão ou diabetes? Qual conhecimento é necessário adquirir, na opinião do agente, para o contato com o sofrimento mental? Quais as crenças sobre o saber dos profissionais especializados? Considerando o sofrimento mental como uma condição inerente ao ser humano, por que, ainda assim, é difícil entrar em contato com o sofrimento do outro? Hipotetiza-se que, no que diz respeito ao sofrimento mental, o medo de entrar em contato consigo mesmo através do sofrimento do outro provoque a paralisação do profissional e o afastamento da situação. Assim, paradoxalmente, parece mais fácil conversar sobre doenças como hipertensão e diabetes, mesmo que nunca tenha experienciado, por exemplo, situações de controle rigoroso de açúcar e sal na alimentação, ou ainda, a rotina de aferição e cuidados quanto à pressão arterial ou às taxas de glicose no sangue. Infere-se que num modelo de cuidado em que para cada queixa existe uma conduta, de fato a tarefa de atenção à saúde mental torna-se complicada. Faz-se necessário transcender 
este modelo e avançar em novas formas de fazer saúde, onde haja espaço para a dúvida e o fazer compartilhado.

Jorge pondera que a doença mental é “como qualquer outra” [sic] e deve ser cuidada como tal, ou seja, segundo ele, procura-se um médico e toma-se a medicação. Ao mesmo tempo em que Jorge avança no sentido de desmistificar a loucura, abordando-a como uma condição que necessita de cuidados e que contém potências, também reduz as possibilidades de ajuda à consulta médica e ao tratamento medicamentoso. Neste sentido, esta fala é representativa de um processo de transformação em curso, em que são observados passos na direção da compreensão do sofrimento mental como uma condição humana, porém, ainda restringindo as possibilidades de ajuda à Medicina e ao saber especializado.

Sobre o medo e o preconceito despertados pelo contato com o sofrimento mental, os entrevistados relataram:

“Eu, pra mim é normal, assim, eu não tenho medo porque eu nunca me vi numa situação nenhuma de perigo, assim... [...] Assim, não tenho medo, não, mas o que eu to te dizendo, talvez não tenha medo porque nunca sofri nenhum tipo de ameaça. Porque pode acontecer, né, principalmente quando a pessoa não ta com a medicação adequada, né, tudo certinho, então a gente sabe que isso pode realmente ocorrer. Já tive casos, assim, na rua, né, porque tem muito maluco andando aí pra rua, né, assim."

(Helena, Auxiliar de Enfermagem)

"Na verdade, assim, eu não tenho dificuldade, mas, assim, eu tenho um pouco de medo, às vezes..[...] eu acho que eu sempre tive uma dificuldade, assim, de lidar com o paciente... [...] Mas, assim, às vezes eu tenho um pouco de medo, sim. [...] Não que eu não goste. Aqui dá pra trabalhar tranquilo, mas talvez eu teria muita dificuldade se eu fosse trabalhar só com isso. Não assim de lidar porque eu acho que eu ia fazer um trabalho bom porque eu gosto de ouvir, eu gosto de sentar, de escutar, de ouvir, mas talvez, acho que comigo mesma eu talvez ficaria meio frustrada."

(Andreia, Auxiliar de Enfermagem)

"Eu particularmente, assim, eu acho que eu... [...] eu vejo isso... a gente, por não saber lidar, a gente se afasta, às vezes, um pouco. Né? Porque, às vezes, é aqueles problemas que, putz, não têm remédio.”

(Fernanda, Enfermeira)

"Agora, tem uma coisa boa, que é a convivência com esses pacientes, ela libera um pouco de preconceito, né? Porque antes, a gente tinha muito preconceito com paciente de saúde mental, né? Agora, como eles frequentam muito o Núcleo, etc, a equipe já se acostuma a atender, né, e, às vezes, tem até uma crise, você acostuma a identificar essas crises, né. Eles participam de grupos com a gente, né? Nós fazemos 
visitas, por exemplo, na Casa Terapêutica que tem na nossa área. [...] Eles frequentam o grupo, tanto em atividades clínicas, quando em atividades de apoio, né, de grupo. Então, eu acho que é bem razoável, sabe, assim? Do que eu via antes de começar a Saúde da Família nesse esquema, eu acho que a gente avançou muito.”

(Jorge, Médico/Coordenador)

"Foi nessa época também que eu fui trabalhar num hospital psiquiátrico, como clínico, [...] com muito receio. Loucura sempre coloca muito medo nas pessoas, né? $E$, nessa ocasião, eu fiquei muito assustado porque de repente eu tive que assumir uma enfermaria com 70 pacientes com transtorno mental pra... pra atenção clínica desses pacientes. E, aí, esse universo era muito novo pra mim e a gente vai desconstruindo aquelas coisas que ao longo da nossa formação, inclusive, nos ensinam sobre loucura, né, pelo menos na minha época. [...] E aí, a minha ligação maior, o meu envolvimento com a saúde mental foi a partir desse trabalho. Então, é muito curioso observar a dita loucura. Porque às vezes você não sabe de que lado você está, né? A gente tem as chaves entre a sanidade e a loucura, mas às vezes você chega a pensar de que lado ta a loucura, né?”

(Miguel, Médico/Coordenador)

"E diria mais, né, assim, é puro preconceito. Não precisa ser ninguém portador de transtorno mental... sujeito ficou puto, sai quebrando as coisas por aqui, né, porque a ideia é que vai vim, vai quebrar, vai agredir. E, primeiro, isso era uma coisa que eu tinha quando eu fui trabalhar no hospital psiquiátrico, 'Ah, vão me bater'. E não tem nada disso, o sofrimento é muito maior, o risco é muito maior pro doente do que pro profissional, né, isso é uma coisa que a gente desconstrói."

(Miguel, Médico/Coordenador)

"Eu fiquei meio assustado (com a ideia de realizar visitas à Casa Terapêutica). Mas com o passar do tempo e conhecendo as pessoas, eu vi que realmente... Você vê que tem uma... uma... como que eu vou te explicar... a gente é muito preconceituoso. A gente tem um receio do diferente e agora que eu to começando a conviver melhor com eles. Já entro, já brinco. Quando a cuidadora falou pra mim que um dos rapazes tinha matado o irmão, [...] eu não conseguia me aproximar dele, dessa pessoa. E eu fui começar... toda vez que eu chego lá, ele vai se arrumar, sabe, ele vai trocar de roupa, eu acho que é legal isso, pra te receber! [...] Então eu achei muito legal, então eu num... To começando a acabar com esse bloqueio que eu tinha. Que eu pus. Eu mesmo pus.”

(Geraldo, ACS)

"E aí, na reunião nossa aqui, né, [...] alguns membros da própria equipe falaram 'Ah, mas eles têm problema psiquiátrico, como que eles vão participar dos nossos grupos?' e a gente 'Ué, mas a intenção é... eles não tão morando numa casa, há dez anos, não saíram do (fala o nome de um hospital psiquiátrico de internação total)? Então! Eles são pessoas como qualquer...' E eles 'E se descompensarem?' 'Ah, gente, se descompensar, nós vamos manejar. Todo mundo não pode descompensar um dia na vida? Alguém não pode ter uma crise de ansiedade, uma crise de pânico e não ter diagnóstico nenhum? E o que que a gente vai fazer? A gente não vai acolher, não vai atender, não vai conversar? [...]'. Mas foi muito complicado porque algumas pessoas 
ficaram 'Ah, acho que não tem que vim, não pode misturar com as outras pessoas' $E$ foi uma briga grande entre equipe porque a Tereza (ACS), por exemplo, que defende, ela falou assim 'Como assim misturar com as outras pessoas? Eles são pessoas como todo mundo!'. E falaram 'Não. São pessoas especiais'. E, se você ver que aqui dentro, que a gente trabalha com isso, que a gente é acostumado, tem preconceito! Você imagina na sociedade. Você entendeu? Então, é difícil inseri-los. Não tem um programa próprio pra eles. Então, eu acho que eles são marginalizados.”

(Raquel, Médica de Família)

Os trechos das entrevistas das auxiliares de enfermagem Helena e Andreia são ilustrativos de uma compreensão das pessoas em sofrimento mental como potencialmente perigosas. Helena pontua que "talvez não tenha medo porque nunca sofreu nenhum tipo de ameaça” [sic], evidenciando uma associação entre sofrimento mental e comportamento imprevisível, duvidoso e potencialmente agressivo. Andreia refere ter "um pouco de medo" [sic] de lidar com o paciente em sofrimento mental devido a experiências anteriores durante os estágios profissionalizantes, todavia considera que desempenharia um bom trabalho de cuidado, pois gosta "de sentar, de escutar, de ouvir" [sic]. Chama a atenção que os verbos utilizados por Andreia para descrever sua prática com relação às pessoas em sofrimento mental pressupõem uma relação em que o profissional ouve e o usuário se beneficia dessa escuta, parecendo desconsiderar a possibilidade de uma relação em que ambos se beneficiem do encontro.

Fernanda, por sua vez, aponta as incertezas vivenciadas pelos profissionais diante de situações que "não têm remédio" [sic]. O posicionamento da enfermeira evidencia sua concepção de sofrimento mental e revela a lógica de cuidados centrada nos procedimentos em que cada queixa exige uma conduta e, caso contrário, não há o que ser feito e, como consequência, “a gente se afasta” [sic]. Infere-se uma compreensão reducionista da pessoa humana, através da qual o indivíduo é reduzido aos seus aspectos biológicos e esvaziado quanto aos seus desejos, interesses, expectativas, habilidades e necessidades diversas que o constituem em sua singularidade. Ao passo que, o entendimento de que as pessoas são constituídas por aspectos que vão para além do biológico parece possibilitar intervenções que transcendem o remédio ou a ausência dele. Para Pimentel, Villares e Mateus (2013), relacionar-se com o usuário de forma mais integral implica em conhecer a natureza das experiências adversas da pessoa, a extensão de suas redes sociais, sua autoimagem e outros aspectos relevantes de suas características pessoais, podendo incorporar essas questões no plano de tratamento. Segundo os autores, as doenças de longa evolução geralmente são vistas 
pelos profissionais de saúde com desconfiança e pessimismo, reduzindo a expectativa e o investimento do profissional e prejudicando o tratamento dos pacientes. Aponta-se que a crença de que pouco ou nada tem a ser feito nessas situações pode configurar uma interdição do exercício cotidiano de exploração de estratégias não medicamentosas. Assim, a impotência é atestada antes mesmo de serem pensadas e testadas alternativas de ordem psicossocial.

Para Jorge a oportunidade de convivência com as pessoas em sofrimento mental, oportunizada pelo fato dos serviços de Atenção Primária estarem localizados no território, contribui para a "liberação do preconceito" [sic]. Infere-se, assim, que a possibilidade de aproximação, de contato com o sofrimento interfere positivamente na desconstrução dos estigmas e dos processos discriminatórios. Todavia, apesar da fala do coordenador indicar e valorizar a boa convivência entre a equipe e tais "pacientes" [sic], fica evidente, ainda, tanto em sua fala, quanto nas falas de Andreia e Helena, uma cisão entre “eles” [sic] (usuários que possuem um diagnóstico de transtorno mental e precisam de cuidados) e “nós” [sic] (profissionais que despendem cuidados).

Já Miguel evidencia outra compreensão acerca da pessoa em sofrimento mental. Ao relatar a experiência de assumir uma enfermaria com setenta pacientes psiquiátricos, Miguel refere que, inicialmente, teve “muito receio" [sic], chegando a hipotetizar, inclusive, situações de agressão física: “Ah, vão me bater” [sic]. Entretanto, infere-se através de seu relato que conforme ele teve a oportunidade de conviver com tais pessoas, permitindo-se observar e entrar em contato com o sofrimento mental, foi possível abrir-se para um processo de desconstrução dos pré-conceitos instituídos até então, inclusive durante sua formação médica. Miguel demonstra, ainda, compreender o sofrimento mental como inerente à condição humana, de tal forma que quando se trata da “dita loucura” [sic], é difícil diferenciar “de qual lado você está” [sic]. De acordo com sua lógica, qualquer pessoa, independente de possuir um diagnóstico de transtorno mental, está suscetível a enfrentar variações de humor devido a situações que despertem ansiedade, raiva, tristeza e euforia, o que pode levar a comportamentos explosivos. Entretanto, é o paciente psiquiátrico quem carrega este estigma mais intensamente, o que sustenta e quase naturaliza a lógica da necessidade da contenção, do controle sobre essas pessoas e do afastamento das mesmas.

O relato de Geraldo também explicita um processo de desconstrução de preconceitos alavancado pela possibilidade de aproximação dos moradores da Casa Terapêutica. O agente relatou que se sentiu “assustado" [sic] quando soube que deveria realizar visitas domiciliares regulares a uma Casa Terapêutica. Apesar de defrontar-se com seus próprios medos e preconceitos, Geraldo permitiu-se aproximar destes moradores e, a partir dessa experiência, 
pôde resignificar sua compreensão acerca do sofrimento mental e da pessoa em sofrimento, modificando sua postura.

Raquel descreve uma situação vivenciada pela equipe durante uma reunião em que estava em discussão a participação, ou não, das pessoas com “problema psiquiátrico” [sic] nos grupos ofertados pela USF. Segundo a médica, tal discussão dividiu opiniões entre os membros da equipe, pois parte dos profissionais era contrária à participação dessas "pessoas especiais” [sic] nas atividades com os demais usuários do serviço. Raquel explicita sua compreensão acerca do sofrimento humano quando argumenta que "todo mundo pode descompensar um dia na vida" [sic], apontando que essa não é uma possibilidade exclusiva das pessoas diagnosticadas com transtornos mentais. Nesse sentido, a médica tenta desmistificar o sofrimento mental, fazendo esforços para demonstrar aos membros da equipe que os mesmos dispõem de recursos para lidar com esta demanda, por exemplo, “acolher, entender, conversar" [sic].

Esta vinheta da entrevista de Raquel, bem como as demais apresentadas, é ilustrativa do processo de transformação das posturas e práticas que vem acontecendo na área da saúde mental. Observou-se por meio das entrevistas que os profissionais da USF, por estarem alocados no território, visando o estabelecimento de parcerias contínuas com a comunidade, são frequentemente questionados ou colocados a pensar sobre as questões relativas à saúde mental, por exemplo: Quais fantasias alicerçam o medo de visitar as Casas Terapêuticas? Qual o inconveniente da participação das pessoas com diagnóstico de transtornos mentais nas atividades regulares da USF? Quais crenças perpassam o incômodo do contato com o sofrimento mental? Por que os profissionais tendem a se afastar das situações que "não têm remédio" [sic] Nesse sentido, as entrevistas revelam a diversidade de opiniões dos profissionais sobre o tema, reiterando o preconceito e o medo, resultantes de uma longa história de segregação das pessoas em sofrimento mental que ainda precisa ser revista, o que reafirma a importância dos espaços de reflexão e debate acerca das práticas e concepções em relação à saúde mental.

Frateschi e Cardoso (2014) em estudo sobre a avaliação dos usuários acerca dos cuidados em saúde mental ofertados pela Atenção Primária apontam que os usuários referem ser constantemente vítimas de preconceito e discriminação quando recorrem principalmente a serviços não especializados em saúde mental. Pimentel et al. (2013) apontam que as situações de preconceitos e discriminação vivenciadas pelos usuários podem despertar sentimentos de vergonha e baixa autoestima nos mesmos, podendo acarretar a ampliação do isolamento e comprometer a procura e adesão ao tratamento. Assim, segundo os autores, fica prejudicada a 
efetiva participação social destas pessoas em relação a questões relativas à, por exemplo, moradia, emprego, salário, saúde, culminando na sistemática exclusão social das mesmas.

Nota-se que na prática, no dia a dia dos serviços, o processo de reconhecimento do usuário para além da doença é um desafio para os profissionais, os quais ainda apresentam certa dificuldade em ampliar o olhar sobre a pessoa, de forma a enxergá-la em sua integralidade, digno de respeito, cuidado e atenção. Considerando que um dos preceitos da Reforma Psiquiátrica é a reorganização do modelo social, visando possibilitar a reconstrução da cidadania, dos direitos humanos e sociais da pessoa em sofrimento mental (Ribeiro, Ribeiro \& Oliveira, 2008), tem-se que as equipes de saúde, principalmente as da ESF, por estarem alocadas no território, configuram-se agentes importantes do processo de desconstrução de estigmas e de informação da população acerca da necessidade e da importância da inserção das pessoas em sofrimento mental no convívio das famílias e comunidades (Frateschi \& Cardoso, 2014). Entretanto, o que se observou a partir dos relatos é, ainda, certo estranhamento por parte dos profissionais com relação às pessoas em sofrimento mental, uma vez que em suas falas tal condição esteve frequentemente associada a imprevisibilidade, perigo e agressividade, mesmo que nunca se tenha enfrentado qualquer situação de risco. Infere-se, a partir das entrevistas, que aqueles profissionais que se dispuseram a entrar em contato com o sofrimento mental, defrontando-se com seus receios, pré-conceitos e preconceitos, puderam empreender um processo de questionamento e reflexão acerca de suas práticas, caminhando no sentido da desconstrução dos estigmas.

Nesse sentido, Munari et al. (2008) destacam que a formação dos profissionais de saúde é resultado de uma construção histórica e social e, para transformá-la, faz-se necessário provocar a quebra de “certezas” construídas ao longo da história. A possibilidade de aproximação do sofrimento mental, seja através de visitas domiciliares como descrito por Geraldo, ou através de discussões em equipe, como relatado por Raquel, podem constituir momentos de reflexão e reconstrução destas “certezas”, fomentando transformações nas posturas e práticas e agregando novos sentidos para os fazeres em saúde.

Compreende-se que a oferta de cuidados em saúde mental pela ESF é influenciada pelas concepções dos profissionais e usuários acerca do processo de desinstitucionalização da assistência psiquiátrica e consequente expansão da rede de serviços extra-hospitalares. As vinhetas a seguir ilustram a opinião de alguns profissionais sobre as intervenções em saúde mental tendo em vista o contexto de cuidados no território. 
"Só que eu acho que a gente ainda peca na falta de vagas, né, eu acho que saúde mental, tem muito pouco hospital psiquiátrico, assim, pelo menos para as internações agudas, não essas crônicas, institucionais. Isso, de fato, eu acho que só em casos extremos, mas, enfim, eu acho que o que faltou foi isso, né, saúde mental, você faz a maior parte ambulatorial, mas, às vezes, você sofre, porque você ta aqui na porta de entrada, paciente em surto psicótico, paciente querendo tratamento pra álcool, pra droga, você não tem aonde pôr o paciente. Fica sem vaga porque, como houve todo esse... desaparelhou, né, a parte hospitalar. Eu acho assim, eu acho que foi ótimo, eu acho que essa é a ideia, mas tem que lembrar que hospital psiquiátrico... Agora eles estão tentando 'ah, vai por em hospital geral', né, essa coisa de criar enfermarias psiquiátricas em hospitais gerais... É uma forma, talvez, de segurar [...] eu acho que ta certo, eu acho legal mas o pessoal tinha que se preocupar um pouco com isso aí... Essa parte, a hospitalização ainda é importante, principalmente pra essas crises agudas, tempo breve pra compensação do paciente. Lógico, e depois devolver ele pra família...”

(Maurício, Médico de Família)

Mara: Fernanda, e como você entende as transformações que vem acontecendo quanto ao cuidado da saúde mental? [...]

Fernanda: Ah, eu acho assim, bom, mas eu acho que a gente precisa melhorar o suporte pra esse paciente que sai. Acho que um exemplo claro é a Residência Terapêutica, né, que a gente vê que eles foram reinseridos, reinseridos entre aspas, assim, eles foram colocados, eles foram tirados do hospital. Mas eu não sei até que ponto ta trabalhando com a reinserção deles na comunidade. Eu acho que são duas coisas diferentes. Tirar do hospital e trabalhar a reinserção. [...] Se eles foram colocados numa casa que eles só convivem entre eles e não é estimulado que eles participem de coisa fora, né, falta essa outra parte. Eu acho que é estimular eles a participar de outras coisas, conviver com outras pessoas, né, dentro das limitações deles, fazer atividades dentro de casa, né, então, eu vejo assim. [...]

Mara: E você acha que isso é papel do Núcleo também?

Fernanda: Também. [...] Eu acho que isso é de co-participação. Mas eu acho que eles precisam, é, ter uma organização primeiro. Porque não adianta tirar eles de lá e... Como já aconteceu muitas vezes, né, eles não "Ah, não dá pra levar", "Ah, não dá pra ir”. Então, por exemplo, a consulta médica... Nada mais é... É uma atitude de reinserção, eles virem, como todo mundo vem e passar em consulta médica aqui. Com horário agendando, né, é a parte clínica, né? Mas o que acontece? Aí a cuidadora fala "Ah, eu não posso levar um e não levar os outros", [...] Então, eles estão ainda numa camisa de força, assim, meio moldados, entende? [...] E elas não trabalham com as individualidades. [...] Parece, assim, uma casa de cuidados, assim, sabe, de... Como se fosse um lugar pra colocar pessoas, pra juntar as pessoas e ficar. Não sei. Não sei. A gente tem sentido um pouco disso.

(Fernanda, Enfermeira)

Mara: Raquel, e qual a sua opinião sobre esse processo que vem acontecendo de transformação do cuidado da saúde mental?

Raquel: De verdade, eu acho que foi excelente. E é muito bom... eu acho que... você vê, as Casas Terapêuticas, por exemplo, nesse modelo mudando, dão super certo, né? Dão certo, os pacientes estão voltando pra sociedade, eles participam de grupos, eles participam das atividades que a gente faz aqui, das festinhas, né? Tendo como 
exemplo eles. E eu sou a favor. Eu acho que tem que ser feito isso mesmo. São pacientes muito sofridos que viveram, às vezes, 40 anos internados no (fala o nome de um hospital psiquiátrico de internação total.) E que hoje moram nas Residências há dez anos, juntos. Lá eles fazem tudo, lá eles têm a vidinha deles. [...] Então, eu acho muito interessante. E desde que eu to aqui, eles nunca tiveram uma crise. [...] Então, é como se fosse uma república, né? É bem bacana.

(Raquel, Médica de Família)

Mara: E como você acha que as propostas da Reabilitação Psicossocial podem ser viabilizadas? Visando a reinserção... a criação de espaços de troca...

Maurício: É, eu acho que para os pacientes que não tem suporte familiar, eu acho que as Casas Terapêuticas é ideal. Pros que tem, acho que o CAPS é uma forma legal de acompanhamento, né, de você ter o paciente em casa, às vezes mantendo um hospitaldia, naquele esquema de hospital-dia, eu acho que é uma forma do paciente voltar pra sociedade, ativo, né, na medida do possível. Acho que a Atenção Primária, a gente, acho que faz um serviço legal nos casos de Atenção Primária, né? O NASF se existisse também, acompanhando, né, a Atenção Primária também pra acompanhar o paciente.

(Maurício, Médico de Família)

Mara: E as propostas da Reabilitação Psicossocial, como é que você entende?

Lúcia: Então, eu acho que tem que ter as pessoas especializadas, né, que saibam mesmo trabalhar com eles. Eu não sei se a comunidade ta preparada pra isso, pra... Porque fechando o hospital psiquiátrico, não tem... Fazer o que quando a pessoa tem uma crise? Porque às vezes ela tem problema, tem crise de ideação suicida, ou de... de... outros, né, como fala? Risco, né? [...] Pra outras pessoas. E, aí, faz o que? Interna naquele momento? [...] Mas a gente vê a pessoa ali que fica 3, 4, 5 dias esperando vaga pra internação no (fala o nome do setor de Psiquiatria de um hospital geral) $E$ isso, imagina, uma pessoa que tem um transtorno, pra família, você ver, né, o filho, o marido, o parente ali, tanto tempo, ruim, esperando uma vaga. Acho que, assim, a sociedade não ta preparada pra isso, né?

(Lúcia, ACS)

As questões relativas à internação, ou não, da pessoa em sofrimento mental também dividiram as opiniões dos entrevistados. A vinheta de Maurício é ilustrativa de uma compreensão de que as internações em hospitais psiquiátricos ainda são necessárias tendo em vista a insuficiência da rede de cuidados. Maurício reconhece que a Reforma Psiquiátrica prevê que a pessoa em sofrimento mental seja cuidada em enfermarias psiquiátricas dentro de hospitais gerais, entretanto sugere que a rede substitutiva ainda está aquém da demanda, apontando para uma limitação estrutural da rede de cuidados em saúde mental, o que deixa os profissionais "sem ter aonde pôr o paciente” [sic]. Infere-se que a concepção de cuidados em saúde mental de Maurício esteja associada à lógica biomédica, na qual as intervenções em saúde mental são desenvolvidas a partir da situação dada. Assim, observa-se que, quanto mais 
a atuação estiver centrada na tentativa de resolução do problema dado, lançando mão de protocolos, mais evidente se faz a ausência de recursos físicos e de dispositivos concretos. Neste cenário nota-se então, que mesmo dentro das USFs, as estratégias de promoção e prevenção, pautadas em recursos comunitários, acabam sem espaço, esvaziadas de sentido.

Outro aspecto que se destaca nas entrevistas com os profissionais é o fato de que, frequentemente, ao se posicionarem acerca do processo de desinstitucionalização da assistência psiquiátrica, acabam por reduzi-lo a diminuição dos leitos em hospitais psiquiátricos. Os trechos das entrevistas de Fernanda e Raquel são ilustrativos desta compreensão, uma vez que ao serem interrogadas sobre suas opiniões acerca das transformações relativas aos cuidados em saúde mental, reduziram suas respostas às Casas Terapêuticas. Fernanda destaca que o processo de retirada dos pacientes do hospital não foi acompanhado de estratégias de reinserção destas pessoas na sociedade que promovessem a convivência e estimulassem as potências individuais. Ao ser interrogada sobre a participação da USF neste processo, destaca a necessidade de consolidação de uma parceria entre a Unidade de Saúde e as Casas Terapêuticas, apontando a consulta médica como uma possibilidade de reinserção social destes pacientes.

As Casas Terapêuticas, ou Serviço Residencial Terapêutico, conforme nomenclatura adotada pelo Ministério da Saúde, resultam de grande empenho, nos últimos anos, visando concretizar as diretrizes de superação do modelo de atenção centrado no hospital psiquiátrico (Ministério da Saúde, 2004b). As Casas Terapêuticas surgem como componentes da rede de atenção e como política de saúde mental do Ministério da Saúde, configurando-se alternativas de moradia para pessoas que permaneceram internadas em hospitais psiquiátricos durante longos períodos por não disporem de suporte adequado na comunidade. Ou ainda, podem servir de apoio a usuários de outros serviços de saúde mental que não possuem suporte familiar e social suficiente para garantir espaço adequado de moradia (Ministério da Saúde, 2004b; Rolin, 2013). Ainda de acordo com o Ministério da Saúde (2004b), o suporte ofertado pelas Casas Terapêuticas tem caráter interdisciplinar, podendo ter como referência um CAPS, uma equipe de Atenção Primária ou outros profissionais, devendo levar em consideração a singularidade de cada morador, objetivando a inserção do usuário na rede de serviços, organizações e relações sociais da comunidade. Assim, compreende-se que a estadia em Casas Terapêuticas deve se constituir o início de um processo de reabilitação que deverá buscar a progressiva inclusão social do morador (Ministério da Saúde, 2004b). Rolin (2013) faz a ressalva que a operacionalização da moradia assistida implica na atividade clínica de muitas formas, entretanto, ela não equivale a um tratamento. Compreende-se, portanto, sob 
esta perspectiva, que a dimensão clínica das Casas Terapêuticas não configura uma forma de tratamento, mas está articulada a ele.

Considerando este cenário, sugere-se que os profissionais apresentaram uma compreensão relativamente confusa a respeito das atribuições da Casa Terapêutica e de sua articulação com a USF. Contrariamente ao previsto pelo Ministério da Saúde, tal serviço parece ser identificado pelos participantes como um dispositivo de cuidados no território, dando ênfase a seu caráter clínico. Sob esta perspectiva, a responsabilidade da USF enquanto provedora de cuidados parece ser, equivocadamente, diminuída.

Dado o contexto da Reforma Psiquiátrica, entende-se que as Casas Terapêuticas não são representativas do caráter inovador da proposta, mas, pelo contrário, como dito anteriormente, foram estruturadas inicialmente para responder às necessidades daqueles que perderam seus laços afetivos em decorrência dos longos períodos de internação, conforme recomendava o modelo asilar. E, por meio da realização das entrevistas, observou-se que apesar da questão formulada pela pesquisadora ser suficientemente ampla, enfatizando as transformações relativas aos cuidados em saúde mental, dado os preceitos da Reabilitação Psicossocial e o contexto da Reforma Psiquiátrica, as considerações dos participantes tenderam a ficar restritas às Casas Terapêuticas, ou seja, aos dispositivos destinados à doença instalada, à loucura crônica, à dependência institucional e, consequentemente, ao modelo asilar. Evidencia-se, assim, uma reflexão pouco amadurecida acerca das atribuições da ESF enquanto arranjo inovador que orienta os cuidados em saúde no âmbito da Atenção Primária, capaz de atuar sobre os cuidados em saúde mental sob a perspectiva da desinstitucionalização, priorizando o cuidado no território a partir de ações mais conectadas com o cotidiano das pessoas.

Nesse sentido, chama a atenção o fato de nas falas dos profissionais os mesmos não fazerem referência aos casos de sofrimento mental que estão na comunidade, fora de Casas Terapêuticas e que nunca passaram por internações. Esta compreensão parece embasar a crença de que, apesar da grande demanda que os serviços recebem, há pouco a ser feito no âmbito da Atenção Primária quanto à saúde mental, uma vez que as Casas Terapêuticas dão assistência aos egressos de hospitais psiquiátricos e os CAPS assumem os casos mais sérios que eventualmente se manifestam, conforme destacado por Lúcia e Maurício. Trata-se de um indício de que a atuação dos profissionais ainda permanece bastante associada à doença. Apesar de os participantes expressarem uma valorização das mudanças e um desejo, no âmbito do discurso, de avançar em novas formas de fazer saúde, mais abrangentes e integrais, superando o uso mecânico dos procedimentos, na prática ainda há pouco investimento em 
ações de promoção de saúde, voltadas à comunidade, que transcendam a lógica queixaconduta.

Infere-se que esse processo de transformação das práticas esteja atrelado, primeiramente, a uma mudança de olhar sobre o sofrimento mental, de modo que este seja compreendido como parte integrante da vida, atravessado por aspectos concretos do cotidiano. Busca-se a desnaturalização das estratégias de controle e vigilância sobre a pessoa em sofrimento mental para que, assim, possam ser desveladas novas possibilidades de arranjos a serem estabelecidos entre serviço e comunidade, pautados na consolidação de parcerias que, através da construção conjunta de projetos de vida, priorizem o exercício da liberdade e a legitimação de um lugar social. 
CONSIDERAÇÕES FINAIS 



\section{CONSIDERAÇÕES FINAIS}

Este trabalho objetivou conhecer e compreender as ações desenvolvidas pela Estratégia Saúde da Família no que se refere à Reabilitação Psicossocial em saúde mental, a partir da perspectiva dos profissionais de saúde da ESF, dos usuários em sofrimento mental e de seus familiares. As entrevistas possibilitaram que os participantes expressassem suas compreensões sobre as necessidades em saúde mental, as ações voltadas para este cuidado, as experiências de contato com o sofrimento mental e as dificuldades encontradas nos processos de trabalho. Conforme se pronunciaram sobre os temas propostos através de relatos de casos específicos, ou mesmo, de reflexões sobre as práticas cotidianas, os entrevistados também avaliaram o cuidado em saúde mental ofertado/recebido e explicitaram suas concepções acerca da pessoa em sofrimento mental, dos processos de cuidado e das transformações das práticas decorrentes da Reforma Psiquiátrica e das políticas de fortalecimento da Atenção Primária. Considera-se que tais concepções são determinantes das posturas e práticas instituídas, tanto por profissionais quanto por usuários e familiares, diante das situações de sofrimento mental.

Foi frequente nas falas dos participantes a associação entre sofrimento mental e periculosidade/imprevisibilidade, mesmo que nunca tivessem enfrentado qualquer situação de risco decorrente do contato com o sofrimento mental. Acredita-se que as equipes da ESF, por estarem próximas às famílias e comunidades, podem assumir importante papel, junto à população, no processo de desmistificação da loucura e combate ao preconceito, todavia, observou-se que sentimentos de medo e insegurança ainda estão presentes nos próprios profissionais. A partir dos relatos, notou-se que aqueles profissionais que puderam se aproximar do sofrimento mental, questionando seus próprios medos e preconceitos, puderam empreender um processo de reflexão sobre suas posturas e práticas, abrindo-se para novas experiências de contato.

Observou-se que o sofrimento mental possui estreita relação com aspectos do contexto no qual se insere. Deste modo, considerando a complexidade das situações vivenciadas e os princípios que norteiam a atuação das equipes da ESF, acredita-se que seja de grande importância que as ações mais pontuais, como as consultas e a medicalização, estejam permanentemente associadas a uma série de outras estratégias, no âmbito da atenção psicossocial, que possibilitem o acompanhamento do usuário em seu percurso de significação dos sintomas e de busca por melhores condições de vida. O Ministério da Saúde (2005b) 
aponta que quanto mais o sofrimento for compreendido e correlacionado com a vida, menos oportunidade haverá de se tornar um problema somente do serviço de saúde. Tenciona-se, assim, a oferta de intervenções mais abrangentes e conectadas ao cotidiano, compreendendo o sofrimento mental como intrínseco à condição humana, atravessado pelas circunstâncias contextuais e relacionais estabelecidas pelas pessoas.

Nesta mesma direção, corroborando com o pressuposto de que o sofrimento mental compõe a vida das pessoas, bem como a vida em comunidade, as entrevistas evidenciaram o tênue limite entre saúde e doença. Assim, ao entrevistar as familiares com o intuito de conversar a respeito da convivência com o outro em sofrimento mental, investigando possíveis situações de sobrecarga e estratégias de cuidado, deparou-se com pessoas que também tinham o próprio sofrimento para relatar. A partir disso, este estudo apontou que a compreensão ampliada do cuidado pode provocar desdobramentos importantes nas práticas em saúde tais como o entendimento de que o sofrimento mental permeia os percursos de vida, independente de diagnósticos, o que referenda o desenvolvimento de estratégias mais abrangentes.

Durante a realização das entrevistas, os participantes se referiram a ações que contribuem direta ou indiretamente para a promoção, preservação e recuperação da saúde mental. Sobre esse tópico observou-se que frequentemente os procedimentos, tais como consultas, encaminhamentos, internação e medicalização, foram referidos pelos entrevistados como estratégias centrais dos processos de cuidados em saúde mental. Como consequência, foi observada uma intensa valorização do conhecimento especializado, atribuindo ao médico, e principalmente ao psiquiatra, o lugar de saber e a responsabilidade por conduzir os casos de sofrimento mental. Esta compreensão reforça a lógica de trabalho em saúde centrada no especialismo e na compartimentação da pessoa a partir das áreas do saber, de forma que as queixas são associadas a condutas específicas, agrupando sob o mesmo rótulo todos os que apresentam determinada condição.

Nesse contexto, de acordo com o Ministério da Saúde (2005b), torna-se necessária uma mudança de olhar, que busque saber além do que a pessoa apresenta de "igual”, o que ela apresenta de "diferente”, de singular. A partir desta perspectiva, desvela-se outra lógica de cuidado, centrada na pessoa e em suas necessidades, por meio da qual as consultas, medicações e psicoterapias são compreendidas como ferramentas importantes dentro de um processo mais amplo de busca por melhores condições de vida. Nesse cenário, as equipes da ESF ganham lugar de destaque por estarem inseridas nos territórios e se proporem a acompanhar os moradores ao longo das diferentes etapas da vida. Assim, abre-se a 
possibilidade dos profissionais entrarem em contato e se apropriarem do contexto real no qual se inserem as famílias e as comunidades. Dessa forma, aspectos do contexto e aspirações concretas podem integrar as práticas em saúde, de maneira que a atuação dos serviços de saúde não fique restrita ao abrandamento do sofrimento, mas possa abarcar também as questões que o atravessa, por exemplo: conflitos familiares, situações de violência, solidão, falta de emprego ou de moradia. Espera-se, deste modo, que o usuário acione o serviço para cuidar de seu projeto de vida e que a equipe possa acompanhá-lo, integrando este projeto, mobilizando recursos e firmando parcerias com outros equipamentos sociais.

Sob um novo paradigma, em que é proposta a superação do modelo biológico, centrado na psicopatologia, e o avanço em práticas psicossociais, centradas na pessoa em sofrimento e na comunidade, observou-se que os profissionais têm realizado esforços para assumirem uma postura de escuta, de acolhimento, legitimando o sofrimento. Todavia, estas ações ainda são colocadas em prática, principalmente, de forma individual, durante as consultas e visitas domiciliares. Apesar de relatarem um desejo de desenvolver alternativas de cuidado mais horizontais e integrais, voltadas para o coletivo, os profissionais revelaram um sentimento de impotência frente ao sofrimento mental, como se não possuíssem, ou desconhecessem, as ferramentas necessárias para atuarem. As estratégias coletivas referidas pelos participantes, em geral, ficam restritas a grupos promovidos pela própria USF visando à promoção de saúde e/ou à veiculação de informações sobre determinadas práticas e condições, como amamentação, obesidade, hipertensão e diabetes. Infere-se que apesar dos participantes demonstrarem reconhecer as potencialidades contidas na convivência comunitária, valorizando estratégias mais horizontais e dialógicas, tem-se que os grupos ainda são pensados e efetivados sem a participação da comunidade, conformando-se, assim, como mais um procedimento do qual a equipe lança mão.

Para Pinto et al. (2012), os serviços de saúde são organizados a partir dos riscos e vulnerabilidades da composição físico-orgânica da vida humana e, consequentemente, as demandas de saúde da população permanecem atreladas ao déficit patológico do viver, ou seja, aos agravos, doenças e crises. Assim, as redes assistenciais são interpostas visando responder às enfermidades e reprimir as crises, reduzindo o espectro da prevenção e promoção em saúde e abrindo espaço para intervenções pautadas na hospitalização e na coerção, mantendo, no caso da saúde mental, a condição de psiquiatrizado do usuário.

Quanto ao preparo para o contato com o sofrimento mental, os profissionais fizeram referência tanto às experiências anteriores (profissionais e de formação) quanto às práticas de qualificação para o trabalho em saúde mental no contexto da ESF. Os relatos evidenciaram 
que a formação proporcionada tanto por cursos técnicos quanto por cursos universitários tende a enfatizar os aspectos clínicos do sofrimento mental, colocando, conforme aponta Basaglia (1982, citado por Amarante, 2009), o sujeito entre parênteses para ocupar-se da doença, em detrimento de uma formação humana voltada para o contato com o outro em sofrimento, colocando a doença entre parênteses para ocupar-se do sujeito em sua experiência. Observou-se por meio dos relatos que a formação profissional, frequentemente, se pauta em estratégias que visam o aprimoramento das habilidades de identificação e manejo do sofrimento mental, encontrando respaldo numa lógica em que a pessoa em sofrimento mental precisa ser controlada devido a sua periculosidade e inconstância. Nesse sentido, o estudo apontou que apesar de no âmbito do discurso os profissionais valorizarem práticas mais dialógicas e horizontais, ainda observa-se a permanência do preconceito e do medo em relação à pessoa em sofrimento mental.

Supõe-se, a este respeito, que a formação profissional tem muito a contribuir para o processo de desmistificação da loucura. E, ainda, considerando que a falta de suporte psicológico e a necessidade de preparo técnico foram apontadas como algumas das dificuldades cotidianas encontradas pelos profissionais para o contato com o sofrimento mental, infere-se que dado o contexto da ESF, parece adequado que os trabalhadores da saúde sejam capacitados, por meio de momentos de estudo e reflexão sobre as práticas, para exercer uma postura de abertura para o outro, valendo-se de empatia e criatividade para a consolidação de parcerias e arranjos que levem em conta as vivências, limites, habilidades e aspirações dos atores envolvidos.

Conforme aponta Basaglia (1991, citado por Minozzo \& Costa, 2013) a escuta dos casos de sofrimento mental pelos profissionais da Atenção Primária, antes do encaminhamento para serviços especializados, favorece a colocação da crise em uma perspectiva histórica, tornando mais conscientes o paciente e seus familiares e explicitando as contradições e os conflitos que se mobilizam neste momento de vida. Assim, desvela-se a possibilidade de compreensão do sofrimento mental dentro de um contexto múltiplo e diverso, em detrimento de um entendimento da loucura como condição de “desrazão” que assola um indivíduo descolado de história e contexto, sob o qual recai propriamente o peso do sofrimento.

Quanto à avaliação dos entrevistados acerca das práticas em saúde mental desempenhadas pela ESF, tem-se que sob a perspectiva clínica tradicional do cuidado, os serviços foram avaliados como adequados, intervindo por meio de acolhimento, medicalização e encaminhamento das queixas. Sob a perspectiva do modelo psicossocial, 
levando em consideração os relatos dos entrevistados sobre o maior investimento nos vínculos, em estratégias coletivas e na escuta qualificada das demandas dos usuários, tem-se que, apesar de tímidos, alguns passos estão sendo dados em direção à consolidação de formas de cuidado mais abrangentes e contextualizadas. Este estudo evidenciou que os profissionais, em geral, são capazes de identificar as necessidades em saúde mental dos usuários, para além das demandas referidas, como por exemplo, necessidade de contato humano e de compartilhar as situações vivenciadas. Todavia, os profissionais revelaram-se inseguros e impotentes diante de tais situações, o que pode indicar que as questões apresentadas pelos usuários, de alguma maneira, são representativas de seus próprios desconfortos e dúvidas perante a vida.

Ishara e Cardoso (2013) apontam que a sociedade consolidada no mundo contemporâneo é marcada pela competitividade, desvalorização do ser humano e fragilidade nos relacionamentos interpessoais. Evidencia-se uma compreensão reducionista do humano, ignorando um amplo horizonte de aspirações, necessidades e potencialidade próprias de sua natureza. Diante deste cenário, conformam-se frágeis redes de suporte social, marcadas pelas limitadas possibilidades de interação e de desenvolvimento de vínculos, em meio à desconfiança sobre o outro e a crença na autossuficiência, configurando rotinas de vida solitárias. Colocando em questão o papel dos profissionais da saúde frente a este contexto, compreendendo-os enquanto membros integrantes desta mesma cultura, sujeitos às mesmas pressões, infere-se que a possibilidade de assumir a postura de "não saber”, colocando-se ao lado do outro para a construção compartilhada dos caminhos trilhados, constitui tanto oportunidade de elaboração e experimentação de práticas transformadoras, quanto um alívio da cobrança sobre os profissionais por soluções prontas que visem à redução do sofrimento.

A este respeito, Pelbart (1990) pondera que:

[...] não basta acolher os loucos ou relativizar a noção de loucura compreendendo seus determinantes psicossociais, como se a loucura fosse só distúrbio e sintoma social, espécie de ruga que o tecido social, uma vez devidamente 'esticado' através de uma revolucionária plástica sócio-política, se encarregaria de abolir. (p. 134)

Assim, o autor faz a proposta de, para além da libertação das pessoas institucionalizadas, deve-se libertar também os manicômios mentais, nos quais confina-se a “desrazão”. Desvela-se, assim, a possibilidade do exercício do pensar, considerando novas formas de lidar com fatores como o acaso, o desconhecido e o improvável, evitando a mecanização das rotinas e favorecendo o uso da invenção e do improviso diante do incógnito. Desta forma, depreende-se que a superação do paradigma asilar e os avanços visando à 
consolidação de sociedades mais solidárias e tolerantes não se conformam como garantias de supressão do sofrimento mental, mas devem estar associados aos processos de desmistificação da loucura enquanto uma condição desviante de determinado padrão de normalidade.

Visando não perder de vista o sofrimento concreto dos usuários que recorrem cotidianamente às USFs, este trabalho se propôs a discutir as atribuições do especialista em saúde mental no âmbito da Atenção Primária, na forma em que aparece no contexto estudado, ou seja, a Consultoria Psiquiátrica. A julgar pela avaliação dos entrevistados, tem-se que este recurso foi considerado como importante ferramenta tanto de cuidado em saúde, quanto de preparo dos profissionais para o trabalho em saúde mental. A partir da compreensão deste espaço como uma possibilidade de aproximação do trabalho do especialista, observou-se que a ênfase da proposta recai sobre capacitar os profissionais com curso superior da ESF para identificação e manejo dos casos de sofrimento mental, tendo sido pouco referido o uso deste espaço para o desenvolvimento de ações mais amplas e comunitárias de promoção de saúde mental. Concluiu-se, portanto, que a Consultoria Psiquiátrica, enquanto um passo anterior ao apoio matricial, constitui um recurso potente e inovador de cuidados em saúde mental, todavia, observou-se a centralidade do saber especializado nestes espaços, o que parece estar associado à lógica de hierarquia dos saberes e de atuação sobre o sintoma.

Sugere-se que a Consultoria Psiquiátrica, ao se propor a acompanhar os casos de sofrimento mental selecionados pelas equipes, presta relevante trabalho ao auxiliar os profissionais da USF quanto ao manejo das situações. Todavia, ainda faz-se necessário aprimorar as estratégias relacionais, onde caibam a negociação, a dúvida e o fazer compartilhado, viabilizando processos de significação do sofrimento e a maior participação dos usuários no âmbito do que lhe diz respeito.

Este estudo pôde evidenciar um processo em curso de transformação das práticas em saúde a partir do questionamento das posturas instituídas no que se refere à desinstitucionalização da assistência psiquiátrica. Ao menos no âmbito do discurso, pôde ser observada a incorporação das propostas da Reforma Psiquiátrica e da Reabilitação Psicossocial, associadas aos princípios e diretrizes do Sistema Único de Saúde. Nesse sentido, evidencia-se um período de transição, pois ao mesmo tempo em que são notados avanços em direção a uma compreensão do sofrimento mental enquanto uma condição humana, as possibilidades de intervenção sobre tal situação ainda permanecem muito associadas ao saber especializado. Ressalta-se que a insuficiência da lógica biomédica, pautada na especialização dos saberes, torna-se especialmente evidente quando se refere aos cuidados em saúde mental no âmbito da ESF, uma vez que a conduta médica responde parcialmente às queixas, 
intervindo sobre o alívio dos sintomas, sendo destituída de potência de ação sobre os contextos e relações que podem estar interferindo ou determinando o sofrimento.

Considera-se que o processo de transformação das práticas em saúde é lento e configura um trabalhoso desafio diante do qual os profissionais se posicionam cotidianamente. Desse modo, frente à observação de que não existem receitas ou modelos prontos de ação quando se trata de sujeitos e comunidades singulares, infere-se que o avanço em estratégias transformadoras esteja atrelado ao exercício contínuo de reflexão sobre as atribuições dos serviços de saúde e de experimentações de novas práticas, bem como de atenção e questionamento dos processos de trabalhos, das relações estabelecidas e das posturas referendadas diariamente.

Dado este cenário, considera-se que este estudo propõe reflexões e traz avanços relativos à viabilização das práticas de cuidado em saúde mental no território visando o comprometimento com a pessoa em seu percurso de vida. Neste sentido, foi enfatizada a importância de incluir o usuário no âmbito das decisões daquilo que lhe diz respeito, incorporando suas necessidades e aspirações nos projetos terapêuticos e, mais do que isso, atribuindo-lhe voz para que contribua com o desenvolvimento de estratégias em saúde, avalie as práticas desempenhadas pelo serviço e sugira ações direcionadas a pessoas que estejam enfrentando situação semelhante à sua. Sugeriu-se a integração dos familiares nos processos de construção dos projetos terapêuticos, pois mais do que uma fonte de suporte, a família tem potencial para contribuir com aquilo que conhece do usuário a partir da convivência, além de agregar informações advindas de suas próprias vivências. Tendo em vista os relatos dos profissionais sobre o sentimento de impotência e falta de preparo para lidar com o sofrimento mental, sugeriu-se a criação e/ou apropriação de espaços dentro da rotina de trabalho visando à reflexão sobre os processos de cuidado, incluindo a discussão sobre as crenças e valores que atravessam as questões relativas à saúde mental, oportunizando a construção de sentidos sobre as atribuições do serviço de saúde frente a esta demanda. Ainda nesta direção, indicou-se a possibilidade do profissional assumir um lugar de "não saber", colocando-se ao lado da pessoa em sofrimento na busca por melhores condições de vida.

Quanto ao lugar do saber especializado, sugeriu-se que os alunos, residentes ou aprimorandos, desempenhassem mais ações junto aos profissionais, num movimento de troca de saberes, na tentativa de fortalecer a equipe para a atuação frente às questões que cotidianamente se apresentam aos serviços. No que diz respeito à Consultoria Psiquiátrica, levantou-se a hipótese de que a participação dos agentes comunitários e auxiliares de enfermagem nos momentos de discussão dos casos poderia contribuir para melhor 
compreensão da equipe das situações experienciadas pelos usuários devido a informações trazidas por estes profissionais e, ainda, favorecer o rompimento de estigmas e preconceitos devido à possibilidade de maior aproximação dos mesmos com as questões relativas ao sofrimento mental.

Quanto à articulação dos serviços em rede e considerando que frequentemente um mesmo usuário recorre a diferentes equipamentos, sugeriu-se a elaboração de projetos terapêuticos unificados para cada usuário de forma que cada equipe ou profissional atue complementarmente aos demais, o que pode favorecer que o usuário se mantenha acompanhado ao longo de seu percurso pelos serviços de saúde. Ainda neste sentido, enfatizou-se a importância dos projetos terapêuticos abarcarem os aspectos concretos da vida das pessoas, como moradia, emprego, renda, conflitos familiares, entre outros, de forma que o usuário recorra ao serviço para tratar de seu plano de vida. E, assim, destacou-se a posição estratégica das equipes da ESF que, por atuarem junto ao território, podem desenvolver ações de promoção de saúde que favoreçam a convivência comunitária, como festas, feiras, bazares, oficinas de recreação (dança, ginástica, cinema) ou capacitação (informática, trabalhos manuais), associações com cooperativas de trabalho e com outros equipamentos sociais, desenvolvendo práticas intersetoriais.

Vale ressaltar que através destas propostas pretendeu-se avançar em ideias e reflexões que possam fortalecer os processos de desinstitucionalização da assistência psiquiátrica, buscando alternativas às práticas tradicionais que frequentemente são reproduzidas de forma mecanizada.

Como limitação do presente estudo, considera-se que o mesmo representa um recorte da situação da oferta de ações de saúde mental no âmbito da Estratégia Saúde da Família, circunscrito ao contexto de duas Unidades de Saúde da Família de uma cidade de médio porte do interior do estado de São Paulo. Apesar disso, acredita-se que as entrevistas com os profissionais, usuários e familiares oportunizaram um olhar sobre o cuidado em saúde mental no contexto da ESF, apontando algumas reflexões que se pretendem úteis para a efetivação de ações em saúde mais conectadas às necessidades comunitárias e sociais, tomando o cuidado em saúde mental como uma ação transversal do serviço de saúde, que perpassa todas as práticas. O estudo evidenciou o potencial dos profissionais, usuários e familiares de se posicionarem criticamente frente ao tema, demonstrando a importância da participação dos diferentes atores nos processos de planejamento, efetivação e avaliação de políticas e práticas de saúde. 
Novos estudos são necessários visando ampliar as questões abordadas, inclusive, transpondo-as para a prática dos serviços e, nesta perspectiva, sugere-se avançar na realização de pesquisas sobre: estratégias de avaliação dos cuidados em saúde mental ofertados pela Atenção Primária que levem em conta o processo saúde/doença do usuário e do território; a qualificação dos profissionais tendo em vista sua formação humana; a apropriação pela população tanto dos espaços comunitários que compõem o território quanto dos espaços de participação e controle social; estratégias de melhor articulação entre ações e serviços de diferentes setores, visando à consolidação de práticas mais abrangentes. Considera-se que a continuidade dos estudos acerca das práticas em saúde mental ofertadas pela Atenção Primária à Saúde oportuniza o avanço em relação às estratégias psicossociais, e também, a consolidação de uma sociedade mais solidária com as diferenças, defendendo-as enquanto direitos sociais. 
REFERÊNCIAS 



\section{REFERÊNCIAS}

Alverga, A. R., \& Dimenstein, M. D. B. (2006). A reforma psiquiátrica e os desafios na desinstitucionalização da loucura. Interface - Comunicação, Saúde, Educação, 10(20), 299-316. doi: 10.1590/S1414-32832006000200003

Alves, D. S., \& Guljor, A. P. (2005). O Cuidado em Saúde Mental. In R. Pinheiro, \& R. A. Mattos (Orgs). Cuidado: As fronteiras da integralidade. (2a ed., pp. 221-240). Rio de Janeiro, RJ: CEPESC/UERJ, ABRASCO.

Alves, P. A. L. (2011). Vida social de usuários de um CAPS: a reconstrução de subjetividades. Dissertação de Mestrado, Universidade de São Paulo, Ribeirão Preto, SP, Brasil.

Amarante, P. D. C., \& Giovanella L. (1994). O enfoque estratégico do planejamento em saúde mental. In P.D.C. Amarante (Org.). Psiquiatria Social e Reforma Psiquiátrica. Rio de Janeiro, RJ: Fiocruz.

Amarante, P. D. C. (1995). Novos sujeitos, novos direitos: O debate em torno da Reforma Psiquiátrica. Cadernos de Saúde Pública, 11(3), 491-494. doi: 10.1590/S0102311X1995000300024

Amarante, P. D. C. (2009). Reforma Psiquiátrica e Epistemologia. Cadernos Brasileiros de Saúde Mental, 1(1), 1-7. Recuperado de http://incubadora.periodicos.ufsc.br/index .php/cbsm/article/view/998

Arce, V. A. R., Sousa, M. F., \& Lima, M. G. (2011). A práxis da Saúde Mental no âmbito da Estratégia Saúde da Família: contribuições para a construção de um cuidado integrado. Physis: Revista de Saúde Coletiva, 21(2), 541-560. doi: 10.1590/S010373312011000200011

Ayres, J. R. C. M. (2000). Cuidado: tecnologia ou sabedoria prática. Interface - Comunicação, Saúde, Educação, 4(6), 117-120. doi: 10.1590/S1414-32832000000100010

Ayres, J. R. C. M. (2004). Cuidado e reconstrução das práticas de saúde. Interface, 8(14), 7392. doi: 10.1590/S1414-32832004000100005

Bardin, L. (2011). Análise de conteúdo (Ed. rev.). Lisboa: Edições 70. (Trabalho original publicado em 1977). 
Brêda, M. Z., Rosa, W. A. G., Pereira, M. A. O., \& Scatena, M. C. M. (2005). Duas estratégias e desafios comuns: a reabilitação psicossocial e a saúde da família. Revista Latino-Americana de Enfermagem, 13(3), 450-452. doi: 10.1590/S010411692005000300021

Caçapava, J. R., Colvero, L. A., Martines, W. R. V., Machado, A. L., Silva, A. L. A., Vargas, D., Oliveira, M. A. F., \& Barros, S. (2009). Trabalho na atenção básica: integralidade do cuidado em saúde mental. Revista da Escola de Enfermagem da USP, 43(2), 12561260. doi: 10.1590/S0080-62342009000600019

Camargo-Borges, C. (2002). Sentidos de saúde/doença produzidos numa comunidade alvo do Programa de Saúde da Família (PSF). Dissertação de Mestrado, Universidade de São Paulo, Ribeirão Preto, SP, Brasil.

Camargo-Borges, C., \& Cardoso, C. L. (2005). A Psicologia e a Estratégia de Saúde da Família: compondo saberes e fazeres. Psicologia \& Sociedade, 17(2), 26-32. doi: 10.1590/S0102-71822005000200005

Camargo-Borges, C. (2007). O Construcionismo Social no contexto da Estratégia Saúde da Família: Articulando saberes e práticas. Tese de Doutorado, Universidade de São Paulo, Ribeirão Preto, SP, Brasil.

Campos, R. O., Gama, C. A., Ferrer, A. L., Santos, D. V. D., Stefanello, S., Trapé, T. L., \& Porto, K. (2011). Saúde mental na atenção primária à saúde: estudo avaliativo em uma grande cidade brasileira. Ciência \& Saúde Coletiva, 16(12), 4643-4652. doi: 10.1590/S1413-81232011001300013

Camuri, D., \& Dimenstein, M. D. B. (2010). Processos de trabalho em saúde: práticas de cuidado em saúde mental na Estratégia Saúde da Família. Saúde e Sociedade, 19(4), 803-813. doi: 10.1590/S0104-12902010000400008

Carvalho, A. L., \& Amarante, P. D. C. (1996). Avaliação de qualidade dos novos serviços de saúde mental: Em busca de novos parâmetros. Saúde em Debate, (52), 74-82. Recuperado de http://docvirt.com/asp/acervo_cebes.asp?Bib=SAUDEDEBATE\& PASTA $=$ N.52+-+set.+1996\&pesq $=\& x=12 \& y=19$

Constituição da República Federativa do Brasil de 1988. (1988). Brasília. Recuperado de http://www.planalto.gov.br/ccivil_03/constituicao/constitui\%C3\%A7ao.htm

Costa-Rosa, A. (2000). O modo psicossocial: um paradigma das práticas substitutivas ao modo asilar. In P. Amarante (Org). Ensaios: subjetividade, saúde mental, sociedade. (pp. 141-168). Rio de Janeiro: Fiocruz. 
Delfini, P. S. S., Sato, M. T., Antoneli, P.P., \& Guimarães, P. O. S. (2009). Parceria entre CAPS e PSF: o desafio da construção de um novo saber. Ciência e Saúde Coletiva, 14(1), 1483-1492. doi: 10.1590/S1413-81232009000800021

Delgado, J. M., \& Gutiérrez, J. (1995). Teoría de la observación. In J. M. Delgado, \& J. Gutiérrez (Coords). Métodos y técnicas cualitativas de investigación em ciencias sociales. Madrid: Ed. Sinteses.

Dimenstein, M. D. B. (1998). O Psicólogo nas Unidades Básicas de Saúde: desafios para a formação e atuação profissionais. Estudos em Psicologia. 3(1), 53-81. doi: 10.1590/S1413-294X1998000100004

Dimenstein, M. D. B. (2004). A Reorientação da Atenção em Saúde Mental. Psicologia Ciência e Profissão, 24(4), 112-117. doi: 10.1590/S1414-98932004000400013

Dimenstein, M. D. B., Severo, A. K., Brito, M., Pimenta, A. L., Medeiros, V., \& Bezerra, E. (2009). O apoio matricial em Unidades de Saúde da Família: experimentando inovações em saúde mental. Saúde e Sociedade, 18(1), 63-74. doi: 10.1590/S010412902009000100007

Federación Española de Asociaciones de Rehabilitación Psicosocial. (2010). Declaración de Valladolid. Trabajo presentado en el Terceiro Congreso de la Federación Española de Asociaciones de Rehabilitación Psicosocial (FEARP); Segunda Conferencia Europea de la World Association for Psychosocial Rehabilitation (WAPR). Valladolid, España.

Figueiredo, M. D., \& Campos, R. O. (2009). Saúde Mental na atenção básica à saúde de Campinas, SP: uma rede ou um emaranhado? Ciência \& Saúde Coletiva, 14(1), 129138. doi: 10.1590/S1413-81232009000100018

Fiorati, R. C., \& Saeki, T. (2012). Projeto terapêutico nos serviços extra-hospitalares de saúde mental: uma reflexão crítica sobre a forma de elaboração e gestão dos projetos terapêuticos nos serviços. Saúde e Sociedade, 21(3), 587-598. doi: 10.1590/S010412902012000300006

Franco, T. B., \& Merhy, E. E. (2012). Cartografias do Trabalho e Cuidado em Saúde. Revista Tempus - Actas de Saúde Coletiva, 6(2), 151-63. Recuperado de http://www.tempus. unb.br/index.php/tempus/article/view/1120/1034

Frateschi, M. S., \& Cardoso, C. L. (2014). Saúde Mental na Atenção Primária à Saúde: avaliação sob a ótica dos usuários. Physis: Revista de Saúde Coletiva, 24(2), 545-565. doi: 10.1590/S0103-73312014000200012 
Gonçalves, D. A. (2013). Saúde Mental na Atenção Básica: o matriciamento. In M. D. Mateus (Org), Políticas de saúde mental. (pp. 124-138). São Paulo, SP: Instituto de Saúde.

Heidemann, I. T. S. B. (2006). A promoção da saúde e a concepção dialógica de Freire: possibilidades de sua inserção e limites no processo de trabalho das equipes de Saúde da Família. Tese de Doutorado, Universidade de São Paulo, Ribeirão Preto, SP, Brasil.

Instituto Brasileiro de Geografia e Estatística. (2010). Censo 2010. Recuperado de http://www.ibge.gov.br

Ishara, S., \& Cardoso, C. L. (2013). Delineamento do Grupo Comunitário de Saúde Mental. In S. Ishara, C. L. Cardoso \& S. R. Loureiro (Orgs), Grupo Comunitário de Saúde Mental: Conceito, Delineamento Metodológico e Estudos. (pp. 19 - 40). Ribeirão Preto, SP: Nova Bonfim Editora.

Jaegger, R. C., Guitton, A. P., Lyrio, J. M., Santos, M. M., Freitas, R. C. O., Gonçalves, S. R., ... Legay, L. F. (2004). A experiência de morar fora: avaliação de satisfação de usuários em um serviço de saúde mental. Cadernos Saúde Coletiva, 12(1), 27-39. Recuperado de http://www.cadernos.iesc.ufrj.br/cadernos

Jorge, M. S. B., Sousa, F. S. P., \& Franco, T. B. (2013). Apoio matricial: dispositivo para resolução de casos clínicos de saúde mental na Atenção Primária à Saúde. Revista Brasileira de Enfermagem, 66(5), 738-744. doi: 10.1590/S0034-71672013000500015

Lancetti, A. (2001). Síntese Metodológica. In A. Lancetti (Coord.), Saúde Loucura 7: Saúde Mental e Saúde da Família. (pp. 117-120). São Paulo: Hucitec.

Leão, A. (2006). As práticas de inclusão social: o desafio para os serviços de saúde mental. Dissertação de Mestrado, Universidade de São Paulo, São Paulo, SP, Brasil.

Lei Nº 8080 de 17 de setembro de 1990. (1990). Dispõe sobre as condições para a promoção, proteção e recuperação da saúde, a organização e o funcionamento dos serviços correspondentes e dá outras providências. Brasília. 1990. Recuperado de http://www. planalto.gov.br/ccivil_03/leis/l8080.htm

Lei No. 8.142, de 28 de dezembro de 1990. (1990). Dispõe sobre a participação da comunidade na gestão do Sistema Único de Saúde (SUS) e sobre as transferências intergovernamentais de recursos financeiros na área da saúde e dá outras providências. Brasília. 1990. Recuperado de http://www.planalto.gov.br/ccivil_03/leis/l8142.htm. 
Lei. N ${ }^{0}$. 5972, de 23 de abril de 1991. (1991). Dispõe sobre a participação da comunidade na gestão do sistema único de saúde em Ribeirão Preto e dá outras providências. Ribeirão Preto. 1991. Recuperado de http://cm.jusbrasil.com.br/legislacao/688783/lei-5972-91

Lei N ${ }^{o}$. 10.216, de 06 de abril de 2001. (2001). Dispõe sobre a proteção e os direitos das pessoas portadoras de transtornos mentais e redireciona o modelo assistencial em saúde mental. Brasília. 2001. Recuperado de http://www.planalto.gov.br/ ccivil_03/leis/leis_2001/l10216.htm

Luz, M. T. (2001). Políticas de Descentralização e Cidadania: Novas Práticas em Saúde no Brasil Atual. In R. Pinheiro, \& R.A. Mattos (Orgs), Os sentidos da integralidade da atenção e no cuidado à saúde. (3a ed., pp. 17-39). Rio de Janeiro, RJ: UERJ, IMS: ABRASCO.

Mateus, M. D. (2013a). O Centro de Atenção Psicossocial (CAPS). In M. D. Mateus (Org), Políticas de saúde mental. (pp. 139-158). São Paulo, SP: Instituto de Saúde.

Mateus, M. D. (2013b). Princípios dos cuidados de saúde mental na comunidade. In M. D. Mateus (Org), Políticas de saúde mental. (pp. 92-107). São Paulo, SP: Instituto de Saúde.

Mattos, R. A. (2001). Os sentidos da integralidade: algumas reflexões acerca de valores que merecem ser defendidos. In R. Pinheiro, \& R.A. Mattos (Orgs). Os sentidos da integralidade da atenção e no cuidado à saúde. (3a ed., pp. 39-64). Rio de Janeiro, RJ: UERJ, IMS: ABRASCO.

Mendes, E. V. (2011). As Redes de Atenção à Saúde. (2a ed.). Brasília: Organização PanAmericana de Saúde.

Merhy, E. E. (2000). Um ensaio sobre o médico e suas valises tecnológicas: contribuições para compreender as reestruturações produtivas do setor saúde. Interface Comunicação, Saúde, Educação, 4(6), 109-116. doi: 10.1590/S141432832000000100009

Mielke, F. B., Cossetin, A., \& Olschowsky, A. (2012). O Conselho Local de Saúde e a Discussão das Ações de Saúde Mental na Estratégia Saúde da Família. Texto \& Contexto Enfermagem, 21(2), 387-394. doi: 10.1590/S0104-07072012000200017

Minayo, M. C. S. (2004). O Desafio do Conhecimento - Pesquisa Qualitativa em Saúde. (8a ed). São Paulo : Hucitec. (Trabalho original publicado em 1992).

Minayo, M. C. S. (2012). Análise qualitativa: teoria, passos e fidedignidade. Ciência e Saúde Coletiva 17(3), 621-626. doi: 10.1590/S1413-81232012000300007 
Ministério da Saúde. (1986). VIII Conferência Nacional de Saúde. Brasília: Centro de Documentação do Ministério da Saúde.

Ministério da Saúde. Portaria No 9.925, de 13 de novembro de 1998. (1998, 13 de novembro). Aprova o Manual para Organização da Atenção Básica no Sistema Único de Saúde. Diário Oficial da União, seção 1.

Ministério da Saúde. (2000). Programa Saúde da Família. (Cadernos de Atenção Básica, Vol. 1). Brasília, DF: Ministério da Saúde.

Ministério da Saúde. Portaria No 336, de 19 de fevereiro de 2002. (2002, 20 de fevereiro). Estabelece que os Centros de Atenção Psicossocial poderão constituir-se nas seguintes modalidades de serviços: CAPS I, CAPS II e CAPS III, definidos por ordem crescente de porte/complexidade e abrangência populacional. Diário Oficial da União, seção 1.

Ministério da Saúde. (2004a). Saúde Mental no SUS: Os Centros de Atenção Psicossocial. Brasília.

Ministério da Saúde. (2004b). Residências Terapêuticas: o que são, para que servem. Brasília.

Ministério da Saúde. (2005a). Conferência regional de reforma dos serviços de saúde mental: 15 anos depois de Caracas, Reforma Psiquiátrica e política de saúde mental no Brasil. Brasília.

Ministério da Saúde. (2005b). Clínica Ampliada e Compartilhada. Política Nacional de Humanização da Gestão do SUS. Brasília.

Ministério da Saúde. (2010). Diretrizes do NASF (Núcleos de Apoio à Saúde da Família). (Cadernos de Atenção Básica, Vol. 27). Brasília, DF: Ministério da Saúde.

Ministério da Saúde. (2012a). Diretrizes e normas regulamentadoras de pesquisa envolvendo seres humanos. Resolução n ${ }^{\circ}$ 466/12 do Conselho Nacional de Saúde. Brasília.

Ministério da Saúde. (2012b). Política Nacional de Atenção Básica. Brasília.

Ministério da Saúde. (2012c). Saúde mais perto de você - Acesso e Qualidade. Programa Nacional de Melhoria do Acesso e da Qualidade Da Atenção Básica (PMAQ). Brasília. 
Ministério da Saúde. (2013). Saúde mental (Cadernos de Atenção Básica, Vol. 34). Brasília, DF: Ministério da Saúde.

Ministério da Saúde. (s.d.). Departamento de Atenção Básica. Recuperado de http://dab.saude.gov.br/atencaobasica.php

Minozzo, F., Kammzetser, C. S., Debastiani, C., Fait C. S., \& Paulon, S. M. (2012). Grupos de saúde mental na Atenção Primária à Saúde. Fractal, 24(2), 323-340. doi: 10.1590/S1984-02922012000200008

Minozzo, F., \& Costa, I. I. (2013). Apoio matricial em saúde mental entre CAPS e Saúde da Família: trilhando caminhos possíveis. Psico-USF, 18(1), 151-160. doi: 10.1590/S1413-82712013000100016

Munari, D. B., Melo, T. S., Pagotto, V., Rocha, B. S., Soares, C. B., \& Medeiros, M. (2008). Saúde Mental no contexto da atenção básica: potencialidades, limitações, desafios do Programa de Saúde da Família. Revista Eletrônica de Enfermagem, 10(3), 784-795. Recuperado de http://www.fen.ufg.br/revista/v10/n3/v10n3a24.htm

Nicácio, M. F. (1989). Da instituição negada à instituição inventada. In A. Lancetti, A. C. Cesarino, S. Yasui, P. Mascarenhas, I. Marazinha, M. F. Nicácio, \& G. Baremblitt (Orgs.), Saúde loucura 1 (pp. 91-108). São Paulo, SP: Hucitec.

Nunes, M., Jucá, V. J., \& Valentim, C. P. B., (2007). Ações de saúde mental no Programa de Saúde da Família: confluências e dissonâncias das práticas com os princípios das reformas psiquiátrica e sanitária. Cadernos de Saúde Pública, 23(10), 2375-2384. doi: 10.1590/S0102-311X2007001000012

Oliveira, F. B., \& Silva, A. O. (2000). Enfermagem em saúde mental no contexto da reabilitação psicossocial e da interdisciplinaridade. Revista Brasileira de Enfermagem, 53(4), 584-592. doi: 10.1590/S0034-71672000000400013

Onocko-Campos, R. T., Passos, E., Palombini, A. L., Santos, D. V. D., Stefanello, S., Gonçalves, L. L. M., ... Borges, L. R. (2013). A gestão autônoma da medicação: Uma intervenção analisadora de serviços em saúde mental. Ciência \& Saúde Coletiva, 18(10), 2889-2898. doi: 10.1590/S1413-81232013001000013

Organização Mundial da Saúde. (2001). Relatório sobre a saúde no mundo. Saúde mental: nova concepção, nova esperança. Recuperado de http://www.dgs.pt/upload/membro. id/ficheiros/i006020.pdf

Paim, J. S. (2007). Reforma Sanitária brasileira: contribuição para a compreensão e crítica. Tese de Doutorado. Universidade Federal da Bahia, Salvador, BA, Brasil. 
Pegoraro, R. F. (2007). Receber e prover cuidados: a trajetória de uma mulher em sofrimento psíquico. Tese de Doutorado, Universidade de São Paulo, Ribeirão Preto, SP, Brasil.

Pelbart, P. P. (1990). Manicômio Mental: a outra face da clausura. In A. Lancetti (Org), Saúde Loucura. . $^{\circ}$ 2. (pp.131-138) São Paulo: Editora Hucitec.

Pimentel, F. A., Villares, C. C., \& Mateus, M. D. (2013). Estratégias de combate ao estigma na saúde mental. In. M. D. Mateus (Org), Políticas de saúde mental. (pp. 306-321). São Paulo, SP: Instituto de Saúde.

Pini, J. S., \& Waidman, M. A. P. (2012). Fatores interferentes nas ações da equipe da Estratégia Saúde da Família ao portador de transtorno mental. Revista da Escola de Enfermagem da USP, 46(2), 372-379. doi: 10.1590/S0080-62342012000200015

Pinto, A. G. A., Jorge, M. S. B., Vasconcelos, M. G. F., Sampaio, J. J. C., Lima, G. P., Bastos, V. C., \& Sampaio, H. A. C. (2012). Apoio matricial como dispositivo do cuidado em saúde mental na atenção primária: olhares múltiplos e dispositivos para resolubilidade. Ciência \& Saúde Coletiva, 17(3), 653-660. doi: 10.1590/S141381232012000300011

Pitta, A. M. F. (2001). O que é reabilitação psicossocial no Brasil, hoje? In A. M. F. Pitta (org.). Reabilitação psicossocial no Brasil. (2a ed.). São Paulo: Hucitec.

Prefeitura Municipal de Ribeirão Preto. (2013). Plano Municipal de Saúde 2014-2017. Recuperado de www.ribeiraopreto.sp.gov.br

Prefeitura Municipal de Ribeirão Preto (s.d.) Secretaria Municipal de Saúde. Relação de telefones, endereços, gerentes e responsáveis pelas UBDS'S, UBS'S e Unidades Especializadas. Recuperado de http://www.ribeiraopreto.sp.gov.br/ssaude/rede/i16 relacao-tel-end.php

Pupin-Andrade, V. M. (2013), O trabalho do Agente Comunitário de Saúde: concepções de profissionais e usuários. Tese de Doutorado, Universidade de São Paulo, Ribeirão Preto, SP, Brasil.

Quinderé, P. H. D., Jorge, M. S. B., Nogueira, M. S. L., Costa, L. F. A., \& Vasconcelos, M. G. F. (2013). Acessibilidade e resolubilidade da assistência em saúde mental: a experiência do apoio matricial. Ciência \& Saúde Coletiva, 18(7), 2157-2166. doi: 10.1590/S1413-81232013000700031

Randemark, N. F. R. (2009). Reabilitação psicossocial de pessoas com transtorno mental no contexto da reforma psiquiátrica brasileira: Representações das famílias. Tese de Doutorado, Universidade de São Paulo, São Paulo, SP, Brasil. 
Reinaldo, A. M. S. (2008). Saúde mental na atenção básica como processo histórico de evolução da psiquiatria comunitária. Escola Anna Nery Revista de Enfermagem, 12(1), 173-178. doi: 10.1590/S1414-81452008000100027

Rey, F. G. (2005), Pesquisa qualitativa e Subjetividade. Os processos de construção da informação. São Paulo: Thomson.

Ribeiro, C. C., Ribeiro, L. A., \& Oliveira, A. G. B. (2008). A construção da assistência à saúde mental em duas unidades de saúde da família de Cuiabá-MT. Cogitare Enfermagem, 13(4), 548-557. Recuperado de file://C:/Users/Administrador/ Downloads/13115-43493-1-PB.pdf

Ribeiro, L. M., Medeiros, S. M., Albuquerque, J. S., \& Fernandes, S. M. B. A. (2010). Saúde mental e enfermagem na estratégia saúde da família: como estão atuando os enfermeiros? Revista da Escola de Enfermagem da USP, 44(2), 376-382. doi: 10.1590/S0080-62342010000200019

Rolin, M. G. (2013). A questão da moradia em saúde mental. In M. D. Mateus (Org), Políticas de saúde mental. (pp. 169-175). São Paulo, SP: Instituto de Saúde.

Rosa, W. A. G., \& Labate, R. C. (2005). Programa de Saúde da Família: A construção de um novo modelo de assistência. Revista Latino-Americana de Enfermagem, 13(6), 10271034. doi: 10.1590/S0104-11692005000600016

Rotelli, F. (2000). Empresa Social: Construindo sujeitos e direitos. In P. D. C. Amarante (Org.) Ensaios: subjetividade, saúde, sociedade. Rio de Janeiro, RJ: Fiocruz.

Santos, J. Q. (2013). O componente social da doença mental. In M. D. Mateus (Org), Políticas de saúde mental. (pp. 204-217). São Paulo, SP: Instituto de Saúde.

Saraceno, B. (2001). Reabilitação psicossocial: Uma estratégia para a passagem do milênio. In A. M. F. Pitta (Org), Reabilitação psicossocial no Brasil. (2a ed.). (pp. 13-26). São Paulo: Hucitec.

Schimith, M. D., \& Lima, M. A. D. S. (2004). Acolhimento e vínculo em uma equipe do Programa de Saúde da Família. Cadernos de Saúde Pública, 20(6), 1487-1494. doi: 10.1590/S0102-311X2004000600005

Silva, M. A., \& Vieira, M. A. M. (2008). Saúde Mental na Atenção Básica: Reflexões sobre a Articulação do Centro de Atenção Psicossocial com o Programa de Saúde da Família. Revista Mineira de Enfermagem, 12(2), 263-269. Recuperado de http://www.enf. ufmg.br/site_novo/modules/mastop_publish/?tac=134 
Silva, N. H. L. P. (2011). Saúde Mental na Estratégia Saúde da Família: Uma compreensão a partir da Fenomenologia de Edith Stein. Tese de Doutorado, Universidade de São Paulo, Ribeirão Preto, SP, Brasil.

Silva, N. H. L. P., \& Cardoso, C. L. (2013). Contribuições da fenomenologia de Edith Stein para a atuação do psicólogo nos Núcleos de Apoio à Saúde da Família (NASF). Revista Latinoamericana de Psicopatologia Fundamental, 16(2), 246-259. doi: 10.1590/S1415-47142013000200005

Souza, A. J. F., Matias, G. N., Gomes, K. F. A., \& Parente, A. C. M. (2007). A Saúde Mental no Programa de Saúde da Família. Revista Brasileira de Enfermagem, 60(4), 391-395. doi: 10.1590/S0034-71672007000400006

Souza, J., Almeida, L. Y., Veloso, T. M. C., Barbosa, S. P., \& Vedana, K. G. G. (2013). Estratégia de Saúde da Família: recursos comunitários na atenção à saúde mental. Acta Paulista de Enfermagem, 26(6), 594-600. doi: 10.1590/S0103-21002013000600014

Tahan-Santos, E. (2011). Estratégia Saúde da Família: Satisfação de usuários. Dissertação de Mestrado, Universidade de São Paulo, Ribeirão Preto, SP, Brasil.

Tanaka, O. Y., \& Ribeiro, E. L. (2009). Ações de Saúde Mental na Atenção Básica: Caminho para Ampliação da Integralidade da Atenção. Ciência e Saúde Coletiva, 14(2), 477486. doi: 10.1590/S1413-81232009000200016

Vasconcelos, C. M., \& Pasche, D. F. (2006) O Sistema Único de Saúde. In G. W. S. Campos, M. C. S. Minayo, M. Akerman, M. Drumond \& Y. M. Carvalho (Orgs.). Tratado de Saúde Coletiva. Rio de Janeiro, RJ: Hucitec/Fiocruz.

Waidman, M. A. P., Costa, B., \& Paiano, M. (2012). Percepções e atuação do Agente Comunitário de Saúde em saúde mental. Revista da Escola de Enfermagem da USP, 46(5), 1170-1177. doi: 10.1590/S0080-62342012000500019

Wetzel, C., \& Kantorski, L. P. (2004). Avaliação de serviços em saúde mental no contexto da Reforma Psiquiátrica. Texto \& Contexto Enfermagem, 13(4), 593-598. doi: 10.1590/S0104-07072004000400012

World Health Organization. (1978). Declaration of Alma Ata. Paper presented at the International Conference on Primary Health Care. Alma Ata, Cazaquistão. Recuperado de http://bioeticaediplomacia.org/wp-content/uploads/2013/10/alma-ata.pdf

World Health Organization. (1986). Ottawa Charter for health promotion. Paper presented at the First International Conference on Health Promotion. Ottawa, Canadá. Recuperado de http://www.who.int/healthpromotion/conferences/previous/ottawa/en/ 
APÊNDICES 



\title{
APÊNDICES
}

\section{Apêndice A - Termo de Consentimento Livre e Esclarecido}

\author{
TERMO DE CONSENTIMENTO LIVRE E ESCLARECIDO
}

Você está sendo convidado para participar voluntariamente do estudo intitulado "Reabilitação Psicossocial e Estratégia Saúde da Família: Desafios no cuidado à Saúde Mental”, a ser realizado pela psicóloga mestranda Mara Soares Frateschi, orientada pela Prof. ${ }^{a}$ Dr. ${ }^{a}$ Carmen Lúcia Cardoso, docente da Faculdade de Filosofia Ciências e Letras de Ribeirão Preto da Universidade de São Paulo (FFCLRP - USP).

O objetivo deste estudo é conhecer as ações desenvolvidas pela Estratégia Saúde da Família no que se refere ao processo de Reabilitação Psicossocial em saúde mental, a partir do ponto de vista das diferentes pessoas envolvidas neste contexto: profissionais da saúde da Estratégia Saúde da Família, usuários em sofrimento mental e seus respectivos familiares.

A Reabilitação Psicossocial é um processo que busca desenvolver possibilidades da pessoa em sofrimento mental viver em comunidade, realizando trocas afetivas e materiais. Assim, a Estratégia Saúde da Família tem se apresentado como um local privilegiado para o cuidado da saúde mental, uma vez que atua próximo às famílias e comunidades, valorizando a relação entre os profissionais e os usuários, atuando de acordo com lógica da promoção de saúde. Desta forma, a realização deste estudo é relevante, pois pretende contribuir para o desenvolvimento de novas maneiras de pensar e fazer saúde, de forma a valorizar os diferentes aspectos da vida das pessoas e compreender as singularidades e necessidades especiais de cada um.

Para participar deste estudo você deve estar ciente que sua participação é voluntária e se dará através de uma entrevista que será realizada nos serviços de saúde no caso dos profissionais e nos domicílios no caso dos usuários e familiares. A entrevista é individual e terá duração aproximada de 01 hora. Serão abordados temas relacionados ao cuidado à saúde mental, por exemplo, dificuldades encontradas para o cuidado da saúde mental, avaliação do cuidado recebido/oferecido, compreensão acerca dos recursos disponíveis para o cuidado da saúde mental.

Sua identidade não será revelada publicamente e seu nome será omitido ao final do trabalho. A entrevista será áudio gravada com seu consentimento e seu conteúdo será transcrito para que seja utilizado nas futuras publicações dos resultados deste estudo.

Não há nenhum risco previsível em participar deste estudo e você é livre para desistir da participação no trabalho em qualquer momento, por qualquer motivo, sem que isso implique em qualquer prejuízo, tendo suas informações inutilizadas.

Você deverá assinar duas cópias deste Termo de Consentimento, devendo ficar com uma delas e devolver a outra à pesquisadora que deverá arquivá-la.

Você não terá nenhum gasto ao participar deste estudo, portanto, não haverá nenhuma forma de reembolso de dinheiro.

Para esclarecimentos referentes aos aspectos éticos em pesquisa, contatar:

Comitê de Ética em Pesquisa da Faculdade de Filosofia, Ciências e Letras de Ribeirão Preto - USP

Avenida Bandeirantes, 3900 - bloco 3 - sala 16 - CEP: 14040-901, Ribeirão Preto - SP - Brasil

Fone: (16) 3602-4811 / Fax: (16) 3633-2660

E-mail: coetp@ffclrp.usp.br 
Qualquer dúvida com relação a sua participação poderá ser esclarecida antes, durante e após a realização do estudo, tanto com a pesquisadora quanto com a professora que o orienta este estudo, Prof. ${ }^{a}$ Dr. ${ }^{a}$ Carmen Lúcia Cardoso, que poderá ser encontrada no endereço:

Faculdade de Filosofia, Ciências e Letras de Ribeirão Preto - FFCLRP

Departamento de Psicologia - Bloco 5 sala 33A

Av. Bandeirantes, ${ }^{\circ}$ 3900, CEP: 14040-901, Ribeirão Preto

Fone: (16) 3602-3660

Obrigada pela sua atenção e colaboração!

$\mathrm{Eu}$, aceito participar voluntariamente do presente estudo.

Ribeirão Preto, de de 2013.

\section{ASSINATURA DO PARTICIPANTE}

\section{Mara Soares Frateschi \\ Mestranda \\ (16) 8142-2677}

\author{
Prof. a Dr. ${ }^{\text {a }}$ Carmen Lúcia Cardoso \\ Docente responsável
}

(16) 3602-3660 


\section{Apêndice B - Roteiro Orientador da Entrevista com os Profissionais}

Nome: Idade:

Profissão: Tempo de atuação:

Data:

Questão disparadora: Você pode me contar sobre sua atuação com relação aos usuários com queixa de sofrimento mental?

\section{Temas a serem abordados:}

1. Avaliação que o profissional faz da assistência em saúde mental oferecida pela Unidade de Saúde da Família;

2. Avaliação que o profissional faz da sua atuação frente a casos de sofrimento mental;

3. Compreensão acerca dos recursos disponíveis para o cuidado à saúde mental, tanto no serviço, quanto na família e na comunidade;

4. Compreensão das dificuldades encontradas no que tange ao cuidado de pessoas em sofrimento mental;

5. Recursos que podem ser encontrados na comunidade e no serviço de saúde que visem o resgate da cidadania, a garantia de direitos e o respeito às singularidades. 


\section{Apêndice C - Roteiro Orientador da Entrevista com os Usuários}

Nome:

Idade:

\section{Escolaridade:}

Profissão:

\section{Grau de parentesco do familiar:}

Data:

Questão disparadora: Você pode me contar sobre suas experiências em relação à sua saúde mental?

\section{Temas a serem abordados:}

1. Compreensão do percurso do usuário em seu processo saúde/doença;

2. Compreensão das dificuldades enfrentadas cotidianamente;

3. Experiências de convívio na família, na comunidade em geral e na Unidade de Saúde da Família;

4. Avaliação que o usuário faz da assistência em saúde mental oferecida pela Unidade de Saúde da Família;

5. Percepção do espaço que ocupa na família e na comunidade;

6. Avaliação dos espaços de convívio e de troca disponibilizados pela família, pelo serviço de saúde e pela comunidade. 
Apêndice D - Roteiro Orientador da Entrevista com os Familiares

Nome:

Idade:

Escolaridade:

Profissão:

Grau de parentesco com o usuário:

Data:

Questão disparadora: "Você por me contar sobre sua experiência de convívio com (nome do usuário)?”.

\section{Temas a serem abordados:}

1. Compreensão das relações estabelecidas entre usuário e familiar, visando uma compreensão mais ampla da dinâmica familiar;

2. Compreensão das dificuldades encontradas no que tange ao cuidado da saúde mental;

3. Avaliação da assistência em saúde mental oferecida pela Unidade de Saúde da Família;

4. Compreensão acerca dos recursos disponíveis para o cuidado à saúde mental;

5. Recursos que podem ser encontrados na comunidade e no serviço de saúde que visem o resgate da cidadania, a garantia de direitos e o respeito às singularidades dos usuários em sofrimento mental. 
ANEXOS 



\title{
ANEXOS \\ Anexo A - Ofício de manifestação de concordância da instituição coparticipante (Secretaria Municipal de Saúde de Ribeirão Preto)
}

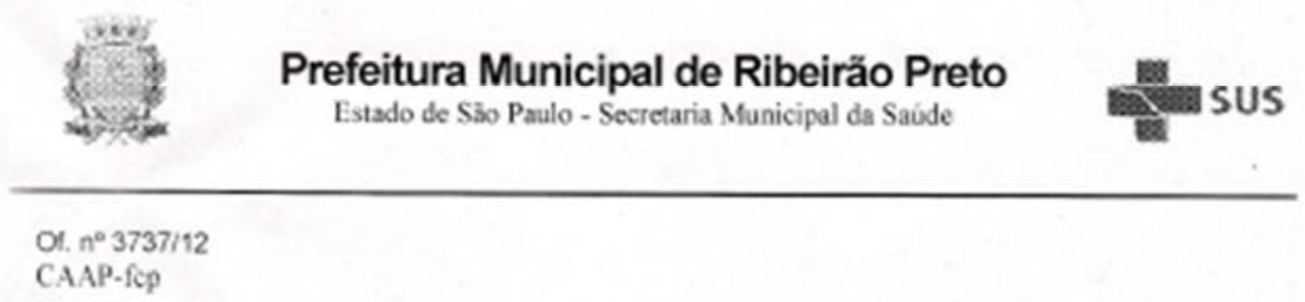

Ribeirào Preto, 04 de setembro de 2012.

\author{
Prezads crientadora. \\ Prof. Or. Cámen Lúcia Cardoso \\ Prezada pesquisadora, \\ Mara Soares Frateschi
}

A diretora do Departamento de Atençào à Saúde das Pessoss - llka Barbosa Pegoraro: manifestou a concordancia de que a coleta de dados do projeto de pesquisa -REABILITAÇÃO PSICOSSOCIAL E ESTRATÉGIA SAÚdE DA FAMILIA: DESAFIOS NO CUIDADO A SAÚdE MENTAL", nas dependèncias desta Secretaria da Ssúde. Como o seu campo do pesquisa se dara nos Nücleos de Saúde de Famila

- NSF III - Profa. Ora. Céla de Almeida Ferreira

- NSF V - Profa. Dra. Vera Holoisa Pileggi Vinna

Ressatamos que vossa senhoria se apresente aे coordenaçäo destes Núcleos com antecedéncia para agendamento da pesquisa, tendo em vista as rotinas destes estabelecimentos de saúde.

Conforme despschos no Processo Administrativo 0220120403893.

Informo que a pesquisa somente poderá hiciar quando obtiver a aprovação do Comite de Ética em Pesquisa da instituicăo proponente e a concordáncia da SUS-RP como instituiçøo coparticipante.

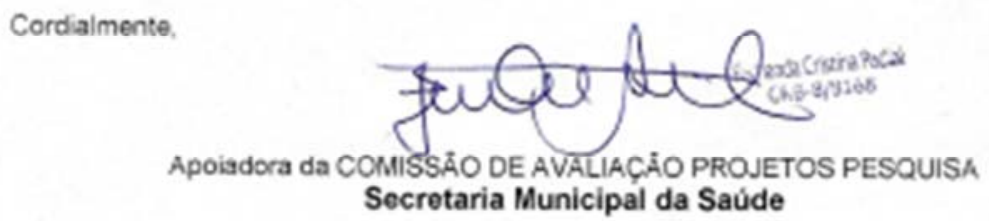

Secretaria Municioul da soude

Rus Prudente de Morass, 457 - Centro - Bibeira Preto/sp

Fones: 3977.9306 / Fax: 3941.4934 / e-mail: gobinetedssude.pmrp.com.br 
Anexo B - Parecer consubstanciado do Comitê de Ética em Pesquisa da FFCLRP-USP

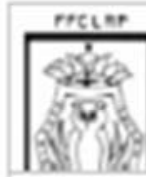

\section{FACULDADE DE FILOSOFIA, CIEENCIAS E LETRAS DE RIBEIRÃO PRETO- USP}

\section{PARECER CONSUBSTANCIADO DO CEP}

\section{DADOS DO PRQIETO DE PESQUISA}

Titulo da Pesquisa: Reablitaçato Psicossoclat e Estratega Saude da Familla: Desanos no culdado a saude mental.

Pesquisador: Mara Saares Frateschl

Area Tematica:

Versao: 3

CAAE: 057307128.0000 .5407

Instutulça Proponente: Faculdade de Flosona, Clenclas e Letras de Rbeirdo Preto- USP

Patrocinador Principal: Financiamento Proprio

DADOS DO PARECER

Numero do Parecer: 198.784

Data da Relatorla: 28022013

Apresentaça do Projeto:

Voe relato anterior.

Objetivo da Pesqulsa:

Vode relato anterior.

Avallaç30 dos Riscoe $\theta$ Benenclos:

Vide relato anterior.

Comentarios $\theta$ Consideraçoes sobre a Pesqulsa:

Voe relato anterior.

Conalderapoes acbre $\propto 8$ Termos de apresentaçao obrigatorla:

Conderando o novo modelo de Termo apresentado pela pesquisadora, considerase, agora, que o mesmo e daro e preciso o suncente: seu conteudo e redaçalo criam as condiçles necessarias, em termo etcos, a0s partcipantes para que de fato apreendam em que consiste a pesquisa e, assim decidir conscientimente pela sua participaça ou naso.

Recomendacoes:

Sugro aprovacto do Projeto, pelo Comtie.

Conclusoes ou Pendenclas $\theta$ Lata de inadequacoes:

Sugiro a aprovaç50, considerando-se que as recomendaçbes fetas pelo comve de Etica foram acatadas pelo pesquisador.

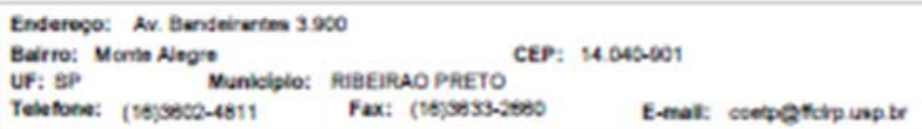




\begin{tabular}{|c|c|}
\hline ming & $\begin{array}{l}\text { FACUULDADE DE FILOSOFIA, } \\
\text { CIÊNCIAS E LETRAS DE } \\
\text { RIBEIRÃO PRETO- USP }\end{array}$ \\
\hline
\end{tabular}

Situaçao do Parecer:

Aprovado

Noceseita Apreclaç30 da CONEP:

N5o

Considerspoes Finals a criterio do CEP:

RUBEIRAO PRETO, 18 de Fevereiro de 2013

Asainador por:

Andrela Schmict

(Coorden3dor)

Enderego: Av. Bendeirertes 3900

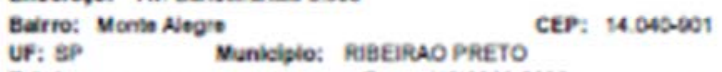

Telefore: (te)gece-4811 Fax: (tejsess-3ts6s E-mat: esetpetcipuaptr 